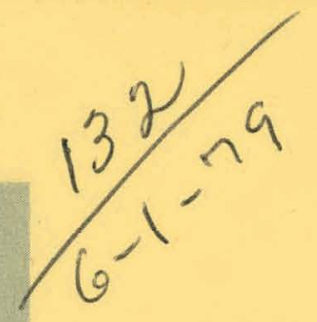

\title{
REGIONAL REFERENCE ENERGY SYSTEMS: ELECTRIC UTILITY APPLICATIONS
}

\author{
Alan Hermelee
}

January 1979

\section{TECHNOLOGY ASSESSMENT GROUP}

NATIONAL CENTER FOR ANALYSIS OF ENERGY SYSTEMS

BROOKHAVEN NATIONAL LABORATORY ASSOCIATED UNIVERSITIES, INC.

UNDER CONTRACT NO. EY-76-C-02-0016 WITH THE

UNITED STATES DEPARTMENT OF ENERGY 


\section{DISCLAIMER}

This report was prepared as an account of work sponsored by an agency of the United States Government. Neither the United States Government nor any agency Thereof, nor any of their employees, makes any warranty, express or implied, or assumes any legal liability or responsibility for the accuracy, completeness, or usefulness of any information, apparatus, product, or process disclosed, or represents that its use would not infringe privately owned rights. Reference herein to any specific commercial product, process, or service by trade name, trademark, manufacturer, or otherwise does not necessarily constitute or imply its endorsement, recommendation, or favoring by the United States Government or any agency thereof. The views and opinions of authors expressed herein do not necessarily state or reflect those of the United States Government or any agency thereof. 


\section{DISCLAIMER}

Portions of this document may be illegible in electronic image products. Images are produced from the best available original document. 


\title{
REGIONAL REFERENCE ENERGY SYSTEMS: ELECTRIC UTILITY APPLICATIONS
}

\author{
Alan Hermelee
}

January 1979

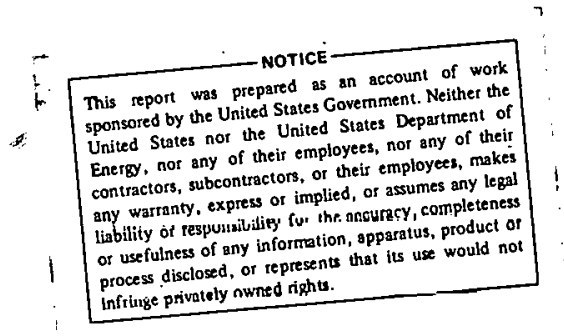

TECHNOLOGY ASSESSMENT GROUP

NATIONAL CENTER FOR ANALYSIS OF ENERGY SYSTEMS
BROOKHAVEN NATIONAL LABORATORY UPTON, NEW YORK 11973


This icport wao prepared as an arrnunt of work sponsored by the United States Government. Neither the United States nor the United States Department of Encrgy (DOE), nor any of their employees, nor any of their contractors, subcontractors, or their employees, makes any warranty, express un iniplicd, or assumes nny legal liability or reoponsibility for the accuracy, completeness or usefulness of any information, apparatus, product or process disclosed, or represents that its use would not infrimge privately owned rights. ... $:$

Printed in the United States of America Available from

National Tcchnical Information Servire.

U.S. Department of Commerce 5285 Port Royal Road Springfield, VA 22161

$\because \quad \therefore \quad$ : Price: Printed Copy $\$ 6.50$; Microfiche $\$ 3: 00$ 
Reference Energy Systems have been developed for the region serviced by the Tennessee Valley Authority for the base year 1975 and projections developed for the years 1980,1985 , and 2000. This systems formulation has traditionally been applied to the assessment of energy technologies and policies on a national level. This paper presents a reformulation of the projection methodology in order to apply the Reference Energy Systems format to an electric utility region (e.g., the Tennessee Valley Authority). The Reference Energy System is a network representation of the technical activities required to supply various forms of energy to enduse activities. Technologies are defined for all operations involving specific fuels including resource extraction, refinement, conversion, transportation, distribution, and utilization. Each of these activities is represented by a link in the network for a given year with the levels of energy demand and supply specified.

A unique advantage of using the system presented here for utility planning is its integrative view of the entire energy system as opposed to an analysis limited exclusively to the electric sector. This systems approach, incorporating all resources, technologies and uses of energy, allows a utility to assess the impact of alternate technologies and policies across the entire energy system. Demand patterns for twenty-five end-use demand categories within the residential, commercial, industrial, and transportation sectors are developed for a base case scenario representing reasonable energy use patterns derived in a consistent manner by applying engineering techniques to the best available information. The impact of a new technology in terms of resource consumption may be evaluated by modifying the energy flow paths to incorporate the new technology. Alternate paths through the network reflect the substitutability of resources and technologies for one another. 
THIS PAGE

WAS INTENTIONALLY

LEFT BLANK 


\section{ACKNOWLEDGEMENT}

The author wishes to express his appreciation to the many people at the Tennessee Valley Authority who have provided data for this study. Special thanks are owed to Ms. Joanne Swanson and Dr. Philip Kazemersky of TVA's Energy Research Group for successfully coordinating the TVA data gathering effort. Dr. Lynn Maxwell of the Division of Power Utilization has been invaluably helpful in providing electric power demand projections for the region. The Division of Power Resource Planning ab1y provided power supply projections for the TVA service area.

The contributions of Ms. Donna Visone and Susan White DePace in typing and coordinating the assembly of this document are gratefully acknowledged. 
THIS PAGE

WAS INTENTIONALLY

LEFT BLANK 


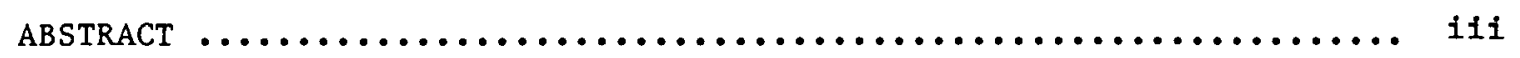

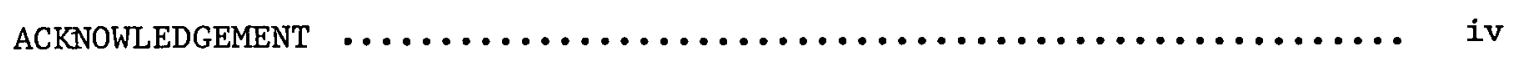

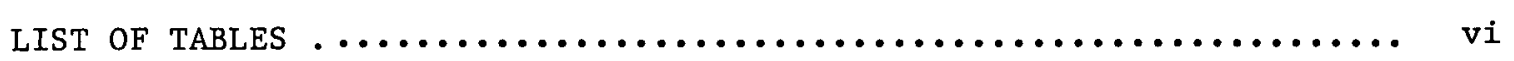

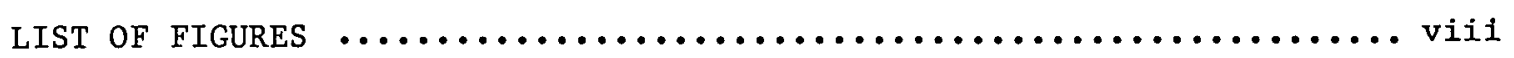

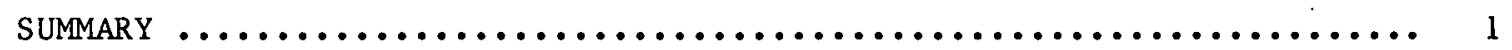

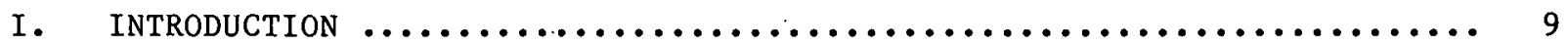

II. ENERGY DEMAND IN THE TVA REGION - METHODOLOGY $\ldots \ldots \ldots \ldots \ldots \ldots \ldots \ldots \ldots \ldots 15$

Residential Sector $\ldots \ldots \ldots \ldots \ldots \ldots \ldots \ldots \ldots \ldots \ldots \ldots \ldots \ldots \ldots \ldots \ldots \ldots \ldots$

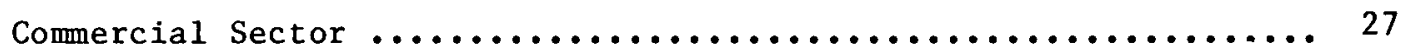

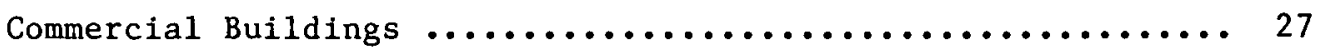

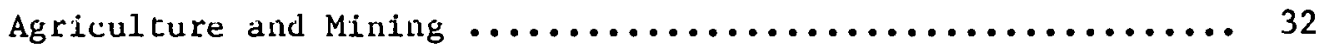

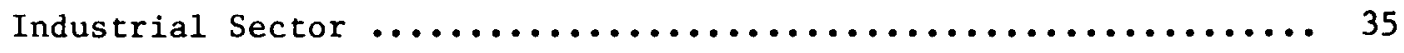

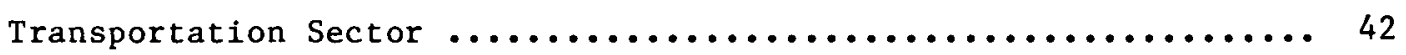

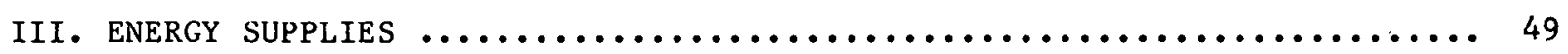

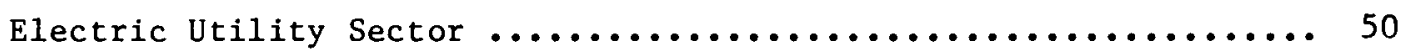

IV. TVA REFERENCE ENERGY SYSTEMS $\ldots \ldots \ldots \ldots \ldots \ldots \ldots \ldots \ldots \ldots \ldots \ldots \ldots \ldots \ldots \ldots$

The Evaluation of New Technologies $\ldots \ldots \ldots \ldots \ldots \ldots \ldots \ldots \ldots \ldots . \ldots 7$

REFERENCES ........................................ 64

Appendix A: SUMMARY OF ENERGY DEMAND AND FUEL MIX $\ldots \ldots \ldots \ldots \ldots \ldots \ldots . \ldots 68$

Appendix B: FUEL MIX TABLES $\ldots \ldots \ldots \ldots \ldots \ldots \ldots \ldots \ldots \ldots \ldots \ldots \ldots \ldots \ldots$ 
S-1 TVA Modal Transportation Projections $\ldots \ldots \ldots \ldots \ldots \ldots \ldots \ldots \ldots$

S-2 Energy Intensiveness by Transport Mode $\ldots \ldots \ldots \ldots \ldots \ldots \ldots \ldots$

II-1 Residential Building Types in the TVA Region $\ldots \ldots \ldots \ldots \ldots \ldots \ldots \ldots$

II-2 TVA Population and Households, $1975-2000 \ldots \ldots \ldots \ldots \ldots \ldots \ldots \ldots$

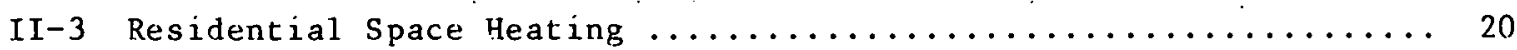

II-4 Residential Appliances.-- Energy Use and Regional Market . 35

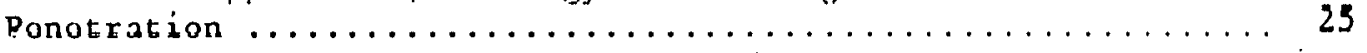

II-5 Commercial Inventory in the TVA Region $-1975 \ldots \ldots \ldots \ldots \ldots \ldots \ldots 28$

II-6 Unit Energy Demand in Commercial Buildings, TVA - $1975 \ldots \ldots \ldots . \ldots 31$

II-7 Functional Use of Energy in the U. S. for Agricultural

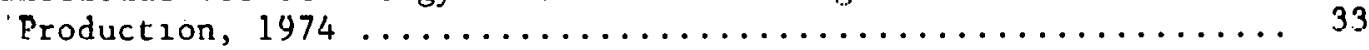

II-8 Fuels and Electricity Used in Agricultural Production, $1974 \ldots \ldots 33$

II-9. Regional Variations in Energy Per Value Added and the Price. of Electricity ............................. 40

II-10 Industrial Energy Consumption vs GNP in the United States......40

II-11 Automobile Fuel Economy $-1985 \ldots \ldots \ldots \ldots \ldots \ldots \ldots \ldots \ldots \ldots \ldots$

II-12 TVA Modal Transportation Projections $\ldots \ldots \ldots \ldots \ldots \ldots \ldots \ldots \ldots$

II-13 Energy Intensiveness by $\operatorname{Transport~Mode~} \ldots \ldots \ldots \ldots \ldots \ldots \ldots \ldots$

III-1 TVA Electric Generation - By Central Station Power Plant ...... 52

III-2 Generating Capacity on June $30,1976 \ldots \ldots \ldots \ldots \ldots \ldots \ldots \ldots$

IV $=1$ Impaci of Indusleial oil Cunservaliun, $1905 \ldots \ldots \ldots \ldots \ldots \ldots \ldots \ldots$

A-1 Sumnary of Energy Demand and Fuel Mix, $1975 \ldots \ldots \ldots \ldots \ldots$

A-2 Summary of Energy Demand and Fuel Mix, $1980 \ldots \ldots \ldots \ldots \ldots \ldots \ldots$

A-3 Summary of Energy Demand and Fuel Mix, $1985 \ldots \ldots \ldots \ldots \ldots \ldots \ldots$

A-4 Summary of Energy Demand and Fuel Mix, $2000 \ldots \ldots \ldots \ldots \ldots \ldots \ldots$ 
TABLES (Continued)

FUEL MIX TABLES - APPENDIX B

Page

Residential Space Heating - Projected Fuel Mix ............ 75

Residential Water Heating - Projected Fuel Mix $\ldots \ldots \ldots \ldots \ldots \ldots 77$

Residential Air Conditioning - Projected Fuel Mix ........... 78

Residential Cooking - Projected Fuel Mix ................ 79

Residential Appliances and Lighting - Projected Fuel Mix ....... 80

Commercial space Heating - Projected Fuel Mix ............. 81

Commercial Water Heating - Projected Fuel Mix ............. 82

Commercial Cooking - Projected Fuel Mix ............... 83

Commercial Air Conditioning - Projected Fuel Mix ............ 84

Commercial Lighting, Appliances and Refrigeration - . . . $\quad 8 . \ldots 5$

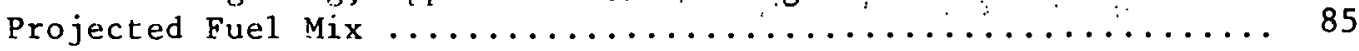

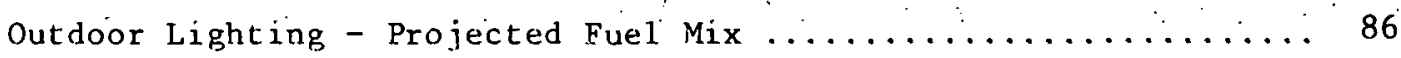

Agriculture - Projected Fuel Mix ................. 87

Mining - Projected Fuel Mix $\ldots \ldots \ldots \ldots \ldots \ldots \ldots \ldots \ldots \ldots$

Al uminum - Projected Fuel Mix $\ldots \ldots \ldots \ldots \ldots \ldots \ldots \ldots \ldots \ldots \ldots$

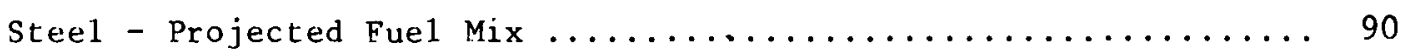

Industrial Process Heat - Projected Fuel Mix ............. 91

Industrial Electric Drive - Projected Fuel Mix ............. 92

Petrochemicals - Projected Fuel Mix ................... 93

Uranium Enrichment - Projected Fuel Mix ................. 94

Automobile - Projected Fuel Mix $\ldots \ldots \ldots \ldots \ldots \ldots \ldots \ldots \ldots \ldots \ldots$

Truck and Bus - Projected Fue1. Mix ................... 96

Railroads - Projected Fuel Mix ..................... 97

Air Transport - Projected Fuel Mix ................. 98

Water Transport - Projected Fuel Mix .................. 99

Electric Utility - Projected Fuel Mix .................. 100 
S-1 Primary Energy - TVA Region $\ldots \ldots \ldots \ldots \ldots \ldots \ldots \ldots \ldots \ldots \ldots \ldots \ldots$

S-2 Delivered Energy to the TVA Region $\ldots \ldots \ldots \ldots \ldots \ldots \ldots \ldots \ldots$

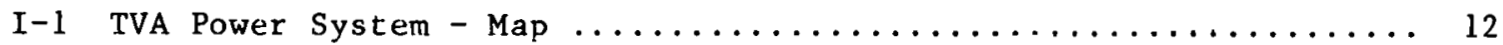

II-1 Annual Air-Conditioner Compressor-Operating Hours for Homes

That are Also Naturally Ventillated .................. 23

II-2 Annual Air-Conditioner Compressor-Operating Hours for Homes That ait Not Naturally Ventillated .................. 23

11-1 Induotrial Enetgy Consumption Relative to GNP, $1951-2000 \ldots \ldots \ldots 41$

III-1 Projected Electric Generation in the TVA Region ............ 54

IV-1 TVA Reference Energy System, Year $1975 \ldots \ldots \ldots \ldots \ldots \ldots \ldots \ldots \ldots \ldots \ldots \ldots \ldots$

IV-2 TVA Reference Energy System, Year $1980 \ldots \ldots \ldots \ldots \ldots \ldots \ldots \ldots \ldots$

IV-3 TVA Reference Energy System, Year $1985 \ldots \ldots \ldots \ldots \ldots \ldots \ldots \ldots \ldots$

IV-4 TVA Reference Energy System, Year $2000 \ldots \ldots \ldots \ldots \ldots \ldots \ldots \ldots$ 
SUMMARY

Recent world events have led this nation to reexamine its energy priorities in. terms of the production and demand for energy. Alternative conservation strategies, environmental policies and new supply technologies are several of the issues receiving increased attention as the United States attempts to develop a sound national energy policy. To assess the impact of alternative sources of energy, technologies and policies on the nation's energy system requires an analytical framework which incorporates the entire energy system. The systems formulation presented in this report is based on the Reference Energy Systems approach and incorporates all resources, technologies and uses of energy in a uniform manner. The Reference Energy System has traditionally been applied to the assessment of energy technologies and policies on a national level. This report presents a reformulation of the projection methodology developed on a national level and applies it to an electric utility region--The Tennessee Valley Authority. Reference Energy Systems have been developed for the region serviced by TVA for the base year 1975 and projections developed for the years 1980,1985 and 2000 .

Brookhaven National Laboratory and the Tennessee Valley Authority have entered into a cooperative agreement to model the energy system for the area serviced by TVA. This cooperative arrangement has proven mutually. beneficial to both TVA and Brookhaven. TVA has agreed to supply the energy and economic data that are available to them for the region. Brookhaven has responsibility in the project for developing the energy model and deriving regional estimates of energy supply and demand not provided by TVA. A unique advantage of using the system presented here for utility planning is its overall view of the entire energy system as opposed to an analysis limited exclusively to the electric sector.

Final demands are disaggregated into twenty-five end-use demand caregorles withlin the residential, commercial, industrial and transportation sectors. Demand for energy in the residential sector is disaggregated into space heating, water heating, cooking, air conditioning, appliances and lighting. Space heating in the TVA region consumed $59 \%$ of the energy required by the residential sector in 1975 . This figure is computed from the energy demand per household, $42 \times 10^{6} \mathrm{Btu}$ 's/household; the number of households, $2025 \times 10^{3}$ households; and the market penetration for space heating in the TVA 
region, 100\%. The basic energy demand for space heating, appearing in the Reference Energy System under the column heading DEMAND CATEGORY, is computed as the product of the delivered energy' and the end-use device efficiency. The basic energy demand represents the net energy required to deliver a given level of service, for example, to maintain room temperature at $72^{\circ} \mathrm{F}$. The proportion of households in the region using electricity to meet their space heating requirements is projected to increase from $43 \%$ in 1975 to $62 \%$ in 2000 . The low cost of electricity and the relatively moderate climate in the region explain the continued reliance on electxicity for space heating. Enexgy requirements for residential water heating, cooking, air conditioning, appliances and lighting are computed using a methodology analogous to that used for residential spare heating:

The commercial sector incorporates a wide range of activities which can be disaggregated into two broad categories: 1) buildings and 2) agriculture and mining. A methodology analogous to the one followed in the residential sector is used to estimate the energy consumed in commercial buildings for space.conditioning, water heating, cooking, lighting, refrigeration, computers and other electxical appliances. The commercial inventory in the TVA region was 680 million square feet in 1975 and is projected to 1980,1985 and 2000 in proportion to output in the services sector for the U.S. from the Brookhaven National Laboratory input-output model, adjusted by regional earnings as follows:

TVA COMMERCIAL INVENTORY ${ }_{t}=$

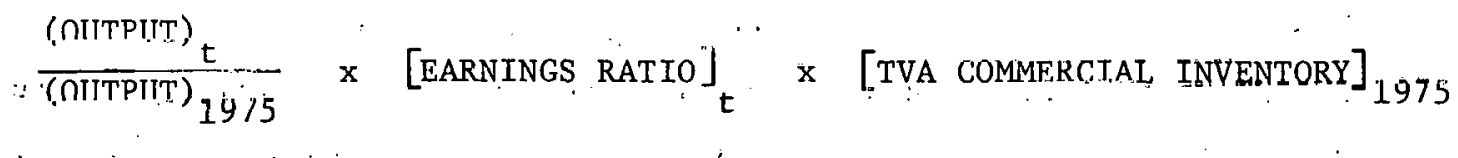
$\because$.

where, OUTPUT $=$ Dollars of output in the services sector from the $I / 0$ model for the U.S. $t^{-} \cdot$ : = Projection year -- 1980, 1985, 2000 .

The regional adjustment or "Earnings Ratio" is computed as the ratio: of projected regional earnings in the commercial sector tn projerted U.S. carningo in the com mercial sector: normalized to 1970 as follnws:

$$
\therefore \quad \text { [EARNINGS RATIO }_{t}=\left[\left(\frac{\mathrm{E}_{\mathrm{TVA}}}{\mathrm{E}_{\mathrm{U} . \mathrm{S} .}}\right)_{\mathrm{t}} /\left(\frac{\mathrm{E}_{\mathrm{TVA}}}{\mathrm{E}_{\mathrm{U} . \mathrm{S} .}}\right)_{1970}\right]
$$

where, $\mathrm{E} \quad=$ Earnings in the commercial sector

$t \quad=$ Projection year -- 1980, 1985, 2000 . 
arnings in the TVA region are derived from earnings in each of the states assuming earnings are proportional to population.

Agricultural uses of energy associated with on-the-farm operations to grow crops and raise livestock are currently estimated to be 2014 trillion Btu's in the U.S. This includes such indirect uses of energy as the production of fertilizers and pesticides. Energy associated with agricultural production is regionalized from national totals for 1975 by assuming energy demand in the TVA area is proportional to farm acreage. Mineral industries in the TVA region are primarily engaged in the mining of bituminous coal and lignite, the nonferrous metal ores bauxite and zinc, and the mining and quaxrying of the nonmetallic minerals stone, clay and phosphate rock. Consumption of energy in. the TVA region is derived from value added for these mineral industries. The basic . energy demand derived for both agriculture and mining is escalated to 1980,1985 and 2000 in proportion to projected output in the agricultural and mining sectors, respectively, of the BNL input-output model for the U.S. adjusted by regional earnings.

The industrial sector has been disaggregated into several major energy-intensive industries including aluminum, steel, petrochemicals and uranium enrichment; remaining industrial energy requirements (excluding petroleum refining) are included in the demand categories industrial process heat and industrial electric dxive. Energy requirements for industrial process heat are initially estimated by determining overall industrial energy requirements. Industrial process heat then represents the balance of unaccounted fuels in the industrial sector after all other end uses are accounted for. It is assumed that overall energy requirements in the industrial sector in 1975 are proportional to regional value added in manufacturing. Regional value added is estimated in proportion to population. Energy. requirements for industrial process heat, escalated at an annual growth rate of $3.6 \%$ from 1975 to 2000 , are derived from the historical ratio of U.S. energy consumption in the industrial sector to gross national product (GNP) adjusted by regional earnings. The ratio uf Industrial energy consumption to GNP has been declining over time at the rate of 241 Btu pex dollar of GNP pex year. If it is assumed that this energy/GNP ratio continues to decline as it has since 1960, and that GNP increases at an annual rate of $3.2 \%$ between 1975 and 2000, then the demand for energy by industry in the U. S. will increase at an annual rate of $2.6 \%$ ovex the reference years compared to $3.6 \%$ in the TVA region. This regional variation in the demand for energy reflects the increasing proportion of earnings projected to originate in the region over the next 25 years.

In 1975 the automobile consumed 52\% of the energy in the transportation sector compared to $31 \%$ projected for 2000 , reflecting improved automobile fuel economy and 
market saturation. Automobile gasoline consumption is computed as a function of the number of registered vehicles, miles traveled per vehicle $(10,800)$, and the fleet average fuel economy. The number of registered vehicles, expected to be an increasing proportion of the driving age population, is projected to increase from .61 vehicles per driving age population in 1975 to .85 vehicles per driving age population in 2000. The fleet average fuel economy is computed as a function of the mix of model years on the road, the distribution of vehicle-miles with the age of the vehicle, and the fuel efficiency per model year. The fuel efficlency per model year is assumed to be $10 \%$ lower than specified in the Energy Policy and Conservation Act because of nonoptimum engine performance in older model vehicles. The fleet average fuel economy projected for 1980,1985 and $200 n$ is $18.9 \mathrm{mpg}, 19.3$ mpg and $2 b \mathrm{mpg}$, respectively.

The truck and bus demand category includes all gasoline and diesel fuel not consumed by automobiles, excluding marine and aviation uses of motor fuels. Trucking activity is subdivided into two classes: 1) freight trucking (measured in terms of ton-miles) includes all trucks over $10,000 \mathrm{lbs}$ GVW and 2) nonfreight trucking (measured in terms of truck-miles) includes all trucks under 10,000 lbs GVW. Historically, freight trucking activity in tle U.S. hac inrreased in proportion to GNP, and this trend is projected to continue through the year 2000. Regional freight trucking activity is derived from U.S. projections based on regional earnings and is projected to increase from 16 bill1on ton-miles in 1975 to 45 billion ton-miles in 2000 at an annual rate of $4.2 \%$. The consumption of jet fuel by commercial air carriers, diesel fuel by railroads, and fuel oil by commercial shipping is projerted in proportion to the modal transportation projections ehown in Tables $s-1$ and $s-2$.

Coal production in the TVA region was appruximately 27 million tons in 1975 and was estimated from data fox individual. counties within the region. Coal production is projected to increase at the same rate as forecast for the Interior Appalachia region from the "Recent Trends" scenario in the National Coal Assessment. This results in growth edtes of 3.5\% from 1975 to 1985 and $1.8 \%$ thereaflex. The Tennessee Valley Authority has traditionally depended upon hydroelectric powex and coal to meet its powex requixements. Electricity generated from nuclear plants is playing an increasing role in meeting the system's demand for base load electric power with gas turbines and pumped storage being used to meet the system's demand for peak power. Electricity generated from coal steam-plants met $72 \%$ of the demand for electric power in 1975, hydroelectric power satisfied $20 \%$ of demand, and 
electricity generated from nuclear plants and gas turbine peaking units accounted for the remainder of the load in 1975. Electricity sales totaled 381 trillion Btu's or 112 billion kilowatt-hours in 1975, remaining approximately constant since 1973 . Recent electric utility forecasts of future energy requirements have been reduced from what they were in the 1972 to 1973 time period. Higher energy prices, depressed economic conditions, and the "conservation ethic" have all been contributing factors to the low energy growth recently experienced. These factors have all added a considerable degree of uncertainty to future projections. Traditionally, utilities have depended upon historical trends in forecasting future loads, but this method is rapidly being replaced by more sophisticated techniques using econometrics and detailed engineering analyses of demands. A systems approach using the latter technique is being applied in this study to project requirements for fuel and electric power.

The mix of capacity additions projected for the Tennessee Valley Authority in 2000 results in a generation mix of $35 \%$ coal-steam and $57 \%$ nuclear steam with the remainder of the load being met by hydro, pumped storage and gas turbine peaking units. No capacity additions to hydropower are planned after 1980 and the electricity generated from hydro is projected to decrease from 22950 million kilowatthours in 1975 to 18276 million in 1980 and then remain constant at that level through the year 2000. Pumped storage is projected to play an increasing role in meeting the system's demand for peak power with four units totaling 1530Mw expected to be operational within the year and $5430 \mathrm{Mw}$ projected to be on line by the year 2000. No additional gas turbine peaking units are planned after 1980. Coal continues to be an important fuel in meeting TVA's energy requirements, although nuclear power dominates the schedule of planned additions over the next twenty-five years.

The overall demand for primary energy in the TVA region is projected to increase at an annual rate of $3.5 \%$ between 1975 and 2000 compared to a national growth rate of approximately $2.5 \%$ (see Figure $\mathrm{S}-1$ ). This regional variation in the demand for energy reflects the increasing proportion of earnings projected to originate in the region by the year 2000. Total earnings is projected to increase at an annual rate of $3.7 \%$ in the U.S. compared to $4.1 \%$ in the TVA region. The demand for delivered energy in the TVA region is projected to increase at an annual rate of about $2.5 \%$ for gas and oil and $4.9 \%$ for coal as shown in Figure $\mathrm{s}-2$. The relatively high growth in coal consumption is due to the increased use of coal by industry. The demand for electricity in the TVA region is projected to increase at an annual rate गf $4.1 \%$ between 1975 and 2000 compared to a $4.6 \%$ growth rate in the preceding decade. 
Table S-1

TVA MODAL TRANSPORTATION PROJECTIONS

(Billions)

\begin{tabular}{|c|c|c|c|c|}
\hline & 1975 & 1980 & 1985 & 2000 \\
\hline \multicolumn{5}{|l|}{ Passenger-Miles } \\
\hline Air & 2.2 & 3.4 & 4.7 & 10.7 \\
\hline Local \& Intercity Bus & 1.4 & 1.9 & 2.2 & 3.9 \\
\hline School Bus & 1.2 & 1.3 & 1.3 & 1.4 \\
\hline \multicolumn{5}{|l|}{ Ton-Miles } \\
\hline Air & - & - & - & - \\
\hline 10,000 lbs.) & 16 & 20 & 25 & 45 \\
\hline Ship & 75 & 14 & 13 & 47 \\
\hline Rail & 26 & 30 & 34 & 48 \\
\hline \multicolumn{5}{|l|}{ Truck-Miles } \\
\hline Non-freight Trucking & 9 & 12 & 16 & 31 \\
\hline
\end{tabular}

Table S-2

ENERGY INTENSIVENESS BY TRANSPORT MODE

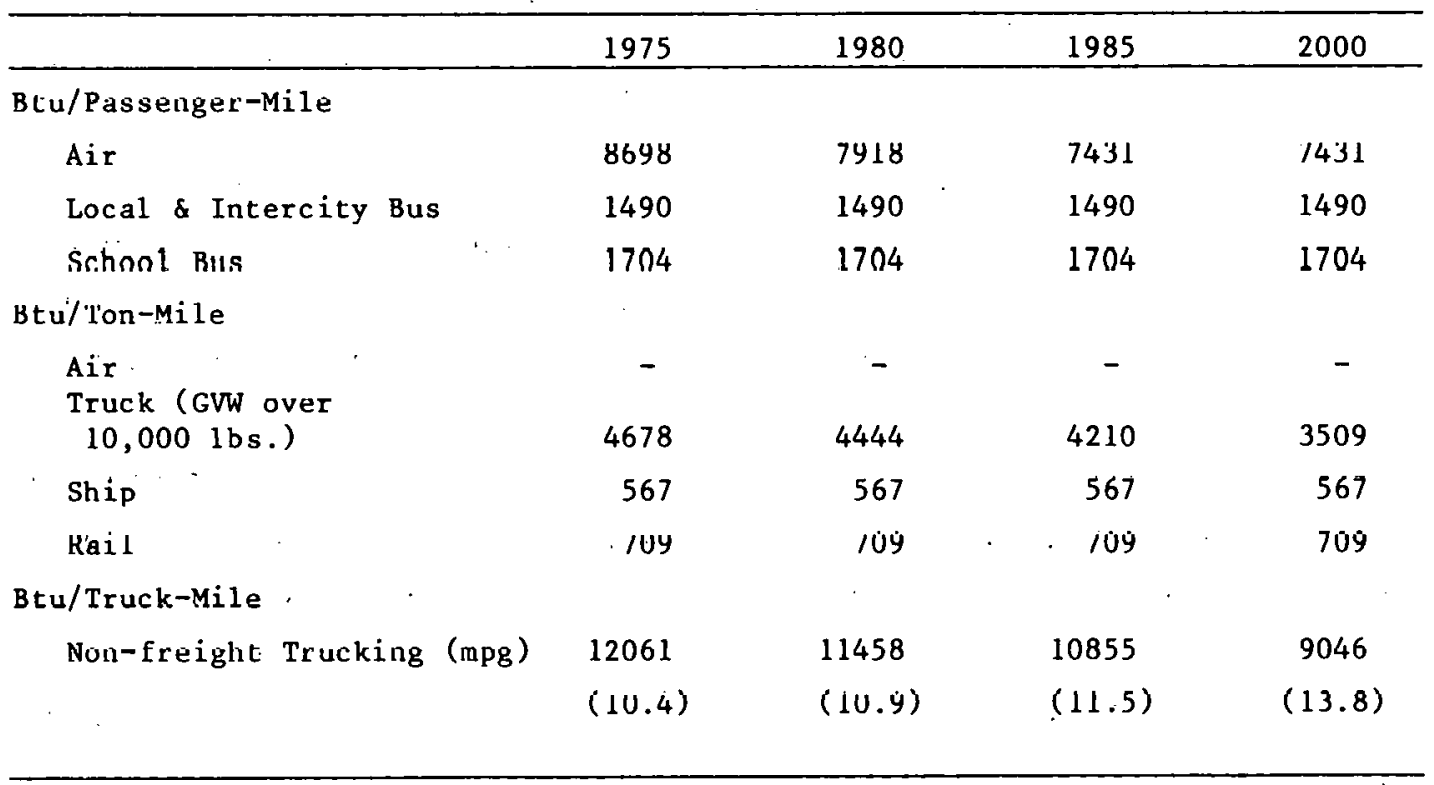




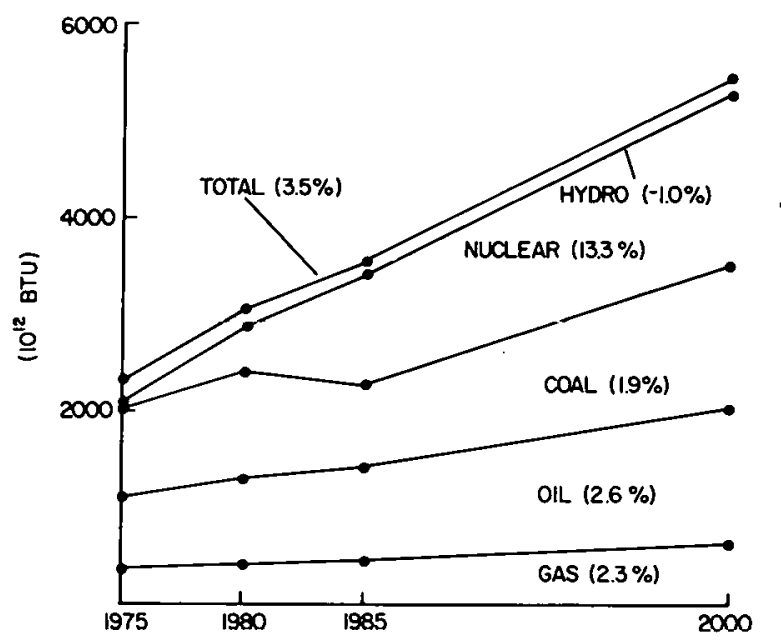

PRIMARY ENERGY - TVA REGION

Figure S-1. Primary energy - TVA region.

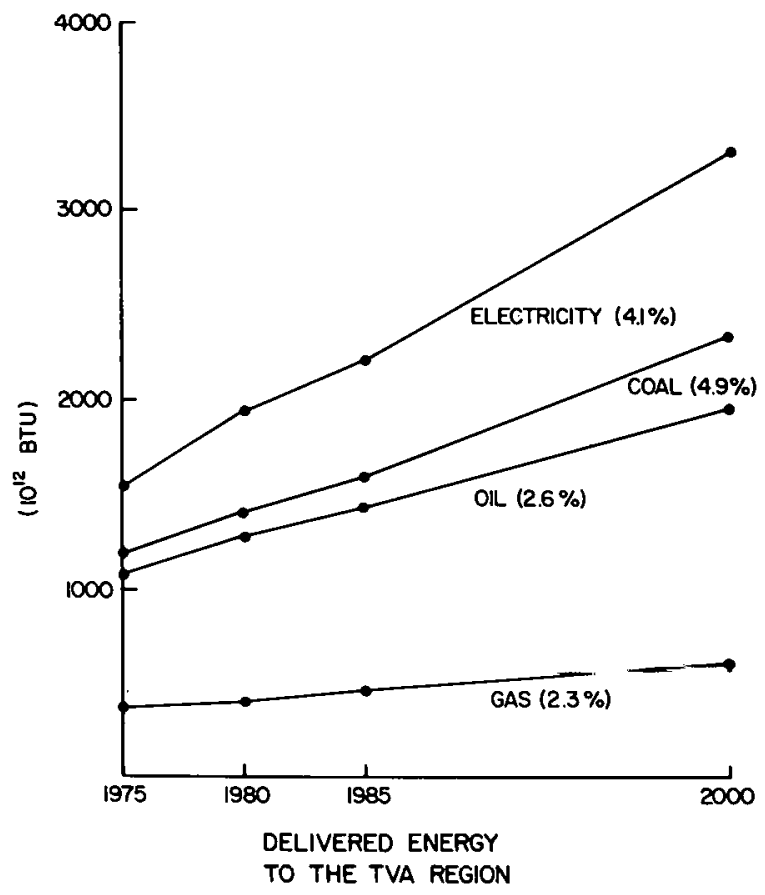

Figure S-2. Delivered energy to the TVA region. 


\section{THIS PAGE}

\section{WAS INTENTIONALLY}

LEFT BLANK 


\section{INTRODUCTION}

The United States has traditionally been an energy independent country relying upon its own plentiful supply of resources to meet its energy needs. Over the past decade this situation has reversed itself as the nation has increasingly relied on imported oil. In 1970 the U.S. imported 3.4 million barrels of oil per day to meet about $25 \%$ of its demand for petroleum products. Since 1970 oil imports have more than doubled reaching 8.7 million barrels of oil per day in 1977 to meet nearly 50\% of the nation's demand for petroleum. This rising level of imported energy coupled with the dramatic price increases following the Arab oil embargo of 1973 have led to a reexamination of the nation's energy priorities in terms of the production and demand for energy. Alternative energy sources such as coal synthetics, solar, and nuclear power have been receiving increased attention. Conservation strategies such as improvements in end-use device efficiency and in building construction practices, as well as specific lifestyle changes, are being pursued as a result of both government regulation and price inducement. To assess the impact of these alternative sources of energy, technologies, and policies on the nation's energy system requires an analytical framework which incorporates the entire energy system. The systems formulation presented in this report is based on the Reference Energy System approach and incorporates all resources, technologies and uses of energy in a uniform manner.

The Reference Energy System is a network representation of the technical activities required to supply various forms of energy to end-use activities and has wide application in the assessment of energy technologies and policies. Technolo-": gies are defined for all operations involving specific fuels including resource : " $: 3$ extraction, refinement, conversion, transportation, distribution, and utilization: $\cdots$ Each of these activities is represented by a link in the network for which an efficiency is specified. The network is quantified for a given year with the level of energy demands and the energy flows through the supply activities that are required to serve these demands. 
The Reference Energy System has traditionally been applied to the assessment of energy technologies and policies on a national level. The diversity of energy consumption across the United States is such that regional analysis of energy resources and consumption is essential for any meaningful analysis of policy issues. Both energy resources and end uses have such widely varying characteristics on a national level that analyses of such issues as conservation strategy, utility load forecasting, new technology implementation, and environmental policy require an indepth knowledge of energy requirements on a regional level.

This report presents a reformulation of the projection methodology developed on a national level and applies it. to an electric utility region--the Tennessee Valley Authority. Reference Energy Systems have been developed for the region serviced by. TVA for the base year 1975 and projections were developed for the years 1980, 1985 and 2000. Brookhaven and the Tennessee Valley Authority have entered into a cooperative agreement to model the enexgy system for the area serviced by TVA. This region, typical of the area serviced by many utilities, cuts across both sțate and county political boundaries. Thus energy supply and demand data available for political entities from published government statistics can not be utiliz... ed directly in this study. The Tennessee Valley Authority has agreed to supply Brookhaven with the necessary energy and economic data available to them for the region. Brookhaven has responsibility in the project for developing the energy model and deriving regional estimates of energy supply and demand not provided by TVA. This cooperative arrangement has proven mutually beneficial to both TVA and Brookhaven. As a result of this study the Tennessee Valley Authority currently has access to energy consumption data for all fuels consumed in the regloh. These data were not available previously. In addition, TVA is planning to run the Brookhavon Energy System Optimization Model using the Reference Energy Systems developed in this study as input. Brookhaven has had an opportunity to successfully demonstrate the applicability of its modeling capabilities to a utility region. The general methodology demonstrated in this study is also directly transferrable to other utility. regions. The methodology employed in dexiving regional energy demands in the residential, commercial, industrial and txansportation oectors is rescribed in Section II. The methodology employed in developing the enexgy supplicu fur the region including the electric utility sector is discussed in Section III.

The Tennessee Valley Authority is a wholly owned corporate agency of the United States government established by Act of Congress in 1933 to develop the Tennessee River System and to assist in the development of other resources in the Tennessee Valley. The production and sale of electric power are part of TVA's resources 
program. TVA supplies power at wholesale to 160 muniripal and cooperative distributors which in turn distribute power to about 2.5 million residential, commexcial and industrial customers. These customers are located in seven states including the entire state of Tennessee and parts of Alabama, Georgia, Kentucky, Mississippi, North Carolina and Virginia as shown on the map of the TVA Power System (Figure I-1). TVA also serves directly 49 industrial customers with large or unusual power requirements and several federal installations including uranium enrichment plants located at Oak Ridge, Tennessee and Paducah, Kentucky.

The Tennessee Valley Authority has traditionally depended upon hydroelectric power and coal to meet its power requirements. Electricity generated from nuclear plants is playing an increasing role in meeting the system's demand for base load electric power with gas tuxbines and pumped storage being used to meet the system's demand for peak power. Electricity generated from coal-steam plants met $72 \%$ of the demand for electric power in 1975. This is projected to decrease to $35 \%$ by 2000 as the nuclear plants presently under construction become operational. By the year 2000 nuclear generating capacity is projected to reach approximately 30,000Mw, meeting over $50 \%$ of the systems demand for electricity. No substantial additions to hydroelectric generating capacity are planned over the next twenty-five years.

A unique advantage of using the system presented here for utility planning is its overall view of the entire energy system as opposed to an analysis limited exclusively to the electric sector. This systems approach allows a utility to assess the impact of alternative technologies and policies across the entire energy system. Recent electric utility forecasts of future energy requirements have been reduced from those made in the 1972 to 1973 time period. Higher energy prices, depressed economic conditions and conservation have all been contributing factors to the low energy growth recently experienced. These factors have added a considerable degree of uncertainty to future projections. Traditionally, utilities have depended upon historical trends in forecasting future loads, but this method is rapidly being replaced by more sophisticated techniques using econometrics and detailed engineering analyses of demands. A systems approach using the latter technique is being applied in this study to project requirements for fuel and electric power. Demand patterns for twenty-five end-use demand categories within the residential, cummercial, industrial and transportation sectors are developed for a base case scenario representing reasonablc energy use patterns derived in a consistent mannex by applying engineering techniques to the best available information. Demand for electric power is then obtained from the summation of electric demands over all other demand categories. 


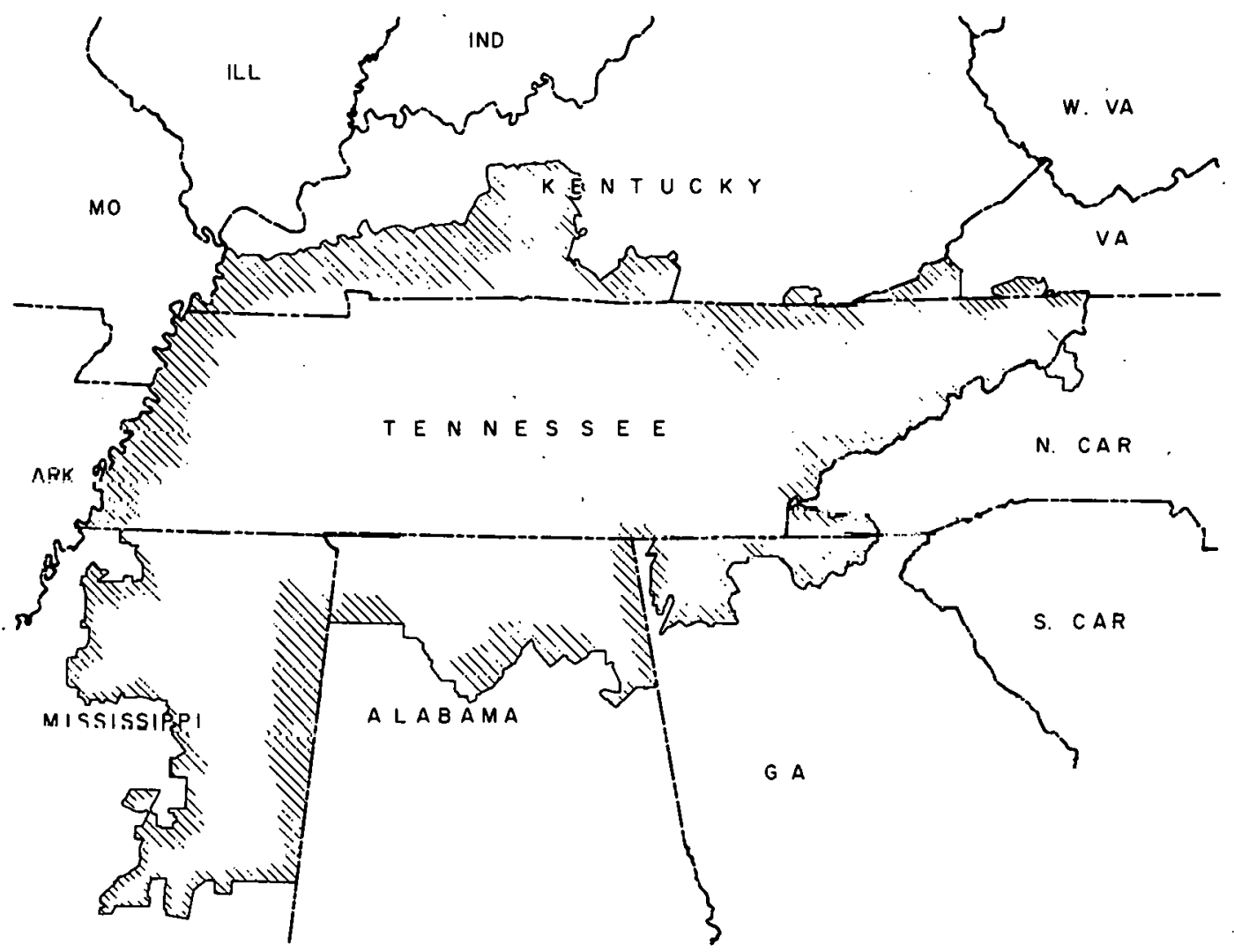

Figure I-1. TVA puwer syatcm - map, 
The Reference Energy Systems presented here were formulated with minimal introduction of new technologies, and projections were dexived from data available in the various sectors. Allowances for tnoderate conservation were incorporated into the energy systems in appropriate demand categories where the technology currently exists. These reductions in energy demand brought about by government regulation or price-induced cutbacks in consunption include a $15 \%$ efficiency improvement for air transportation, a $25 \%$ efficiency improvement for trucks, and a fleet average fuel economy of 25 miles pex gallon for automobiles by the year 2000 . In the residential sector new construction practices and retrofitting in older homes over the next twenty-five years are assumed to reduce the heat loss of a typical household by $10 \%$. Reductions in industrial energy requirements per dollar of GNP observed since 1960 are assumed to continue, reducing the growth rate of energy consumed by industry in the TVA region from $4.2 \%$ to $3.6 \%$ over the reference years. Detailed assumptions regarding those conservation measures explicitly included in the projections are noted in the Fuel Mix Tables in Appendix $B$.

Fundamental to the proper use of information contained in this report is recognition that data presented here are base line projections and must not be construed as predictions of the future. These projections are not forecasts of what "will be", but are intended to be used for technology assessments (see Section IV). They are reference projections in the sense that new technologies are not included in the projections. This does not imply that new technologies such as the electric car will not be prevalent by the year 2000, but it allows these new technologies to entex the system in some predetexmined fashion. The impact of a new technology in terms of resource consumption may be evaluated by modifying the energy flow paths to incorporate the new technology. Alternate paths through the network reflect the substitutability of resources and technologies for one another. 


\section{THIS PAGE}

\section{WAS INTENTIONALLY \\ LEFT BLANK}


The methodology for developing final energy demands and the fuel mix in each demand sector is discussed in this section. Final demands are disaggregated into the following end-use categories:

RESIDENTIAL

Space Heating

Water Heating

Air Conditioning

Cooking

Appliance and Lighting

INDUSTRIAL

Aluminum

Steel

Petrochemicals

Process Heat

Electric Drive

Uranium Enrichment
COMMERC IAL

Space Heating

Water Heating

Air Conditioning

Cooking

Applicance and Lighting

Outdoor Lighting

TRANS PORTATION

Autounobiles

Truck and Bus

Railroads

Air

Ship

Pipelines

AGRICULTURE

MINING

ELECTRIC UTILITIES

These final demands drive the Reference Energy System, that is, the "intermediate energy form" appearing in the RES between the column headings DECENTRALIZED CONVERSION aud UILIZING UEVICE is initially computed for each of the above end-use categories. Intermediate energy forms include txanswitted and distributed electricity, for example, gasoline in an automobile, or oil in a home oil tank. Intermediate energy or delivered energy is generally computed as a function of demand per unit (i.e., per household or per ton of steel), basis for energy requirements (i.e., number of households or tons of steel), and the level of market penetration. In the case of residential space heating: 


$$
\begin{aligned}
& \text { SPACE HEATING DEMAND }=\text { UNIT DEMAND } \mathrm{X} \text { BASIS } \mathrm{X} \text { SATURATION } \\
& \text { [Btu's] }=\left[\frac{\text { Btu's }}{\text { Household }}\right] \times\left[\begin{array}{c}
\text { of house- } \\
\text { holds }
\end{array}\right] \times \quad[1.00]
\end{aligned}
$$

The values on the right hand side of the RES under the heading DEMAND CATEGORY represent the basic energy demand for the above set of end-use categories. These basic energy demands should be distinguished from the more commonly used fuel demands (intermediate energy forms) indicated above. Basic energy demand represents the net energy required to provide a given level of service, e.g., to maintain room temperature at $72^{\circ} \mathrm{F}$. It is derived from the various fuel requirements and the fuel efficiencies of utilizing devices. This is useful both conceptually, since it more closely represents the level of service rendered by energy use, and for projection purposes since $1 t$ is directly related to underlying causalive factors, e.g., number of households, vehicle-miles, etc.

"Fuel Mix Tables" are included in Appendix B for each end-use category containing a detailed description of 1) reference technologies ut1lized, 2) derivation of fuel demands and efficiencies for the year 1975 and 3) the basis of energy projections. Data sources referenced in deriving the base case and projected energy demands are noted in the Fuel Mix Tables. Values for fuel fraction $\left(f_{j}\right)$, fuel demand $\left(D_{i}\right)$, relative effectiveness $\left(e_{i}\right)$, saturation $(S)$, and basis of projection (B) for each demand category are included in the Fuel Mix Tables with definitions of the above terminology preceding the tables. The Basic Energy Demand (E) is computed in the Fuel Mix Tables as the intermediate energy form (as listed in Tables A-1 through A-4 of Appendix A) times the relative efficlency ( $e_{i}$ ) summed over all fuele:

$$
E=\sum_{i} D_{i} \times e_{i}
$$

This is a measure of the energy requireinent and is independent of the fuel or energy form employed. The Unit Baslc Energy Demand $\left(E_{\mathrm{u}}\right)$ is the Basic Energy Demand per unit (e.g., per household).

The projected Basic Energy Demand as defined above accounts for 1) any saturation effects that may be present (i.e., 100\% of the households are alr conditloned by 2000), 2) the effect of overall growth in households, vehicle-miles, tons of steel, etc., and 3) changes in the Unit Basic Energy Demand due to technological or conservation efforts. The fuel $\mathrm{mix}$ is then specified in terus of fuel fraction 
$\left(f_{i}\right)$ for each reference year allowing for switches to alternative fuels. For example, a shift from natural gas to electricity in residential cooking is forecast.

The relative efficiencies $\left(e_{i}\right)$ of the various fuels that satisfy the projected basic energy demands are specified in the Fuel Mix Tables. It is more accurate to consider these efficiencies in terms of relative effectiveness since this both reflects the technical efficiency of an end-use device, and takes differences in utilization practices between fuels into account. Thus, the "efficiency" that is derived from 1975 data for commercial space heating supplied by electric resistance heat ${ }^{l}$ has a value of 1.00 compared with 0.4 for gas; this reflects the improved insulation that is generally used with electric heat as well as the higher technical efficiency. The relative effectiveness is also employed to reflect differences between reference years. Existing construction practices are gradually improving the insulation levels of the overall fossil-heated housing stock; this is taken into account by increasing the efficiency factor, $e_{i}$.

The remainder of this section describes the underlying methodology in the development of each demand sector in the base case and projected RES's.

RESIDENTIAL SECTOR

Demand for energy in the residential sector is computed as follows:

$$
\text { (Fuel Demand) }{ }_{i}=\sum_{i}\left(D_{i j} \times B_{j}\right) \times S_{i}
$$

where $D_{i j}=$ Annual fuel demand for end use $i$ and housing type $j$.

$B_{j} \quad=$ Number of households per housing type $j$.

$s_{i} \quad=$ Market penetration of end-use $i$.

$i \quad=$ End-use $1, \ldots$, end-use $i$, end-use $i+1, \ldots$

$\mathrm{j} \quad=$ Housing type $1, \ldots$, housing type 5 (for space heating)

$j \quad=1$ (for other end-uses).

'the housing stock is divided into five distinct housing types according to the Census of Housing:

- Mobile Homes

- Single-family Detached

- Single-family Attached

- Multi-family Low Rise

- Multi-family High Risc

${ }^{1}$ The value appearing in the commercial space heating Fuel Mix Table has a value of 1.018 because it is weighted by the C.O.P. for heat pumps. 
Residential building types for 1975 were estimated using 1970 Census of Housing(2) data and data provided by TVA for 1975. Projected changes in the housing mix are assumed to follow those forecast for the East South Central Census Region. (30) The greatest change occurs in the number of mobile homes,

Table II-1

RESIDENTIAL BUILDING TYPES IN THE TVA REGION

(Thousands)

\begin{tabular}{lrrrr}
\hline Building Type & 1975 & 1980 & 1985 & 2000 \\
\hline Mobile Homes & 87 & 171 & 207 & 263 \\
Single-Family Detached & 1632 & 1735 & 1921 & 2361 \\
Single-Family Attached & 184 & 219 & 254 & 331 \\
Mult1-Fam1ly Low Rlse & 83 & 89 & 107 & 138 \\
Multi-Family High Rise & 39 & 47 & 57 & 75
\end{tabular}

projected to increase by a factor of three over the next twenty-five years. Also, the percentage of single-family detached households in the region decreases from $81 \%$ to $75 \%$ as the number of multi-family housing units increase. This can be attributed to a combination of factors including a predicted decrease in the ratio of persons per household and the escalating cost of owning your own home.

The population in the TVA service area in 1975, 1980, 1985 and 2000 is derived from population estimates reported by TVA for the years 1972 through 1990. The population is projected to increase between 1990 and 2000 at the same rate as it did from 1985 to 1990 (see Table II-2). The number of households in the TVA service area in 1975, 1980, 1985 and 2000 is dexived from household estimates reported hy TVA for the years 1972 through 1990. The number of households is projected to increase between 1990 and 2000 such that the population per household ratio decreases at a decreasing rate, leveling off at 2.50 in 2000 .

Table II-2

TVA POPULATION AND HOUSEHOLDS, 1975 - 2000 (Thousands)

\begin{tabular}{lllll}
\hline & 1975 & 1980 & 1985 & .0000 \\
\hline Population & 6290 & 6630 & 6940 & 7919 \\
Number of Households & 2025 & 2261 & 2546 & 3168 \\
Population/Household & 3.11 & 2.93 & 2.73 & 2.50 \\
\hline
\end{tabular}


In addition to projecting total population in the TVA service region, it was also necessary to estimate regional population at a state and county level for the year 1975. State and county population data are used in deriving energy consumption in the commercial, industrial and transportation sectors as will be described in this section. The population in each state that is serviced by TVA is equal to the sum of the Individual county populations within that state serviced by TVA. $\operatorname{POP}_{\text {STATE }_{j}}^{\text {TVA }}=\sum_{i}^{\text {COUNTY }}\left(\right.$ POP $_{\text {county }_{i}}^{\text {TVA }}$ state $\left._{j}\right)$ Here, $i=$ counties in the TVA service area, $j=$ states in the TVA service area, ${ }_{\text {FOP }}^{\text {TVA }}$ STATE $_{j}$ refers to the population in state $j$ serviced by TVA, and similarily, POP $_{\text {county }}^{\text {TVA }}$, state $_{j}$ refers to the population in county $i$ and state $j$ which is serviced by TVA. County population is equal to the total county population as reported by the Bureau of the Census for 1975 if the entire county is within the TVA service territory. If the entire county is not within the TVA service territory then the population serviced by TVA in the county is assumed proportional to that fraction of land area in the county that is within the TVA service territory. Land area was approximated from a map of the region showing county borders. A weighting factor is applied to land area which is dependent upon the demography of the county. If population centers in a border county are equally distributed throughout the county the weighting factor equals 1.0. If population centers in a border county tend to be located within the TVA service territory, the weighting factor is greater than 1.0 . Conversely if if population centers tend to be located outside the borders of the TVA service territory, the weighting factor is less than 1.0. Comparing the total population in the TVA region as reported by TVA to that estimated by summing individual county populations using the above procedure reveals only a $1 \%$ difference in the total 1975 TVA population.

Space Heating

The primary end-use demand in the residential sector is space heating, consuming almost $60 \%$ of the energy used in that sector during 1975 . The total number of households in 1975 using natural gas, fuel oil, coal, wood, LPG, electric resistance heat and electric heat pumps for space heating is based on data provided by TVA. There is no data currently available which specifies space heating fuel by region and building type, although the Bureau of the Census does publish data at a national 
leve1.(16) Therefore it was necessary to map the number of households by fuel

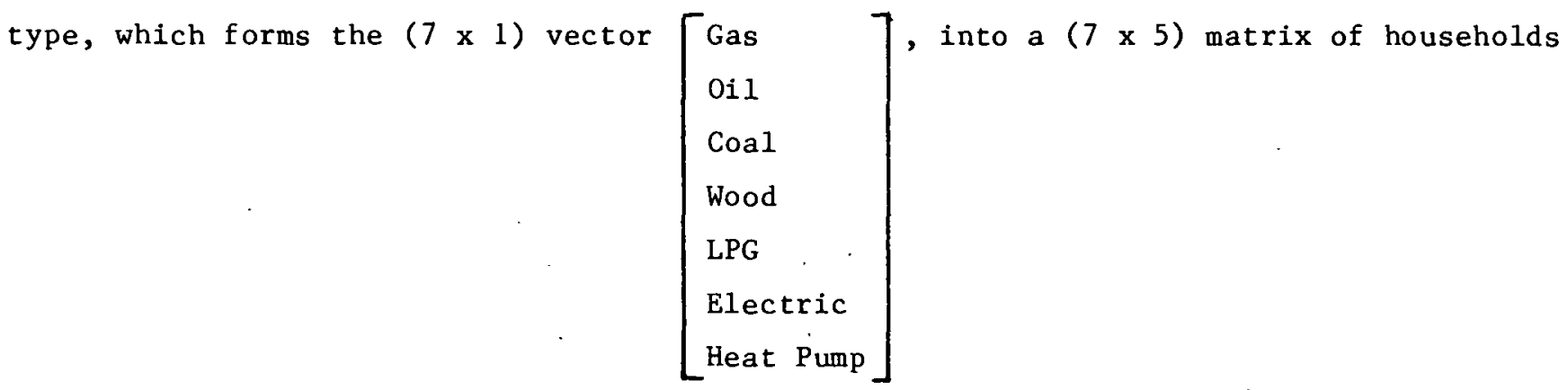

by fuel type and and building type

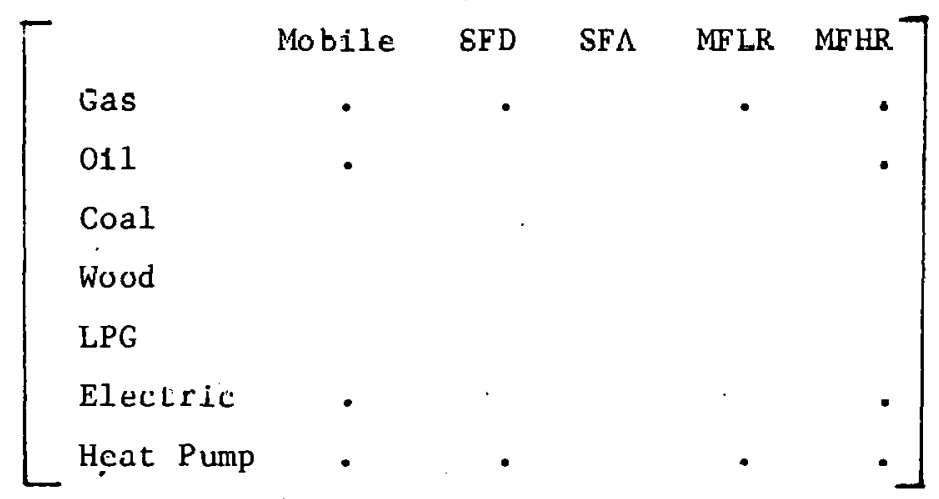

In mapping the $(7 \times 1)$ vector of households by fuel type into the $(7 \times 5)$ matrix of households by fuel and building types it was assumed that all wood is burned in singlefamily detached units and that no coal is burned in mobile homes.

The energy requirement for space heating is proportional to population welghted= average annual heating degree days in the region. Heating degree days in the state of Tennessee are assumed to approximate heating degree days In Lhe TVA region. Energy demand for space heating in residential buildings in LÉlus of basic energy demand (delivered energy $x$ efficiency) is shown in Table II-3.

Table II-3

RTSIDENTIAL EPACE HEATINC

\begin{tabular}{lc}
\hline Building Type & $\begin{array}{c}\text { Encrgy Reg't/Household } \\
\left(10^{6} \text { Btu }\right)\end{array}$ \\
\hline Mublle Humie & 30.5 \\
Eingic-riamily Lotached & 45.8 \\
Single-Family Attached & 29.1 \\
Multi-Family Low Rise & 15.8 \\
Multi-Family High Rise & 9.9 \\
Average & 41.7 \\
\hline
\end{tabular}


The burner efficiency and the relative shell effectiveness for the various fuels that satisfy the basic energy demands specified in the residential space heating fuel mix table are given in Appendix $B$. In computing the basic energy demand, $E=D_{i} \times e_{i}$, the relative efficiency, $e_{i}$, is simply the product of the buxnex efficiency and the relative shell effectiveness. The burner efficiencies for nat'ural gas, fuel oil, coal and electric resistance heat are $.75, .63, .70$ and 1.00 , respectively. No burner loss is assumed for electric resistance heat.

The Seasonal Performance Factor (SPF) for the electric heat pump, 1.60 in the TVA region, is a measure of the of operational efficiency for a specific heat pump system in a given house, under normal climate conditions. This measures all energy input to the system including backup system inputs (e.g., electric resistance heat) relative to the amount of heat actually required for the house. The Coefficient of Pexformance $(\mathrm{COP})$ is a measure of the efficiency of operation for a heat pump based on laboratory tests and is generally greater than the SPF. The terms Coefficient of Performance and Seasonal Performance Factor are used interchangeably in reference to heat pumps throughout this report, although the SPF measurement of efficiency is implied. The burner efficiency for electxicity to residential space heating shown in the Fuel Mix Table in Appendix B (1.027 for 1975) is the product of the burner efficiency for electric resistance heat, 1.00, and the CoP for heat pumps, 1.60 , weighted by the respective inventories.

The apparent relative shell effectiveness reflects construction practices typical of the 1975 inventory and construction practices projected over the reference years. The relative shell effectiveness of an electrically heated home is set at 1.00 in 1975. The shell effectiveness of other buildings reflects reduced insulation and other building practices typical of conventional housing units. Housing units constructed after 1985 are assumed to meet ASHKAE 90 - 75 standards. Retrofitting in nne-half of all residential buildings constructed prior to 1975 is projected such that they meet the ASHRAE 90 - 75 standards by the year 2000 .

The basic energy demands derived for 1975 are escalated in proportion to the projected number of households and the housing mix. The projected fuel mix which satisfies the demand for space heating in 1980,1985 and 2000 is derived from the forecast of electric space heating customers provided by TVA and an extrapolation of recent (1970-1975) changes in the fuel mix. The only enexgy source projected to increase its market penetration in residential space heating is electricity, where the percentage of households using electricity is projected to increase from $43 \%$ in 1975 to $62 \%$ in the year 2000. This includes 435,000 households projected to have 
electric heat pumps in 2000 compared to 60,000 in 1975 . It is assumed that 15,000 new heat pump installations in the residential sector will occur annually over the next twenty-five years. This is equal to the number of new installations that occured in 1976. The number of households using coal to meet their space heating requirements is expected to approach zero by the year 2000 . The percentage of households using oil, wood and LPG to satisfy their heating load is projected to decrease from $18 \%$ in 1975 to $13 \%$ in 2000 , although the absolute number of households will increase from 364,000 to 412,000 households. Natural gas is projected to satisfy the remainder of the residential space heating load, decreasing from $32 \%$ in 1975 to $25 \%$ in 2000 .

A sharp difference is noted when the percentage of households in the TVA region currently using coal (7\%), wood (5\%) and LPG (8\%) relative to that using fuel oil (5\%) is compared with other regions of the U.S. In New England, for example, less than $1 \%$ of the households use coal and wood to meet their space heating demand, while $85 \%$ of the households use fuel oil. Forty-three percent of the housing units have electric space heating in the TVA region compared to about $4 \%$ in New England. This is primarily due to the lower price of electricity in the TVA region, ( $\left.\$ .025 / \mathrm{kWh}^{1}\right)$ compared to the price in New England $(\$ .044 / \mathrm{kWh})$. Air Conditioning

Energy requirements for air conditioning vary regionally with temperature, humidity and cloud cover. Equivalent full load operating hours is a measure of air conditioning energy requirements that more accurately reflects these meteorological variables than cooling degree days which considers only temperature. The annual hours of compressor operation for a properly sized air conditioner are given in Figures II-1 and II-2 for any U.S. location.(41) Taking a point slightly south of the geographical centroid of Tennessee as the approximate population center in the region gives an estimate of equivalent full load operating hours for air conditioners in the region of 1200 hours. A $78^{\circ} \mathrm{F}$ inside temperature is assumed, with one-half of the air conditioners used in conjunction with natural ventilation and one-half the air conditioners operating with no ventilation allowed. Average annual unit energy requirements for air conditioners in the U.S., operating at 1 nก! hours, is $1390 \mathrm{kWh}$ for room units and $3560 \mathrm{kWh}$ for central units. (3) Increasing these unit energy demands by the ratio of operating hours in the region to operating hours in the U.S. results in an annual electric demand in the TVA region of $1668 \mathrm{kWh} /$ unit for room air conditioners and $4272 \mathrm{kWh} / \mathrm{unit}$ for central air-conditioners. The unit basic energy demand shown in the Fuel Mix Table in Appendix $B$ assumes there are 1.47 room air conditioners per household. 1 As of January 1,1975 based on average monthly consumption of $500 \mathrm{kWh}$. (46) 


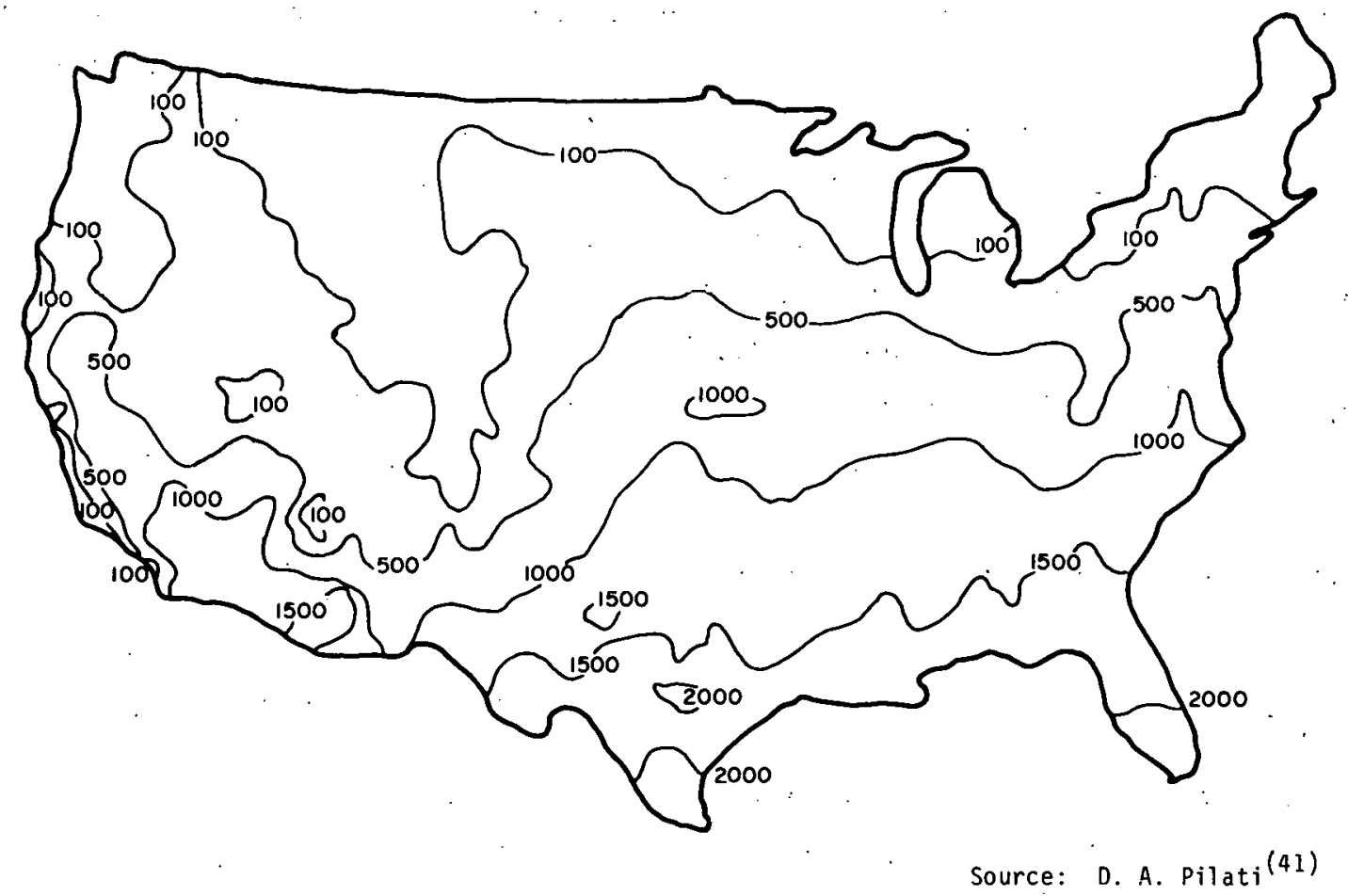

Figure II-1. Annual air-conditioner compressoroperating hours for homes that are also naturally ventillated.

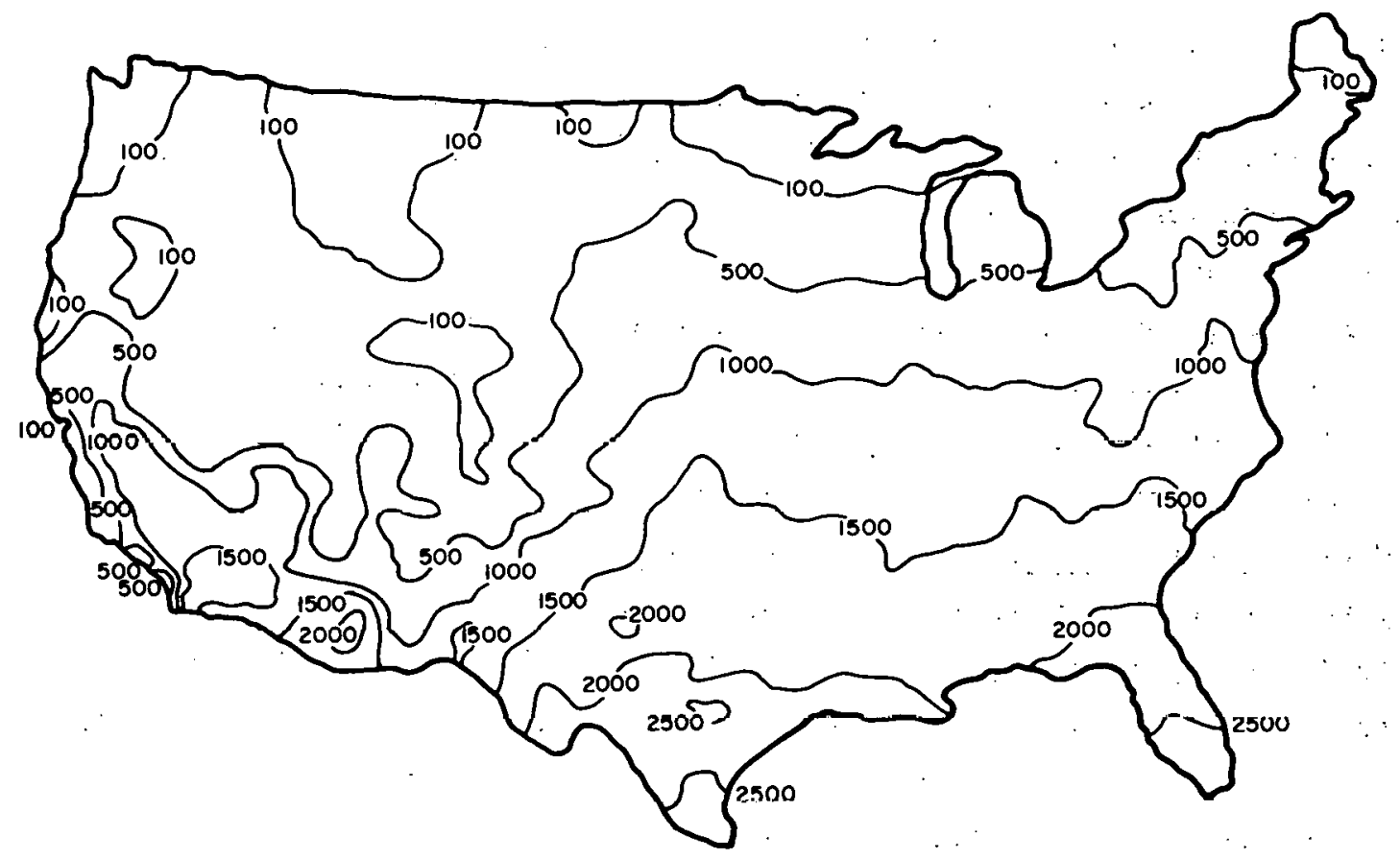

Figure II-2. Annual air-conditioner compressoroperating hours for homes that are not naturally ventillated. 
The coefficient of performance (COP) for currently installed room air conditioners of typical capacity is $1.75 .(41)$ The COP for curxently installed central aix conditionexs of typical capacity is 2.00.(47) The coefficient of performance of all air conditioners is increased to 3.00 by the year 2000 to reflect the use of the more efficient devices that are on the market today.

The current market penetration of air conditioners in the TVA region is dexived fxom 1970 Census of Housing data(2) updated to 1975 using the Annual Housing Survey. (42) The number of air conditioners in the TVA region is computed from state census data weighted by the population serviced by TVA in each state as follows;

$$
\begin{aligned}
& \text { Maxket Penetration of } \mathrm{A} / \mathrm{C} \text { in the TVA Region }=\left(\#_{\mathrm{HH}^{\mathrm{A}}}^{\mathrm{C}}\right)_{\mathrm{TVA}} /\left(\#_{\mathrm{HH}}\right)_{\mathrm{TVA}}=
\end{aligned}
$$

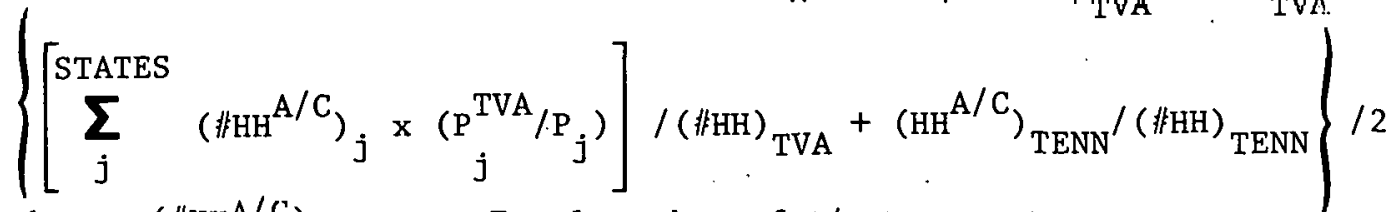

$$
\begin{aligned}
& \text { where, }\left(\#^{\mathrm{HH}^{\mathrm{A}} / \mathrm{C}}\right)_{\text {region }}=\text { Total number of } \mathrm{A} / \mathrm{C} \text {. households in region. } \\
& P_{j} \quad-\text { Tutal population in otate } j \\
& P_{j}{ }^{\text {TVA }}=\text { Population in state } j \text { that is serviced by TVA } \\
& j \quad \text {. = States in TVA sexvice area }
\end{aligned}
$$

The fraction of households having air conditioners in the state of Tennessee (the second term in the above expression) 1s more typical of the TVA region than that fraction computed from individual state data (the first texm in the expression) because of the common price of electricity in the TVA region. Therefore, market penetration in Tennessee is more heavily weighted by inclusion of the second term in equation II-5.

The basic energy demands derived for 1975 are escalated in proportion to market penetration and the number of households projected in the reference years. Virtually all homes are projected to have air conditioners by the year 2000, with central air conditioning dominating the market.

Water Heating, Cooking, Appliances and Lighting

Energy requirements for domestic hot water heating in 1975 are computed from the unit basic energy demand $\left(19.2 \times 10^{6} \mathrm{Btu} / \mathrm{household}\right)(1)$, the market penetration of water heaters $(90 \%)$, and the number of households in the region $(2,025,000$ households). The mix of fuels satisfying the demand for water heating in 1975 are derived from 1970 Census of Housing data updated to 1975 using the Annual Housing Survey. The mix of fuels is estimated from census data for each state weighted 
Table II-4

RESIDENTIAL APPLIANCES --

ENERGY USE AND REGIONAL

MARKET PENETRATION

\begin{tabular}{|c|c|c|c|c|c|}
\hline & Million Btu & & $\begin{array}{l}\text { rket } \\
(\mathrm{Per}\end{array}$ & $\begin{array}{l}\text { etrati } \\
\text { at) }\end{array}$ & \\
\hline & Per Household & 1975 & 1980 & 1985 & 2000 \\
\hline $\begin{array}{l}\text { Refrigerators, } \\
\text { Lighting, \& }\end{array}$ & & & & . & \\
\hline Small Appliances & 7.9 & 100 & 104 & 106 & 113 \\
\hline Dishwasher & 1.2 & 29 & 43 & 56 & 100 \\
\hline Electric Dryer & 3.2 & 41 & 49 & 56 & 79 \\
\hline Gas Dryer & 8.8 & 12 & 11 & 10 & 7 \\
\hline Television & 1.5 & 143 & 151 & 160 & 186 \\
\hline Food Freezer & 4.6 & 42 & 47 & 51 & 65 \\
\hline Clothes Washer & 0.3 & 75 & 77 & 79 & 86 \\
\hline New Uses & 1.6 & 0 & 29 & 46 & 100 \\
\hline TOTAL & 29.1 & - & - & - & - \\
\hline AVERAGE & - & 51 & 56 & 60 & 72 \\
\hline
\end{tabular}

${ }^{(1)}$ Source: Reference 1. 
by population using a methodology analogous to the one used to compute the market penetration of air conditioners in the region [see Eq. (II-5)]. The basic energy demand derived for 1975 is escalated in proportion to the number of households and market penetration projected in the reference years. Electric hot water heating is projected to continue dominating the market such that over three quarters of the households use electricity to meet their domestic hot water energy requirements by 2000. This implies that all additions to the housing inventory using electricity to meet their space heating requirements also use electricity for water heating. Moreover, approximately 60,000 new additions to the housing inventory using natural gas to meet their space heating requirements will use electricity for domestic hot wher heating.

Energy requirements for cooking in the residential sector are computed from the unit basic energy demand ( $3.9 \times 10^{6} \mathrm{Btu} /$ household) and the number of households in the region. The mix of fuels satisfying the demand for cooking in the residential sector in 1975 are derived from 1970 Census of Housing data updated to 1975 using the Annual Housing Survey. The mix of fuels is estimated from census data for each state in the region weighted by population using a methodology analogous to the one used to compute the market penetration of air conditioners in the region[see Eq. (II-5)]. The basic energy demand derived for 1975 is escalated in proportion to the number of households projected in the reference years. The fuel fraction, $f_{i}$, is projected in proportion to the increasing market penetration of electric ranges and the decreasing use of natural gas, LPG, coal and wood for cooking. The shift toward electric ranges which occurred from 1970 to 1975 is assumed to continue such that by the year 2000 electric ranges have completely saturated the market.

The residential lighting and appliance category accounts for energy consumed by refrigerators, dishwashers, electric dryers, gas dryers, televisions, food freezers, clothes washers, lighting, and miscellaneous small appliances. Energy requirements in this demand category are computed from the unit basic energy demand for each appliance shown in Table II-4, the market penetration of each appliance, and the number of households in the region. The current market penetration of the various appliances in the TVA region is derived from fuels and appliance data for each state from the 1970 Census of Housing(2) updated to 1975(42) as follows:

Market Penetration of Appliance " $k$ " in the TVA Region =

$$
\left(\text { \#HH }^{\mathrm{APL}}\right)_{\mathrm{TVA}} /(\text { 非H })_{\mathrm{TVA}}=
$$

$\left[\sum_{j}^{\text {STATES }}\left(\right.\right.$ \#HH $\left.\left.^{\mathrm{APL}}{ }^{\mathrm{A}}\right) \mathrm{j} \times\left(\mathrm{Pj}^{\mathrm{TVA} / \mathrm{P} j}\right)\right] /(\text { 非H })_{\mathrm{TVA}}$ 
where, ( \#HH $_{\text {TVA }} \quad=$ Total number of households in the TVA region.

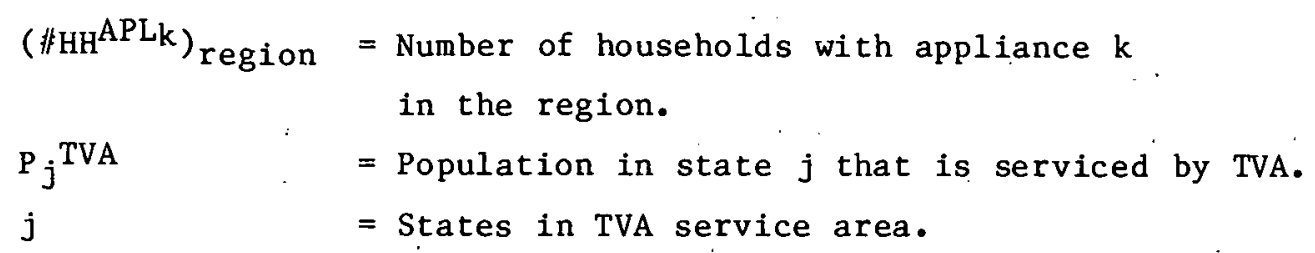

The basic energy demand derived for 1975 is escalated in proportion to the number of households and the market penetration projected in the reference years. To allow for the introduction of new electrical devices not yet in use, it is assumed that these devices will consume as much energy in 2000 as small appliances per household did in $1970,1.6 \times 10^{6} \mathrm{Btu} / \mathrm{household}$.

COMMERCIAL SECTOR

The commercial sector incorporates a wide range of activities which for the purposes of this study are disaggregated into two broad categories: 1) buildings, and 2) agriculture and mining. A methodology similar to the one followed in the residential sector is used to compute energy consumption in commercial buildings. Energy is consumed in commercial buildings for space conditioning, water heating, cooking, lighting, refrigeration, computers and other electrical appliances. Outdoor lighting is also included in this sector. Following the section of this report on commercial buildings, energy consumption in agriculture and mining is discussed. Commercial Buildings

Commercial buildings serve a broad range of functions which include:

- Retail Stores

- Warehouses

- Offices and Banks

- Service Stations

- Libraries and Museums

- Educational Buildings

- Hospitals

- Government Buildings

- Churches

- Passenger and Freight Terminals

- Other Miscellaneous Nonresidential Buildings

- Dormitories, Motels, and Hotels 
These buildings have widely varying energy requirements, but in order to develop unit energy requirements for the commexcial inventory in a consistent fashion the following building definitions were established:

- Office buildings - include offices, banks and public buildings (15\% of commexcial inventory).

- Retail Buildings - include stores, other mercantile buildings, garages and service stations (18\% of commercial inventory).
- Schools
- Hospitals
- Other

- (26\% of commercial inventory).

- (7\% of commercial inventory)

- includes warehnuses (22\% of commerrial inventory), churches, amusement and recreational buildings, transportation terminals, and other miscellaneous nonresidential buildings ( $12 \%$ of commerclal inventory).

The commercial inventory in the region, 680 million square feet or 108 square feet per capita, is from data provided by TVA for 1975 and appears to be consistent with commexcial floor space per capita estimates for the East South Central census region. (30) The commercial inventory is classified by building type as shown in Table II-5, according to key economic variables, in proportion to the commexcial inventory in the South. (1)

$$
\text { Table II }-5
$$

\begin{tabular}{lc} 
COMMERCIAL INVENTORY IN THE TVA REGION - \\
$\begin{array}{l}\text { (Millione } \\
\text { equare foot) }\end{array}$ \\
\hline Offices & 1075 \\
Retail & 123 \\
Schools & 174 \\
llospitals & 47. \\
Other & 234 \\
Total & 680 \\
\hline
\end{tabular}

The total commercial inventory in the l'VA region is projected to 1980, 1985 and 2000 in proportion to output in the services sector from the Brookhaven National Laboratory input-output model, adjusted by regional earnings. The following methodology is used to project the commercial inventory in the region. First, exogenously specified primary energy prices and quantities are input into the Data Resources Incorporated (DRI) 10 sector general equilibrium macroeconomic model. Then using aggregate economic and 
energy estimates from the DRI model, the BNL input-output model solves for energy service levels and output in each of the 110 sectors. (40) The commercial inventory in the TVA region is then calculated from U.S. output in the services sector from the I/O model, adjusted by regional earnings as follows:

[TVA COMMERCIAL INVENTORY $]_{t}=$

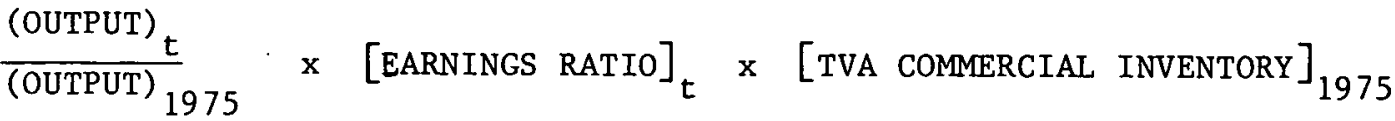

where, OUTPUT $=$ Dollars of output in the services sector from the I/O model for the U.S.

$t=$ Projection year -- 1980, 1985, 2000

The regional adjustment or "Earnings Ratio" is computed as the ratio of projected regional earnings in the commexcial sector to projected U.S. earnings in the commexcial sector, normalized to 1970 . $[\text { EARNINGS RATIO }]_{\mathrm{t}}=\left(\frac{\mathrm{E}_{\text {TVA }}}{\mathrm{E}_{\mathrm{U} . \mathrm{S} .}}\right)_{\mathrm{t}} /\left(\frac{\mathrm{E}_{\mathrm{TVA}}}{\mathrm{E}_{\mathrm{U} . \mathrm{S} .}}\right)_{1970}$

where $E=$ Earnings in the commercial sector which includes a) wholesale and retail trade, b) finance, insurance and real estate, c) services, and d) federal, state and local government. $t=$ Projection year -- 1980, 1985, 2000 .

Earnings projections for the U.S. and by state are from the 1972 OBERS Projections of Regional Economic Activity in the U.S. (17) developed by the Bureau of Economic Analysis for the Water Resources Council. These projections are based on the 1972 Series E population projections from the Bureau of the Census. Earnings in the TVA region are dexived from earnings in each of the states by assuming earnings is proportional to that fxaction of the population which is sexviced by TVA in each of the states:

[EARNINGS $]_{\text {TVA }}=$

$$
\sum_{j}^{\text {STATE }}\left[(\text { EARNINGS }) j^{\mathbf{x}} \times \text { POPTVA }_{\text {STATE }} \text { /POPSTATE } j\right]
$$

where $j$ equals the states in the TVA service arca. POPSTATEj rcfers to the total population in statej. POPTVA refers to the population in state $j$ serviced by TVA and is dexived from the serviced by TVA, as previously defined in Eq. (II-4). 
Energy requirements for space heating in commercial buildings is proportional to population weighted heating degree days in the region and is derived from unit energy demands for five building categories--offices, retail, schools, hospitals and other as shown in Table II-6. The average energy requirement per square foot is 23,000 $\mathrm{Btu} / \mathrm{sq}$ ft as shown in the Fuel Mix Table for commercial space heating. The mix of fuels satisfying this demand was estimated relative to the mix of fuels in residential space heating. Over one-half of the energy requirements for space heating in comercial buildings are projected to be met by electricity by 2000 compared to an estimated $25 \%$ in 1975. Electric heat pumps are projected to meet the demand for space conditioning in an estimated 200 million square feet of commercial buildings by the year 2000 , reducing the demand for electricity in those buildings by a factor of over one-third relative to conventional electric heat. The fraction of the commercial inventory heated by natural gas, fuel oil, LPG, coal and wood is projected to decrease over the reference years. The energy requirement for air conditioning in commercial buildings is proportional to equivalent full load operating hours in the TVA region (1200 hours) and is computed from the unit energy demand for commercial air conditioning by building type shown in Table II-6. The unit energy demand for commercial air conditioning in the region is a function of the unit demand in the South(1) and the ratio of operating hours in the TVA region to operating hours in the South. The average energy requirements per square foot of commercial floor space in the region is $53,500 \mathrm{Btu} / \mathrm{sq} \mathrm{ft}$ as shown in the fuel mix table for commercial air conditioning. This unit demand is in terms of basic energy demand and must be divided by the COP to obtain delivered electricity. The market penetration for air conditioning is projected to reach $100 \%$ by the year 2000 . The energy requirement for water heating in commercial buildings is a function of the unit energy demand for water heating as shown in Table II-6 and the commercial inventory. The mix of fuels satisfying this demand is estimated relative to residential water heating, with electricity projected to dominate the market over the reference years.

Energy demands for commercial cooking are a function of the number of meals served and the energy required to cook a meal. The energy required to cook a meal is assumed to be $75 \%$ of the energy demand in the residential sector. The number of meals served is proportional to the population and the fraction of all meals eaten in commercial establishments. In 1975 an estimated $20 \%$ of all meals were eaten in commercial establishments and this is projected to increase to $25 \%$ by the year 2000 . 
Table II-6

UNIT ENERGY DEMAND IN COMMERCIAL BUILDINGS

THE TENNESSEE VALLEY AUTHORITY - 1975

\begin{tabular}{|c|c|c|c|c|c|c|c|}
\hline . & & & Delivered & Energy $\left(10^{3}\right.$ & $\mathrm{Btu} / \mathrm{Sq}$. Ft./Year) & & \\
\hline Building Type & $\begin{array}{l}\text { Space } \\
\text { Heating } \\
\end{array}$ & $\begin{array}{l}\text { Atr } \\
\text { Conditioning } \\
\end{array}$ & $\begin{array}{l}\text { Water } \\
\text { Heating }\end{array}$ & Lighting & Refrigeration & Appliances & $\begin{array}{l}\text { HVA/C Auxiliary } \\
\text { Equipment }\end{array}$ \\
\hline Office Buildings & 32.0 & 20.4 & 3.4 & 25.5 & - & 6.1 & 7.5 \\
\hline Retail Establishments & 19.0 & 23.4 & 1.7 & 27.2 & 30.4 & 6.8 & 12.2 \\
\hline Schools & 24.0 & 16.3 & 3.4 & 22.1 & - & 5.1 & 11.2 \\
\hline Hospitals & 25.0 & 27.2 & $17 \vdots 0$ & 51.0 & - & 20.3 & 59.6 \\
\hline
\end{tabular}


The energy demand in commercial buildings for lighting, refrigeration, HVA/C auxiliary equipment, and miscellaneous electrical appliances including computers is a function of the unit energy demand in each of these categories as shown in Table II-6 and the commercial inventory. The energy requirement for refrigeration that relates to food and beverage distribution is estimated to be 37.5 billion kilowatt hours in the U.S.(1) This results in an energy demand for refrigeration of $30,400 \mathrm{Btu}$ per square foot in the retail inventory. This is projected to increase by a factor of two by the year 2000. The minor energy requirements for refrigeration in offices, schools, and hospitals are included with miscellaneous electrical appliances. The consumption of electricity by miscellaneous electrical appliances including computers is projected to increase by a factor of two from 7,200 Btu/sq $\mathrm{ft}$ in 1975 to $14,400 \mathrm{Btu} / \mathrm{sq} \mathrm{ft}$ in 2000 .

Consumption of electricity for outdoor lighting in the TVA region was $867 \mathrm{~m} 11-$ lion kilowatt-hours in $1975(23)$ and this is projected to increase by more than a factor of three to 2784 million kilowatt-hours by 2000 .

Agxiculture and Mining

Agricultural uses of energy associated with growing crops and raising livestock are currently estimated to be 2014 trillion Btu's in the U.S.(13) Energy consumption associated with the marketing, distribution and processing of foods as well as energy consumed by farmers for residential uses are not accounted for in this estimate. Included in this estimate are the contributions to energy consumption by such activities as plowing, planting, irrigation, harvesting, crop drying, livestock handling, feed handling and space conditioning, in addition to such indirect energy uses as fertilizex and pesticide production. Petrochemlcals used to manufacture fertillzers and pesticides account for 716 trillion Btu's or $36 \%$ of the 2014 trillion Btu's of energy used in agricultural production as shown in Table II-7. In the analytic framework of the Reference Energy System, feedstocks used as raw material input in the manfacture of fertilizers and pesticides are included in the industxial sector of the RES. Gasoline and diesel fuel consumed for business purposes by automobiles, trucks and other farm machinery account for an additional 708 trillion Btu's or $35 \%$ of the 2014 trillion Btu's used in agricultural produrtion. These motor fuels as well as those used for non-business purposes by farmers are accounted for in the transportation sector of the Reference Energy System. The remaining 590 trillion Btu's of energy associated with agricultural production is disaggregated by fuel type, as shown in the Agriculture Fuel Mix Table in Appendix B, 
Table II-7

FUNCTIONAL USE OF ENERGY IN THE U.S. FOR AGRICULTURAL PRODUCTION, 1974*

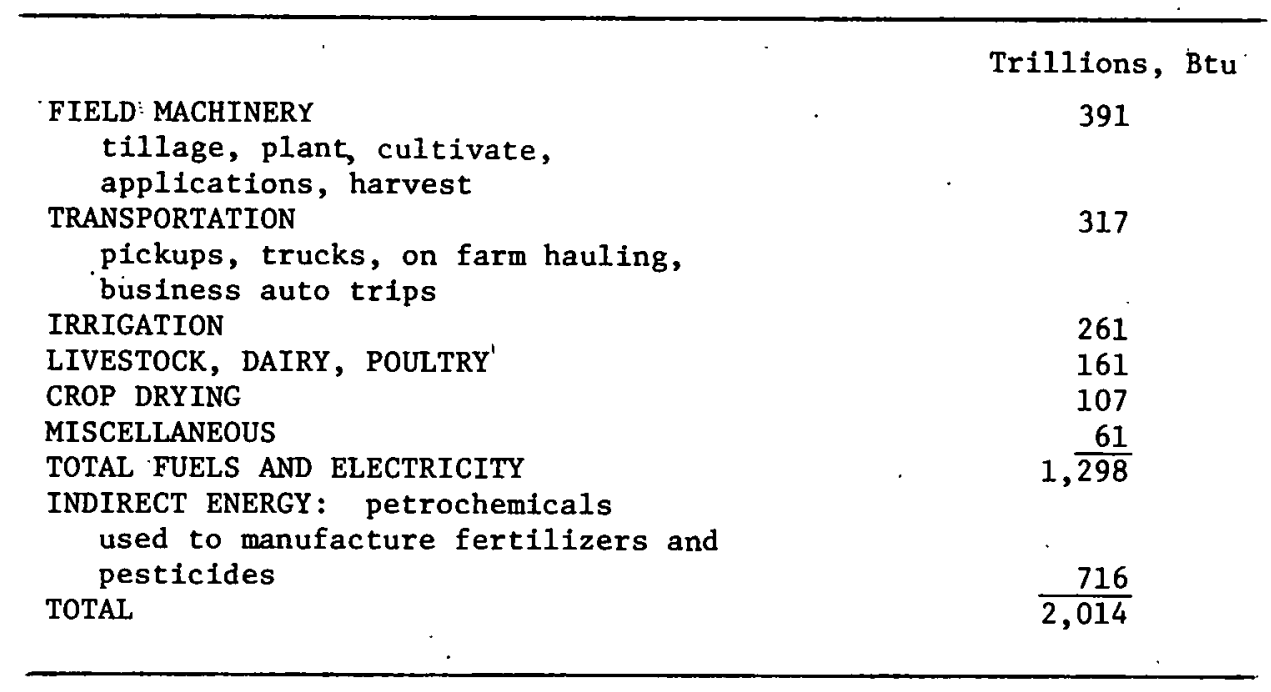

*Source: U.S. Department of Agriculture, Energy and U.S.
Agriculture: 1974 Data Base

Table II-8

FUELS AND ELECTRICITY USED IN AGRICULTURAL PRODUCTION, $1974 *$

\begin{tabular}{lr}
\hline Gasoline & 3.7 billion gal. \\
Diesel Fuel & 2.6 billion gal. \\
Natural Gas & 164 billion cu. ft. \\
LP Gas & 1.5 billion gal. \\
Electricity & 32 billion kwh \\
Fuel 0il & 304 million gal. \\
Coal & 33,000 tons \\
\hline
\end{tabular}

*Source: U.S. Dejartment of Agriculture, 13 Fnergy and U.S.
Agriculture: 1974 Data Base. 
and regionalized from national totals by assuming energy demand in the TVA region is proportional to farm acreage. The energy flows shown in this demand category are those associated with on-the-farm operations excluding transportation and fertilizer production, as previously noted.

The basic energy demand derived for agriculture is escalated in proportion to projected output in the agriculture sector of the BNL input-output model for the U.S., adjusted by regional earnings. This methodology is analogous to the one followed in the commercial sector, with commercial sector output replaced by agricultural sector output as follows:

TVA [AGRICULTURAL OUTPUT $]_{t}=$

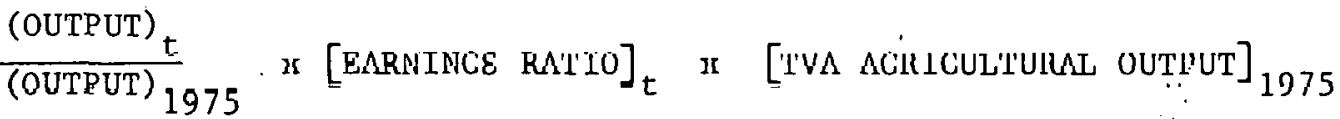

where, output = dollars of output in the agriculture sector from the $I / 0$ model for the U.S.

$$
t \quad=\text { Projection year--1980, 1985, } 2000 .
$$

The Earnings Ratio is given in Eqs. (II-8) and (II-9) for the commercial sector where earnings in this sector is redefined to be earnings in agriculture, forestries and fisheries from OBERS Projections of Regional Economic Activity. (17) Output in the agriculture sector from the BNL input-output model for the U.S. increases at an annual rate of $3.5 \%$ between 1985 and 2000 compared to $2.8 \%$ in the TVA region. This regional variation in agricultural output reflects the decreasing proportion of earnings projected to originate in the region by the year 2000 . Earnings in agriculture is projected to increase at an annual rate of $0.9 \%$ in the U.S. compared to $0.7 \%$ in the TVA region.

Mineral industries in the TVA region are primarily engaged in the mining of bituminous coal and lignite, the nonferrous metal ores bauxite and zinc, and the mining and quarrying of the nonmetallic minerals stone, clay and phosphate rock. Consumption of energy in the IVA region is derived from value added for these mineral industries. Value added is estimated for the minerals mined in the region using the Census of Mineral Industries.(38) Assuming that energy demand per dollar of value added is regionally independent, consumption of energy in the TVA region is estimated as a function of value added and energy consumption in the U.S. for each of the mineral industries noted above.

Consumption of energy for mining is escalated in proportion to projected output in the mining sector of the BNL input-output model for the U.S., adjusted by regional earnings. This methodology is analogous to that followed in the commercial and agricultural sectors. 
TVA MINING OUTPUT] $]_{t}=$

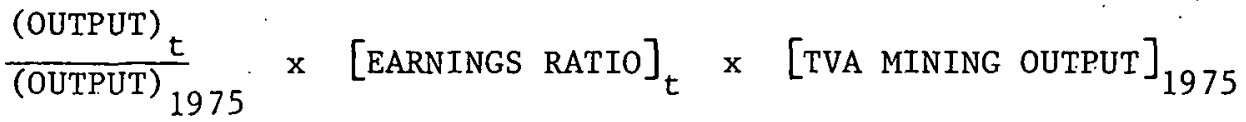

(II-11)

where, OUTPUT $=$ Dollars of output in the mining sector from the $1 / 0$ model for the U. S.

$t=$ Projection year--1980, 1985, 2000 .

The Earnings. Ratio is given in Eqs. (II-8) and (II-9) for the commercial sector where earnings in this sector is redefined to be earnings in mining from OBERS Projections of Regional Economic Activity. Output in the mining sector of the BNL inputoutput model for the U.S. increases at $3.2 \%$ between 1985 and 2000 compared to $4.5 \%$ in the TVA region. This difference appears reasonable in view of the dominant role coal mining plays in the region and its projected growth relative to other mining in the nation.

INDUSTRIAL SECTOR

The industrial sector has been disaggregated into severai major energy intensive industries, including aluminium, steel, petrochemicals and uranium enrichment; remaining industrial energy requirements (excluding petroleum refining) are included in the demand categories industrial process heat and industrial electric drive. Consumption of fuels in these demand categories is initially projected in proportion to industrial activity in the United States, and then regionalized based upon earnings in manufacturing as follows:

[TVA INDUSTRIAL ACTIVITY $]_{i, t}=$

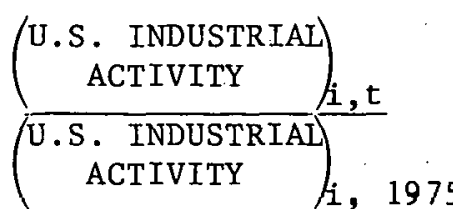

where,

$$
\begin{aligned}
\text { (INDUSTRIAL ACTIVITY) } i, t_{t} & =\text { Activity in manufacturing industry } i \text { in year } t . \\
i & =\text { Manufacturing industries } 1, \ldots, n . \\
t & =\text { Projection years--1980; } 1985,2000 .
\end{aligned}
$$

and

$$
\left[\text { EARNINGS RATIO }_{i, t}=\left(\frac{E_{\text {TVA }}}{E_{\text {U.S. }}}\right)_{1, t} /\left(\frac{E_{\text {TVA }}}{E_{\text {U.S. }}}\right)_{1,1970}:\right.
$$

where, $(E)_{i, t}=$ Earnings in industry $i$ in period $t$.

$i=$ Manuacturing industries $1, \ldots, n$.

$t=$ Projection year- $-1980,1985,2000$. 
Earnings projections for the U.S. and by state are from the 1972 OBERS Projections of Regional Economic Activity in the U.S. (17) Earnings in the TVA region, ETVA, are derived from earnings in each state serviced by TVA by assuming earnings is proportional to population as given in Eq. (II-9).

Aluminum

Electric power is the major form of energy used to produce primary aluminum and is required in the electrolysis of alumina. The electrolytic efficiency of this process is based on a minimum theoretical requirement of 27.3 million Btu per ton. Oxidation of carbon at the anode is accounted for in the losses to coal. Secondary recovery from scrap is less energy intensive than primary production and is projected to represent a growing share of the market. This is expected to increase from $20 \%$ of total production in 1975 to $33 \%$ by the year 2000 , thus decreasing energy consumption per pound of aluminum produced. It is estimated that 1144 million pounds of primary aluminum was produced in 1975 at the four major plants located in the region. This estimate was derived from plant capacity data by assuming that the average capacity factor for plants in the region is equal to the average capacity factor in the United States (79\%). (8) In addition to primary production, 289 million pounds of aluminum was produced from scrap. This estimate assumes that the fraction of aluminum produced from scrap in the region is equal to the fraction of aluminum produced from scrap in the U.S. Total domestic production of aluminum is projected to increase at $5.6 \%$ per year to 1985 and $4.9 \%$ per year thereafter. $(18,19)$ Production in the TVA region is projected in proportion to domestic production, adjusted by regional earnings in total manufacturing [see Eqs. (II-12) and (II-13)]. Aluminum production over the fifteen year period from 1985 to 2000 is projected to grow at an average annual rate of $5.5 \%$ in the TVA region versus $4.9 \%$ in the U.S. This difference is consistent with the higher growth in manufacturing earnings projected for the region, $3.5 \%$, compared to $2.9 \%$ in the U.S.

Stee1

The primary metals industry consumed the largest share of energy used in the U.S. industrial sector, with iron and steel accounting for most of this consumption. The principal uses of natural gas and fuel oil in the steel industry are in heating and annealing furnaces and in open hearth furnaces, which are declining in number. Electric power is used in the steel industry for driving mills, forges, process lines, and in the steelmaking process itself. The quantity of electric power required in the steelmaking process is highly dependent upon the type of furnace uti- 
lized (open hearth, basic oxygen, or electric furnace). From an ad hoc survey of the major steel producers in the region and plant capacity data published by the American Iron and Steel Institute, it has been estimated that 383,400 tons of steel were produced in 1975 using the electric furnace. Considering the low cost of electricity, the lack of blast furnaces to produce pig iron and the minor role of the steel industry in the region, the electric furnace is projected to continue dominating the steelmaking process in the TVA area. Scrap metal is the primary raw material used in the electric furnace with essentially no pig iron required. Requirements for electric power in the electric furnace are 675 kilowatt-hours per ton of steel produced. Projections of steel production in the region are proportional to BNL estimates of steel production in the U.S. (27), adjusted by regional earnings in the primary metals industry [see Eqs. (II-12) and (II-13)].

Petrochemicals

Hydrocarbons derived from natural gas and crude oil, including natural gas itself, natural gas liquids, naphtha and refinery gas serve as the raw material basis for production of most organic chemicals. Coal and coal tar are still used as a raw material in the production of certain aromatic compounds. Historically, the mix of raw materials supplying the chemical industry has shifted from coal to oil and gas. This trend is not expected to continue as coal becomes more readily available relative to oil and gas. Regional demand for hydrocarbons as a petrochemical feedstock in 1975 is assumed to be proportional to value added in the chemicals and allied products industry (SIC-28). Value added in the TVA service area is estimated from 1972 Census of Manufacturing data. (9) The mix of resources supplying the petrochemical industry is assumed to be proportional to the mix of resources in the East South Central Census region. (30) Demand for petrochemical feedstocks is escalated in proportion to projected output in the chemical and allied products sector of the BNL input-output model ${ }^{l}$ for the U.S., adjusted by regional earnings in SIC-28. This projection methodology is analogous to that followed in the commercial sector [see Eqs. (II-7), (II-8), and (II-9)]. Output in the chemicals and allied products sector of the BNL input-output model for the U.S. increases at an annual rate of $4.0 \%$ between 1985 and 2000 compared to $4.1 \%$ in the TVA region. The slightly higher growth rate projected for the region reflects the higher earnings in the chemical industry that is projected for the area relative to the rest of the nation.

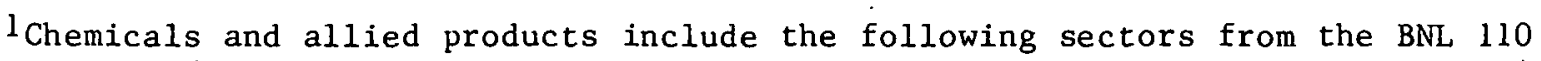
sector I/O model: chemicals and selected chemical products; plastics and synthetic materials; drugs, cleaning and toilet preparations; and paints and allied products. 
Uranium Enxichment

The Tennessee Valley Authoxity supplied almost 22 billion kilowatt-hours of electricity in 1975 to the two federally operated gaseous diffusion uranium enrichment plants located in Paducah, Kentucky and Oak Ridge, Tennessee. Sales to these federal agencies are projected to increase by almost a factor of two, to 40 billion kilowatthours by 1980 , and then level off at that demand through the year 2000.(23)

Electric Drive

Electricity sales to industry by the Tennessee Valley Authority includes sales to municipalities and cooperatives, federal agencies, and sales directly served to industry. All electricity used in the industrial sector and not consumed in the aluminum, steel and uranium enrichment industries is accounted for in the category Miscellaneous Electric Drive as shown in the Fuel Mix Table in Appendix B for 1975. Directly served industry sales and sales to federal agencies are escalated to the year 2000 from data provided by the Tennessee Valley Aüthority. Electricity sales to industry through municipalities and cooperatives is projected by TVA through 1985 and estimated by BNL from 1985 to the year 2000.

\section{Process Heat}

All energy used for fuel in the industrial sector which is not consumed in the aluminum, steel, petrochemical, uranium enrichment or petroleum refining industries is accounted for in the category industrial process heal. To estimate demand for energy in this category overall energy requirements by induslcy are initially estimated. Industrial process heat then represents the balance of unaccounted fuels in the industrial sector after all other end uses are accounted for. Total energy requixements in the industrial sector are assumed to be proportional to regional value added in manutacturing. Thus,

$$
(\text { ENERGY) })_{\text {TVA }}=\left(\frac{\text { ENERGY }}{\text { VA }}\right)_{\text {ESC }} \times \quad{ }^{(V A)}{ }_{\text {TVA }}
$$

and, $(\mathrm{VA})_{\mathrm{TVA}}=\sum_{i}\left(\mathrm{VA}_{i} \times \mathrm{POP}_{i}^{\mathrm{TVA}} / \mathrm{POP}_{i}\right)^{\mathrm{T}}$

where, ENERGY = Industrial energy consumption

$$
\begin{aligned}
\mathrm{VA} & =\text { Dollars of value added in manutacturing } \\
\mathrm{POP}_{i} & =\text { Population in county } i \\
i & =\text { Counties in the TVA region. }
\end{aligned}
$$

$\mathrm{POP}_{i}$ TVA equals the population in county $i$ that is serviced by TVA and is estimated from Bureau of the Census data (for additional details on its derivation refer to the residential sector at the beginning of this section).

- ': The ratio of industrial energy consumption per dollar of value added in manufacturing in the east south central census region, (ENERGY/VA) ESC, is assumed to 
approximate energy consumption per dollar of value added in the TVA region. The energy ințensiveness of industries in the east south central census region more closely typifies those industries in the TVA region than does the overall mix of industries in the U.S. This can be attributed, in part, to the common price of electricity in the two regions relative to the U.S. as shown in Table II-9. The fact that energy-intensive industries, such as aluminum and uranium enrichment, are located in the region has traditionally been attributed to the low cost of electric power. The average price of electricity to large light and power customers during 1975 was $1.59 \$ / \mathrm{kWh}$ in the east south central census region and 1.54 $\$ / \mathrm{kWh}$ in the state of Tennessee, $15 \%$ to $20 \% 1$ ess than the average price of electricity to large light and power customers in the U.S., $1.92 \$ / \mathrm{kWh}$. The energy intensiveness of industry in the east south central census region (as measured in terms of industrial energy consumption per dollar of value added in manufacturing) was $46.9 \times 10^{3} \mathrm{Btu} / \$$ in 1975 compared to $39.8 \times 10^{3} \mathrm{Btu} / \$$ in the nation reflecting the differential in the price of electricity between the two regions. The mix of fuels in the. TVA region is assumed to be the same as the mix of fuels in Tennessee. 263 trillion Btu's of energy was consumed in the industrial process heat category in 1975, in addition to the fuels and electric energy consumed by industry in those categories previously noted. The fuel fraction, $f_{i}$, shown in the Fuel Mix Table for industrial process heat indicates that $68 \%$ of the energy consumed in this category was in the form of natural gas.

Energy consumed in the industrial process heat category is escalated at an annual growth rate of $4.8 \%$ from 1975 to $1980,3.4 \%$ from 1980 to 1985 and $3.2 \%$ thereafter. This growth rate is derived from (1) the historical ratio of U.S. energy consumption in the industrial sector to gross national product (GNP), and (2) the ratio of TVA to U.S. earnings in manufacturing in the projected year divided by the ratio of TVA to U.S. earnings in 1970 [see Eqs. (II-12) and (II-13)]. Energy consumed in the industrial sector 1n the U.S. between 1960 and 1972 grew at $2.0 \%$ per year, whereas GNP grew at $3.4 \%$ per year over the same period (see Figure II-3). The ratio of industrial energy consumption to GNP (in constant dollars) has been declining over time and is projected to continue to decline through 2000 . A least squares fit to Energy-GNP data over the period 1960-1972 results in the following equation:

$$
\begin{aligned}
& (\text { ENERGY/GNP })_{t}=(\text { ENERGY } / G N P)_{1960}+M(t-1960) \\
& \text { where, ENERGY/GNP } 1960=32,453 \mathrm{Btu} / \text { \$GNP } \\
& \qquad \begin{array}{l}
\mathrm{M}=-241 \mathrm{Btu} / \text { \$GNP per year } \\
\mathrm{t}=1960, \ldots, 1972
\end{array}
\end{aligned}
$$


Table II-9

REGIONAL VARIATIONS IN ENERGY PER VALUE ADDED

AND THE PRICE OF ELECTRICITY

\begin{tabular}{lcc}
\hline & $\begin{array}{c}\text { Industrial Energy Consumption } \\
\text { Per Dollar of Value Added } \\
\text { in Manufacturing }\left(10^{3} \text { Btu/\$) }\right.\end{array}$ & $\begin{array}{c}\text { Price of Electricity to Large } \\
\text { Light \& Power (c/kWh) }\end{array}$ \\
\hline $\begin{array}{l}\text { East South Central } \\
\text { Census Region }\end{array}$ & 46.9 & 1.59 \\
$\begin{array}{l}\text { Tennessee } \\
\text { United States }\end{array}$ & - & 1.54 \\
\hline
\end{tabular}

Table II-10

INDUSTRIAL ENERGY CONSUMPTION VS. GNP IN

THE UNITED STATES

\begin{tabular}{lccc}
\hline Year & $\begin{array}{c}\text { Industrial Use of } \\
\text { Energy }(1015 \text { Btu) }\end{array}$ & $\begin{array}{c}\text { GNP } \\
\text { (Billions of } 1958 \$)\end{array}$ & $\begin{array}{c}\text { Energy/GNP } \\
\left(10^{3} \mathrm{Btu} / \$\right)\end{array}$ \\
\hline 1975 & 21.5 & 816 & 26.3 \\
1980 & 26.4 & 955 & 27.6 \\
1985 & 29.5 & 1118 & 26.4 \\
2000 & 40.9 & 1793 & 22.8 \\
Rate of Cliange & & & -241.0 \\
Per Year & $2.6 \%$ & $3.2 \%$ & \\
\hline
\end{tabular}




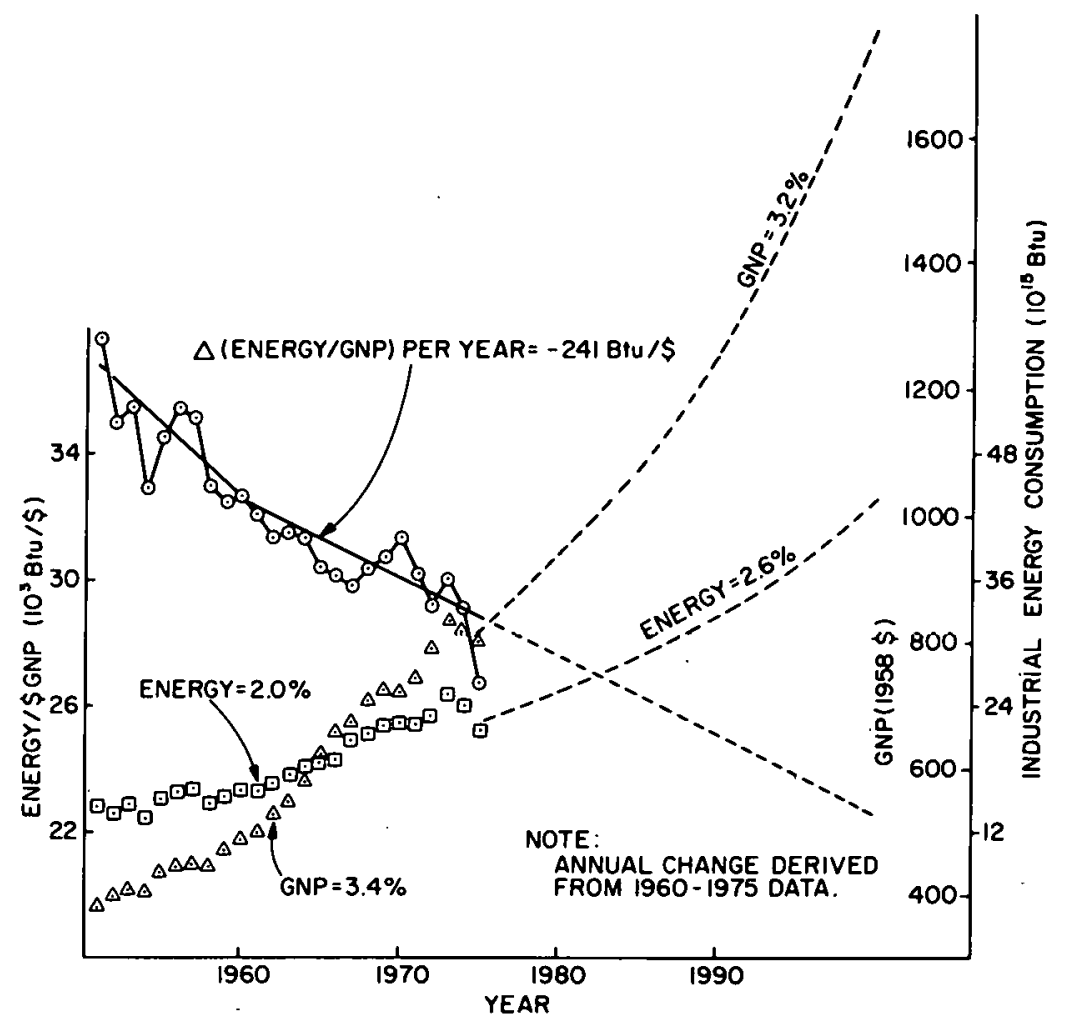

Figure II-3. Industrial energy consumption relative to GNP, 1951-2000. 
Thus, if it is assumed that the ratio of industrial energy consumption to GNP continues to decline as it has since 1960, at the rate of 241 Btu per dollar of GNP per year, then the following equation can be used to project the ENERGY/GNP ratio in 1980, 1985 and 2000:

$$
(\text { ENERGY/GNP })_{t}=32,453 \mathrm{Btu} / \$ \mathrm{GNP}-241 \frac{\mathrm{Btu} / \$ \mathrm{GNP}}{\text { Year }}(t-1960)
$$

where, $t=1980, \ldots, 2000$

Since GNP is projected to increase at an annual rate of $3.2 \%$ over the 1975 to 2000 time period, the level of energy consumption by industry in the U.S. can be projected to time period " $t$ " using the following equation:

$(\text { ENERGY })_{t}=(E N E R G Y / G N P)_{t} X(G N P)_{t}$

Values of energy, GNP, and the energy/GNP ratio are listed in Table II-10 for the years $1975,1980,1985$, and 2000 .

Projections of energy consumption for industrial process heat in the TVA region are derived from national projections, adjusted by regional earnings in manufacturing [see Eqs. (II-12) amd (II-13)]. Demand for energy by industry in the U.S. is projected to increase at an annual rate of $2.6 \%$ over the reference years compared to $3.6 \%$ in the TVA region over the same time period. This regional variation in the demand for energy reflects the increasing proportion of earnings projected to originate in the region by the year 2000. Earnings in manufacturing is projected to increase at an annual rate of $3.1 \%$ in the U.S. compared to $3.9 \%$ in tha TVA region.

Petroleum consumed in the petroleum refining lindustry is creaced in the anlalysis as in-stream process losses during the distillation of crude oil into gasoline, distillate, and other fractions. In the analytical framework of the Reference Energy System, this energy is accounted for as an efficiency loss (7\%) shown at the refining and conversion of crude oil.

TRANSPORTATION SECTOR

Transportation accounts for approximately $25 \%$ of total U.S. energy consumption, varying regionally from 1 ess than $20 \%$ in the gulf states to over $30 \%$ on the west coast. In the area serviced by TVA transportation accounts for $23 \%$ of total energy consumption. The relatively low proportion of energy consumed by transportation in the gulf states region is primarily due to the high energy requirements for the extraction of petroleum and natural gas in this region. The disproportionately high quantity of energy consumed on the west coast is due to the heavy dependence on the automobile in California. Practically all energy demanded in the transportation sector is in the 
form of petroleum products with very minor amounts of electricity and natural gas. At pre-embargo fuel prices, energy consumption was expected to grow at a slightly higher rate than the demand for transportation services because of continued shifts to more energy intensive modes such as air: and truck. Higher fuel prices are not expected to significantly affect the overall demand for transportation services in this scenario but will stimulate significant energy savings through equipment improvements:in private ground transportation.

Automobile

In 1975 the automobile consumed 52\% of the energy in the transportation sector compared to $31 \%$ projected for 2000 , reflecting improved automobile fuel economy and market saturation. The total number of automobiles in the region is calculated as a function of the number of vehicles per driving age population in each state and the state population serviced by TVA. The number of vehicles per driving age population is derived from the total number of registrations ${ }^{1}$ in each state and the state's population 16 years of age and older. The number of vehicles per driving age population in the region was 0.61 in 1975 , the same as the national average. The number of registered vehicles has historically been an increasing proportion of the driving age population. This trend is not expected to continue as the market becomes saturated. It is projected that by the year $200085 \%$ of the population over 16 years of age will own automobiles. A constant value of 10,800 miles per vehicle is multiplied by the number of vehicles in calculating annual-vehicle-miles traveled (VMT). 10,800 miles is a national average from the FHWA, adjusted by the R. L. Polk data.

Automobile gasoline consumption is computed as a function of VMT's and the fleet average fuel economy. The fleet average fuel economy is derived for each reference year based on the mix of model years on the road, the distribution of vehicle-miles with age of auto, and the fuel efficiency per model year as follows:

COMPOSITE FUEL EFFICIENCY IN YEAR $t=$ [TOTAL VEHICLE-MILES/TOTAL FUEL REQUIREMENTS ${ }_{t}$ where, [TOTAL FUEL REQUIREMENTS $]_{t}=$ :

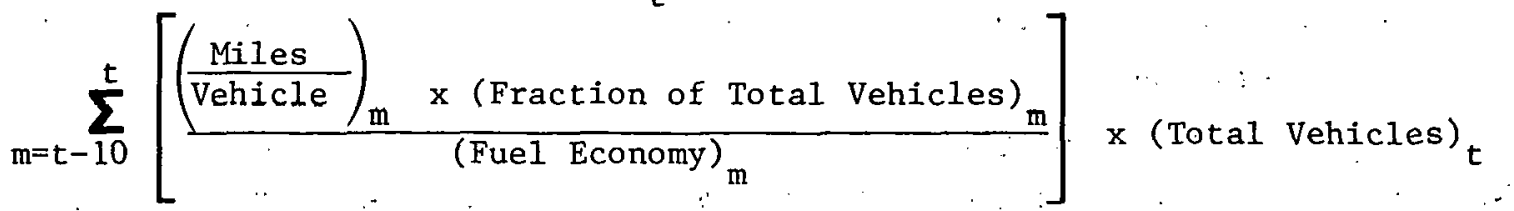

\footnotetext{
TThe R. L. Polk and Company estimate of registered vehicles is used rather than the Federal Highway Administration (FHWA) count. The FHWA count includes all. vehicles that were operated on the roads during the calendar year. The Polk estimates, considered more reliable, measures the number of vehicles operating at a fixed point in time reflecting re-registered and scrapped vehicles.
} 
m $=$ Model year

$t=$ Projection year--1980, 1985, 2000

The 1985 values of the variables in the above equation are given in Table II-11. Fuel requixements for 1980 and 2000 are computed in a similar manner. Fuel economy per model yeax is assumed to be $10 \%$ lower than specified in the Energy Policy and Conservation Act because of typically observed nonoptimum engine performance in older model vehicles.(20) The fleet average fuel economy projected for 1980 , 1985 and 2000 is $14.9 \mathrm{mpg}, 19.3 \mathrm{mpg}$, and $25 \mathrm{mpg}$, respectively.

Truck and Bus

The truck and bus category includes all gasoline and diesel fucl not consumed by automobiles; marine and aviation consumption of gasoline is included in ship and aix transport, respectively. Thus, gasoline and diesel fuel consumed by agricultural, construction, and miscellaneous equipment is included in the truck and bus category. Trucks are by far the largest energy consumer in this category, with buses using less than $5 \%$ of the fuel consumed.

Truck1ng activity is subdivided into two classes--freight trucking includes all trucks over 10,000 lbs gross vehicle weight (GVW) and nonfreight trucking includés all trucks under 10,000 lbs GVW. Freight trucking activity is measured in, terms of ton-miles and the fuel economy of these vehicles is measured in terms of Btu's per ton-mile. Estimates of ton-miles per truck, Btu's per ton-mile, and the fraction of gasoline versus diesel powered trucks are based on an FEA report on Trucking Activity and Fuel Consumption. (39) Nonfreight trucking activity is measured in terms of truck-miles and the fuel economy of these vehirles is measured in terms of Btu's per truck-mile. Estimates of miles per truck and the number of trucks by weight class are derived from Census of Transportation data. (44) The number of trucks in the TVA region is estimated from the total number of trucks in each state and the fraction of the population in that state which is serviced by TVA. Gasoline and diesel fuel consumption is then computed as a function of regiona1 trucking activity and the energy intensiveness of the trucks (see Tables T.T-12 and II-13). Passenger-miles for local, intercity and school buses are estimated in proportion to the pupulation.

Historically, freight trucking activity in the U.S. has increased in proportion to GNP, and this trend is projected to continue through the year 2000 with GNP gxowing at an annual rate of 3.2\%. Regional freight trucking activity in 1980 , 1985 and 2000 is then derived from the U.S. projections based on regional earnings. This methodology is analogous to that followed in the commercial sector. 
Table II-11

AUTOMOBILE FUEL ECONOMY - 1985

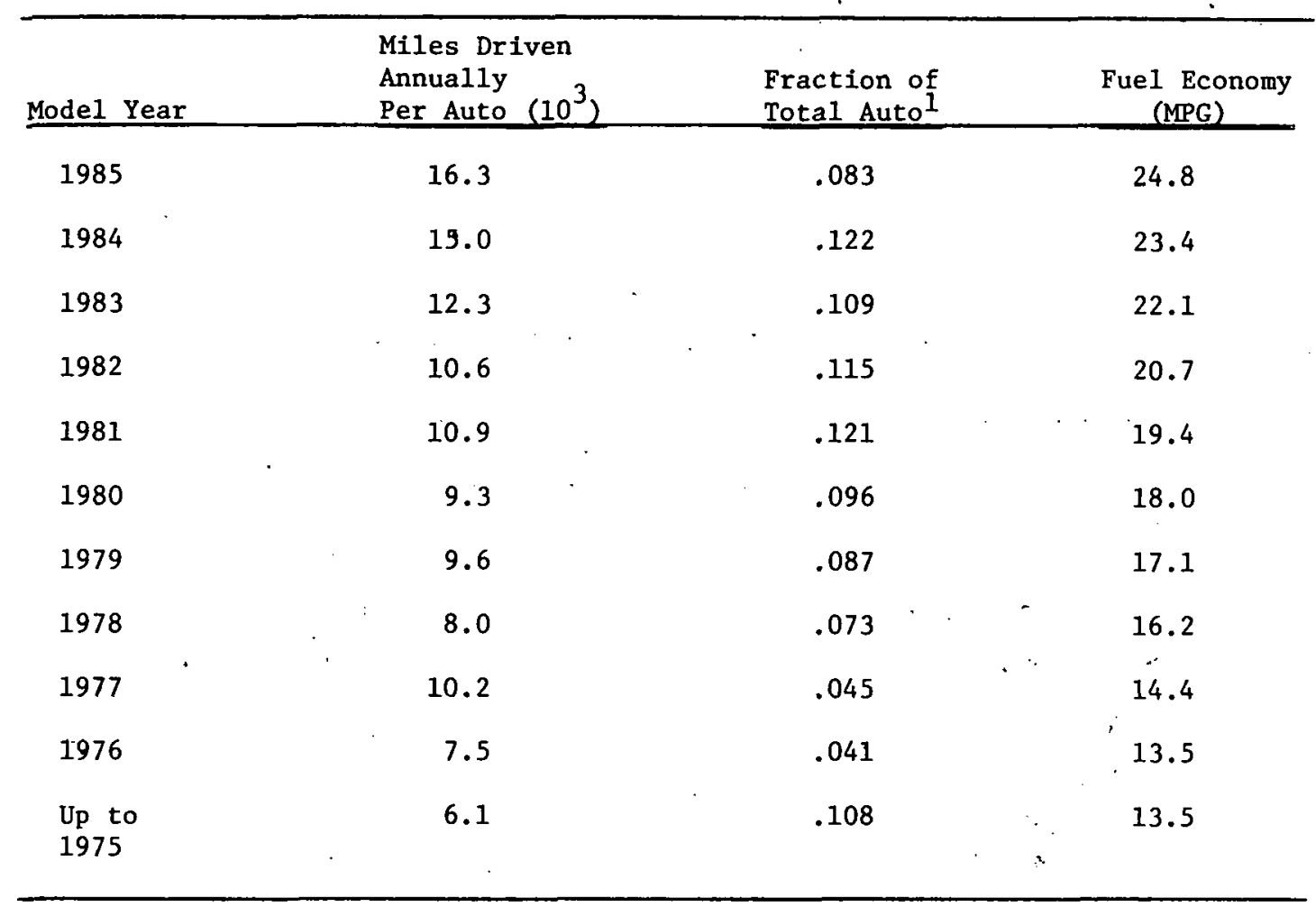

${ }^{1}$ Source: Referẹnce 19.

Table II-12

TVA MODAL TRANSPORTATION PROJECTIONS

(Billions)

\begin{tabular}{lcccc}
\hline & 1975 & 1980 & 1985 & 2000 \\
\hline $\begin{array}{l}\text { Passenger-Miles } \\
\text { Air }\end{array}$ & 2.2 & 3.4 & 4.7 & 10.7 \\
Local \& Intercity Bus & 1.4 & 1.9 & 2.2 & 3.9 \\
School Bus & 1.2 & 1.3 & 1.3 & 1.4 \\
Ton-Miles & & & & \\
A1r & - & - & - & - \\
Truck (GVW over & & & & \\
$\quad 10,000$ lbs.) & 16 & 20 & 25 & 45 \\
Ship & 25 & 29 & 33 & 47 \\
Rail & 26 & 30 & 34 & 48 \\
Truck-Miles & & & & \\
Non-freight Trucking & 9 & 12 & 16 & 31 \\
\hline
\end{tabular}


Table II- 13

ENERGY INTENSIVENESS BY TRANSPORT MODE

\begin{tabular}{lrrrr}
\hline & 1975 & 1980 & 1985 & 2000 \\
\hline $\begin{array}{l}\text { Btu/Passenger-Mile } \\
\text { Air. }\end{array}$ & 8698 & 7918 & 7431 & 7431 \\
Local \& Intercity Bus & 1490 & 1490 & 1490 & 1490 \\
School Bus & 1704 & 1704 & 1704 & 1704 \\
Btu/Ton-Mile & & & & \\
Air & - & - & - & - \\
Truck (GVw over & & & & \\
$\quad$ 10,000 1bs.) & 4678 & 4444 & 4210 & 3509 \\
Ship & 567 & 567 & 567 & 567 \\
Rail & 709 & 709 & 709 & 709 \\
Btu/Truck-Mile & 12061 & 11458 & 10855 & 9046 \\
Non-freight Trucking (mpg) & $(10.4)$ & $(10.9)$ & $(11.5)$ & $(13.8)$ \\
\hline
\end{tabular}


$\left(\begin{array}{c}\text { TVA TRANSPORT } \\ \text { ACTIVITY }\end{array}\right)_{t}=\frac{\left(\begin{array}{c}\text { U.S. TRANSPORT } \\ \text { ACTIVITY }\end{array}\right)_{t}}{\left(\begin{array}{c}\text { U.S. TRANSPORT } \\ \text { ACTIVITY }\end{array}\right)_{1975}} \times\left(\begin{array}{c}\text { EARNINGS } \\ \text { RATIO }\end{array}\right)_{t} \times\left(\begin{array}{c}\text { TVA TRANSPORT. } \\ \text { ACTIVITY }\end{array}\right)$ (II-20) where TRANSPORT ACTIVITY = Ton-miles for freight trucking, rail, or ship. Truck-miles for nonfreight trucking Passenger-miles for air transport. $t=$ Projection year--1980, 1985 and 2000 .

The Earnings Ratio is given in Eqs. (II-8) and (II-9) for the commercial sector where earnings in this sector is redefined to be total earnings from OBERS Projections of Regional Economic Activity.(17) Freight trucking activity in the TVA region is projected to increase at an annual rate of $4.2 \%$, from 16 billion ton-miles in 1975 to 45 billion ton-miles in the year 2000. Nonfreight trucking activity in the TVA region is projected to increase at an annual rate of $5.1 \%$, from 9 billion truckmiles in 1975 to 31 billion truck-miles in the year 2000. Projections of demand for gasoline and diesel fuel are based on a $25 \%$ improvement in the fuel economy of all trucks.: This efficiency improvement includes the fuel savings derived from the projected changeover to diesel engines. In $197523 \%$ of the motor fuels consumed by trucks and buses was in the form of diesel fuel compared to $69 \%$ projected for the year 2000 .

Air Transport

Consumption of jet fuel and aviation gasoline by both commercial air carriexs and general aviation is accounted for in this demand category. Demand for jet fuel and aviation gasoline in $1975^{\circ}$ was detexmined for the state of Tennessee from published data. $(10,48)$ Consumption of jet fuel and aviation gasoline in the TVA region, excluding Tennessee, was estimated from a survey of the commerical airports serving the area. Air passenger-miles were then derived from the estimated fuel consumed in the region in 1975, given an average energy intensity for air transportation in the U.S. of 8698 Btu's per passenger-mile. Projected energy consumption is computed from Air Transportation Association of America $(34,35)$ projections of U. S. domestic and international air passenger-miles, adjusted by regional eaxnings [see Eqs. (II-20), (II-8), and. (II-9)]. Air passenger miles in the TVA region are projected to increase from 2200 million passenger-miles in 1975 to 10,700 million passenger-miles in the year 2000, at an disual rate of $6.5 \%$. 
Railroads, Ships, and Pipelines

Consumption of diesel fuel by railroads is computed as a function of rail transport activity, measured in terms of ton-miles, and the energy intensiveness of the railroads, measured in terms of Btu's per ton-mile. Regional demand in each state is estimated for 1975 by assuming that the demand in a state is proportional to the fraction of its population serviced by TVA. Demand in the region is projected to increase in proportion to U.S. projections, adjusted by regional earnings [see Eqs. (II-20), (II-8), and (II-9)]. Rail freight ton-miles are projected to increase from 26 billion ton-miles in 1975 to 48 billion ton-miles in the year 2000 at an annual growth rate of $2.5 \%$.

Consumption of residual. ofl, distillate oil and gasoline by commercial shipping and recreational boating is accounted for in the water cranspusl caleguiy. Commercial shipping's demand for fuel oil in 1975 is computed from the demand for fuel oil by ships in the state of Tennessee, inflated by the population in the TVA region relative to the population in Tennessee. Kegional energy demands for commercial shipping are derived from Tennessee data only rather than from the energy usage in each state because of the disproportionate share of port facilities in the states of Alabama and Mississippi. Demand for fuel oil by the commercial shipping industry is projected to increase in proportion to U.S. projections, adjusted by regional earnings [see Fqs. (II-20), (II-8) and (II-9)]. Commercial shipping ton-miles are projected to increase from 25 billion ton-miles in 1975 to 47 billion ton-miles in the yeax 2000 at an annual growth rate of $2.5 \%$. Demand for gasoline by recreational boating in 1975 is estimated for each state in the region by assuning dewand is proportional to the state population serviced by TVA. Demand for gasoline by recreational boating is projected to increase at an annul growth rate of $4.6 \%$ through 1985 based on historical data, and is reduced to $3 \%$ thereafter.

Pipeline fuel represents some $6 \%$ of total industrial consumption of natural gas (including electric utilities) in the United States. Alchough use of natural gas as a pipeline fuel is concentrated in the producing states, almost one-thixd of the total amount is consumed at compressor stations located in the northeast and northcentral regions of the country. The use of natural gas to power pipeline pumping stations in the TVA region is escalated in proportion to the consumption of natural gas in the region. 
Historically the United States has been almost entirely dependent upon fossil fuels for its primary energy resources. With diminishing supplies of natural gas and oil this reliance is expected to decrease as new technologies such as nuclear, solar and geothermal are gradually introduced into the national energy system. The direct use of solar and geothermal energy for space heat and process heat and the use of these technologies to generate electricity is projected to supply less than $5 \%$ of the nation's energy requirement by the turn of the century, according to the President's National Energy Plan. Nuclear power is projected to play a major role in satisfying the nation's demand for electric power, meeting $41 \%$ of the load forecast for 2000 compared to $9 \%$ in 1975 . In the TVA region electricity generated from nuclear plants is projected to play an even greater role than in the nation as a whole, meeting $57 \%$ of the demand for electric power in 2000 .

Aside from nuclear, coal is the other energy resource expected to replace the diminishing supplies of oil and natural gas.. The U.S. Bureau of Mines estimates that 219 billion tons of coal are economically recoverable from a demonstrated coal reserve of twice that amount. (24) Demand for coal is expected to reach one billion tons in 1985 and two billion tons by 2000 compared to 640 million tons in 1975 . The origin of this coal, whether from underground mines in the east or new strip mines in the west, is an issue currently receiving national attention. Environmental regulations coupled with the anticipated emergence of new markets for coal (synthetic fuels) are rapidly changing the economics of coal use. Perhaps the most visible example of this has been the rapid increase in demand for western coal. The high cost of pollution control equipment, especially for sulfur removal, coupled with the tremendous jump in oil prices has brought on a boom in low sulfur western coal development. This boom is partly predicated on meeting the sulfur dioxide emissions levels contained in the New Source Performance Standards (NSPS) for the electric utility industry $\left(1.2 \mathrm{lbs} \mathrm{SO}_{2} / 10^{6} \mathrm{Btu}\right)$. Legislation was recently enacted requiring that the Best Available Control Technology (BACT): be installed on all new coal-fired power plants. The installation of flue gas desulfurization at all new coal-fired power plants, regardless. of the sulfur content of the coal, reduces the economic advantage of burning low sulfur coal. Uncertainties concerning 
the relative costs of scrubbing high and low sulfur coals make the impact of this legislation on eastern and western coal production difficult to assess at this time. In developing a projection of coal mining in the TVA region the results of the National Coal Assessment (28) study were applied in estimating production levels for 1980,1985 and 2000. It is assumed that coal production in the TVA region will increase at the same rate as forecast for the Intexior Appalachia region from the "Recent Trends" scenario in the National Coal Assessment. This results in a $3.5 \%$ growth rate from 1.975 to 1985 and a $1.8 \%$ growth rate thereafter and compares favorably with the projections for Appalachia contained in the National Energy Outlook. (25)

Coal production in the region was approximately 695 txillion Btu's in 1975 and was computed from county data published by the Bureau of Mines. (8) Production in a county is assumed to equal total production in that county as estimated by the Bureau of Mines if the entire county is within the TVA service territory. If the entixe county is not within the TVA service territory then coal production is assumed proportional to that fraction of land area in the county that is within the TVA service texritory. Land area is estimated from a map of the region showing county borders. $45 \%$ of the coal in the region is produced from underground mines and $55 \%$ from strip mines. Thus,

$$
\begin{aligned}
& {[\mathrm{COAL}]_{\mathrm{TVA}}=\sum_{\hat{i}}^{\text {COUNTY }}\left[(\mathrm{COAL})_{i} \mathrm{x}^{\mathrm{AREA}_{i}} \mathrm{TVA}_{i} / \mathrm{AREA}_{\mathbf{i}}\right]} \\
& \text { where, }(C U A L)_{i}=\text { Coal production in region } 1 . \\
& \text { AREA }_{i}=\text { Land area in county } i \text {. } \\
& \mathrm{AREA}_{\mathbf{i}} \text { TVA = Land area in county } i \text { that is serviced by TVA. } \\
& i=\text { Councies in TVA reglun. }
\end{aligned}
$$

Minimal quantities of oil and natural gas were produced in the TVA region in. 1975 and no substantial increase is projected over the reference years. Oil refinexy capacity in the region was 43,900 baxxels per day, producing approximately 75 trillion Btu's. of refined petroleum products in 1975. ELECTRIC UTILITY SECTOR

The Tennessee Valley Authority is a wholly owned corporation of the United States Government established by Act of Congress in 1933 to develop the Tennessee River System and to assist in the development of other resources in the Tennessee Valley. The production and sale of electric power are part of TVA's resource development program. . TVA supplies power at wholesale to 160 municipal and cooperative distributors which in turn distribute power to about 2.5 million residential, commercial and industrial customers. 
These customers are located in seven states including the entire state of Tennessee and parts of Alabama, Georgia, Kentucky, Mississippi, North Carolina and Virginia. TVA also serves directly 49 industrial customers with large or unusual power requirements and several Federal installations including uranium enrichment plants located at Oak Ridge, Tennessee and Paducah, Kentucky.

The Tennessee Valley Authority has traditionally depended upon hydroelectric power and coal to meet its power requirements. Electricity generated from nuclear plants is playing an increasing role in meeting the systems demand for base load electric power with gas turbines and pumped storage being used to meet the systems demand for peak power. Electricity generated from coal-steam plants met $72 \%$ of the demand for electric power in 1975, hydroelectric power satisfied $20 \%$ of demand, and electricity generated fröm nuclear plants and gas turbine peaking units met the remainder of the load in 1975. The generation mix shown in Table III-1 assumes interchange deliveries and receipts net to zero and that all, of the power sold by TVA is generated within the system. Actual net purchases and deliveries of electric power were a positive input to the system thus accounting for the slight difference between system generation data published by TVA(21) for:1975 and that appearing in Table III-1. Heat rates reported by TVA for 1975 were used to compute fossil and nuclear fuel requirements. Output from hyroelectric plants is converted to theoretical energy inputs (primaxy resources) based on the equivalent coal-steam electric heat rate of $9880 \mathrm{Btu}$ per $\mathrm{kWh}$ in 1975. Electricity sales totaled 318 trillion Btu's or 112 billion kilowatt-hours in 1975, remaining approximately constant since 1973. This trend is similar to that experienced by many other utilities across the nation since the Arab oil embargo and is attributed to both energy conservation and the depressed economic conditions that have existed in the U.S.

Recent electric utility forecasts of future energy requirements have been reduced from what they wexe in the 1972 to 1973 time period. Higher energy prices, depressed economic conditions, and the "conservation ethic" have all been contributing factors to the low energy growth recently experienced. These factors have added a considerable degree of uncertainty to future projections. Traditionally, utilities have depended upon historical trends in forecasting future loads, but this method is rapidly being replaced by more sophisticated techniques using econometrics and detailed engineering analyses of demands. A systems approach using the latter technique is being applied in this study to project requirements for electric power. More specifically, demand for electric power is obtained from the summation of electric demands in 1980, 1985, and 2000 over all other demand categories, adjusted to include transmission, distribution and pumped storage losses. 
Table III-1

TVA ELECTRIC GENERATION - BY CENTRAL STATION POWER PIAANT

\begin{tabular}{|c|c|c|c|c|c|}
\hline \multirow[b]{3}{*}{ Coa1-Steam } & \multicolumn{5}{|c|}{ Millions of KwH (Percent) } \\
\hline & \multicolumn{2}{|c|}{1975} & 1080 & 1005 & 2000 \\
\hline & $9,880 \mathrm{Btu} / \mathrm{kWh}$ & $\begin{array}{l}80,602 \\
(72 \%)\end{array}$ & $\begin{array}{l}94,679 \\
(58 \%)\end{array}$ & $\begin{array}{l}66,429 \\
(34 \%)\end{array}$ & $\begin{array}{l}110,827 \\
(35 \%)\end{array}$ \\
\hline Nuclear-Steam & $10,570 \mathrm{Btu} / \mathrm{kWh}$ & $\begin{array}{l}7,429 \\
(7 \%)\end{array}$ & $\begin{array}{l}46,562 \\
(29 \%)\end{array}$ & $\begin{array}{c}107,891 \\
(56 \%)\end{array}$ & $\begin{array}{l}176,360 \\
(561 / 2 \%)\end{array}$ \\
\hline Hydroelcctric & $9,880 \mathrm{Btu} / \mathrm{kJh}$ & $\begin{array}{l}22,950 \\
(20 \%)\end{array}$ & $\begin{array}{l}18,276 \\
(11 \%)\end{array}$ & $\begin{array}{l}18,276 \\
(9 \%)\end{array}$ & $\begin{array}{l}18,276 \\
(6 \%)\end{array}$ \\
\hline $\begin{array}{l}\text { Oil-fired Gas } \\
\text { Turbine }\end{array}$ & $12,950 \mathrm{Btu} / \mathrm{kWh}$ & $\begin{array}{l}551 \\
(1 \%)\end{array}$ & $\begin{array}{l}2,393 \\
(1 \%)\end{array}$ & $\begin{array}{l}1,195 \\
(1 / 2 \%)\end{array}$ & $\begin{array}{l}1,846 \\
(1 / 2 \%)\end{array}$ \\
\hline Pumped Storage & - & - & $\begin{array}{l}1,347 \\
(1 \%)\end{array}$ & $\begin{array}{l}1,209 \\
(1 . / 2 \%)\end{array}$ & ${ }_{(2 \%)}^{5,948}$ \\
\hline Total & - & 111,532 & 163,657 & 195,000 & 313,257 \\
\hline
\end{tabular}


System generating capacity in service, under construction or planned as of June 30,1976 is shown in Table III-2 for the Tennessee Valley Authority. The mix of capacily additions projected by IVA results in a generation mix for 1985 of $34 \%$ coal-steam, and $56 \%$ nuclear-steam, with the remainder of the load being met by hydro, pumped storage and gas turbine peaking units. No capacity additions to hydropower are planned after 1980 and the electricity generated from hydro is projected to decrease from 22950 million kilowatt-hours in 1975 to 18276 million kilowatt-hours in 1980 and then remain constant at that level through the year 2000 . Pumped storage is projected to play an increasing role in meeting the systems demand for peak power with four units totaling $1530 \mathrm{Mw}$ expected to be operational by the end of 1978 and 5430Mw projected to be on line by the year 2000 . No additional gas turbine peaking units are planned after 1980. Coal continues to be an important fuel in meeting TVA's energy requirements, although nuclear power dominates the schedule of planned additions over the next ten years as illustrated in Figure III-1.

Projections of the basic energy demand for electricity over the reference years are obtained from the summation of electric demands in all other demand categories adjusted to include transmission, distribution, and pumped storage losses. Differences in the projected demand for electricity between TVA and BNL are less than $5 \%$ in 1980 and 1985 and $12 \%$ in 2000. These discrepancies are not unreasonable in view of the inherent uncertainties and dissimilar techniques used to develop the projections. Differences in the demand for electricity are primarily attributable to the residential sector and can be explained, in part, by differences in the assumed market penetration of appliances and projected use of electricity for domestic hot water heating. The generation mix for 1980, 1985 and 2000 was derived from the TVA forecast after taking into account these reductions in demand. In 1985 Lhese demand reductions are equivalent to one less nuclear power plant of approximately 1250 megawatts capacity. Considering the lengthy delays in construction recently encountered across the nation and the ambitious construction program underway in the region, the reduced demand for electricity projected in this study should not cause excessive base load capacity in 1985. In 2000 the projected demand reductions relative to the TVA forecast are equivalent to four fewer nuclear plants ( $5000 \mathrm{MW}$ ) and $1000 \mathrm{Mw}$ less coal capacity. If the BNL load forecast is realized in 2000 it would require some readjustment in planning, but should pose no problem if rescheduling is considered within a reasonable time frame. 


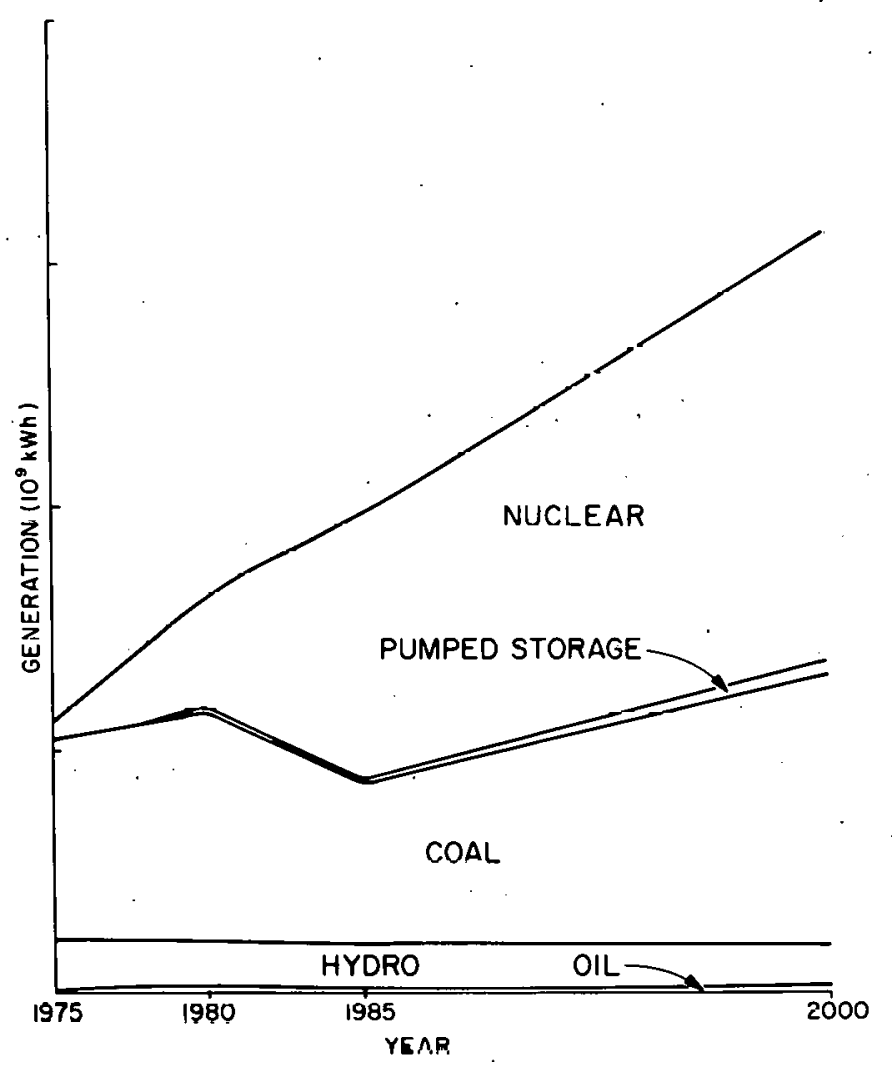

Figure III-1. Projécted electric generation in the TVA region. 
GENERATING CAPACITY ON JUNE 30, 1976

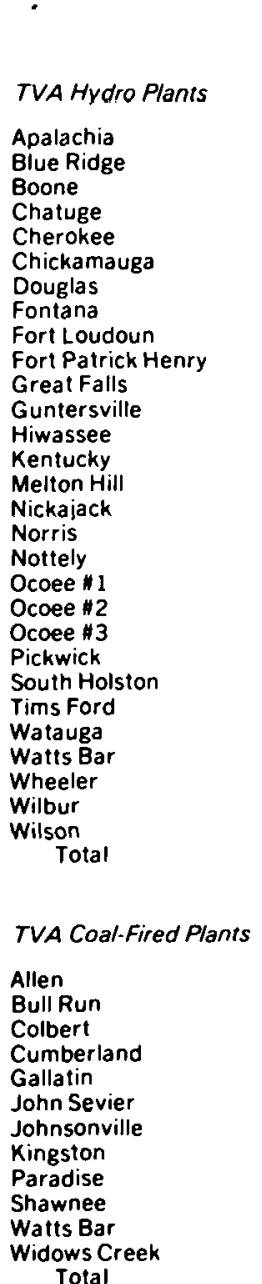

TVA Nuclear Plants

Browns Ferry
In Service

\begin{tabular}{|c|c|}
\hline $\begin{array}{l}\text { No. } \\
\text { Units }\end{array}$ & $\begin{array}{c}\text { Installed } \\
\text { Capacity }-k \mathrm{~W}\end{array}$ \\
\hline 2 & 78,900 \\
\hline 1 & 20.000 \\
\hline 3 & 75,000 \\
\hline 1 & 10,000 \\
\hline 4 & 129.300 \\
\hline 4 & 111.000 \\
\hline 4 & 115.000 \\
\hline 3 & 238.500 \\
\hline 4 & 135.590 \\
\hline 2 & 36,000 \\
\hline 2 & 31,860 \\
\hline 4 & 101.700 \\
\hline 2 & 117.100 \\
\hline 5 & 175,000 \\
\hline 2 & 72,000 \\
\hline 4 & 100.350 \\
\hline 2 & 100.800 \\
\hline 1 & 15.000 \\
\hline 5 & 18,000 \\
\hline 2 & 21.000 \\
\hline 1 & 28.800 \\
\hline 6 & 220.040 \\
\hline 1 & 35,000 \\
\hline 1 & 45.000 \\
\hline 2 & 50,000 \\
\hline 5 & 153,300 \\
\hline 11 & 356.400 \\
\hline 4 & 10,700 \\
\hline 21 & 629,840 \\
\hline$\overline{109}$ & $\overline{3,231,180}$ \\
\hline
\end{tabular}

TVA Combustion

No. Installed

Units Capacily-kW

Allen

Colbert

Gallatin

Johnsonville

$$
\text { Total }
$$
$20 \quad 620,800$
476.000
$\begin{array}{r}325.200 \\ 1,088.000 \\ \hline\end{array}$
423.715
853,000
$27.071,480$
.

Alcoa Dams (12)

Corps of Engineers Dams (8)

Total System in Service

Under Construction or Planned

Browns Ferry Nuclear Unit 3

$1 \quad 1.152 .000$

Scheduled Commerical Operation-1977

Sequoyah Nuclear

$2 \quad 2.441 .160$

Scheduled Commercial

Operation-1978-1979

Raccoon Mountain Pumped Storage

Scheduled Commercial

Operation-1978

Watts Bar Nuclear

Scheduled Commercial

Operation-1979.1980

Bellefonte Nuclear

Scheduled Commercial

Operation-1980-1981

990,000

950.000

1.396 .500

$2,600,000$

$1,255,200$

846.500

1.485 .200

$1.700,000$

$1.700,000$
2.558 .200

2.558 .200
1.750 .000

240.000

1.977 .985

$\frac{1.977 .985}{17.749 .585}$

Proposed Hartsville Nuclear

Scheduled Commercial

Operation-1983.1984

Proposed Phipps Bend Nuclear

Scheduled Commercial

Operation-1984.1985

Proposed Yellow Creek Nuclear

Scheduled Commercial

Operation-1985-1986

$4 \quad 1.530 .000$

$2,539.800$

$2 \quad 2.664 .000$

$45,148,000$

$2.574,000$

$2 \quad 2.678 .000$

$19 \quad 20.726 .960$

$2 \quad 2,304,000$

Source: 1976 Power Annual. Report, Tennessee Valley Authority (21) 
IV. TVA REFERENCE ENERGY SYSTEMS

Reference Energy Systems for the TVA region defined for the years 1975, 1980, 1985, and 2000 are exhibited in a series of energy flow diagrams, Figures IV-l through, IV-4. These reference systems provide a compact framework for the representation of the entire energy system including resuurce extraction, refinement, conversion, transportation, and utilization. In the residential and commercial sectors the flow diagrams are function oriented (e.g., the heating of a certain number of homes), while in the industrial and resource sectors the RES's are process oriented (e.g., the electrolysis of alumina or mining of coal). Thus, these network representations of regional energy flows incorporate the major features of the energy system through individual activities or processes to provide a framework for assessing new technologies or policies.

The values on the left-hand side of the diagrams under the heading EXTRACTION represent resources into the system. The values on the right-hand side under the heading DEMAND CATEGORY represent basic energy demands in terms of a disaggregated set of end uses. The energy flowing through each stage of the RES is shown above the line representing the activity. In the demand categories, the numbers in parentheses represent the relative effectiveness or efficiency of the processes as described in Section II. On the supply side, these efficiencies represent losses from electrical conversion and transmission, petroleum refining, gas processing and distribution, and coal cleaning.

The Evaluation of New Technologies

In the remainder of this section, the manner in which the Reference Energy System can be applied to technology assessments will be briefly outlined. The regional variability of the energy system and the diversity of technologies being considered make a formal methodology for assessments inappropriate. More preferable are the basic ground rules presented here.

Underlying all evaluations is the Reference Energy System and associated data as they provide a baseline against which new technologies can be measured. The place of a new technology should be noted on the perturbed Reference Energy System for the time frame of interest. The impact of the Hew lechnology in terms of resource consumption may be evaluated by modifying the energy flow paths to incorporate the new technology. Alternative paths thruugh the network reflect the 
substitutability of resources and technologies for one another. A choice is necessary among the technologies to be replaced, and each choice will be determined by the purpose of the assessment and the energy priorities at the time the analysis is performed. In many cases it is convenient to represent a resource change in terms of imported oil since this measure will be of obvious importance. in the foreseeable future.

In the case of space heating, the quantity. of electricity required to allow for the introduction of heat pumps into a given fraction of the homes presently heated by natural gas may be computed by accounting for differences in efficiencies beween the two technologies. Any savings in primary resources brought about by this technology shift from gas to heat pumps can be computed by following the network flow back to the left-hand side of the diagram, acrounting for additional fuels required as input to electric generation. The amount of electricity required for air conditioning displayed in the RES under the heading UTILIZING DEVICE may be computed in terms of primary resource requiremente for air conditioning by moving from right to left in the network, allowing for efficiencies encountered including losses incurred in the generation of electric power. The following is a partial list of parameters to be considered in a technology assessment:(27)

- Implementation dates

- Degree of implementation (fraction of demand satisfied by the new technology)

- Regional limitations (e.g., solar heating and couling would have considerable regional variation)

- Primary input fuel.

- Economic data.

-- Capital cost

-- Operating and maintenance cost

-- Fuel cost

-- F1xed charge rate (e.g., 15\%). This includes the cost of money, depreciation, taxes, and insurance.

For systems that may not: be competitive in terms of dollar cost but that have significant environmental or conservation benefits, the analysis should emphasize the cost of achieving those benefits.

Allowances for moderate conservation are either explicitly or implicitly in- . corporated in the energy systems in appropilate deuland categoriee where the technology currently exists. These reductions in per capita energy demand are brought 
about either through regulation or price-induced cutbacks in energy consumption. Improvements in fuel economy for automobiles as mandated by law are taken into account in projecting gasoline consumption, for example. Conservation in industry is reflected as a reduced growth rate for industrial process heat. Again, it should be emphasized that the Reference Energy Systems in this report are base case scenarios representing reasonable energy use patterns and are not meant to reflect either a forecast based entirely on historical growth rates or a projection allowing for the introduction of new technologies and strong conservation measures.

As a numerical example of the perturbation analysis discussed, the impacts of a conservation strategy applied to petroleum consumption in the industrial sector will be evaluated. It is assumed that by the year 1985 oil to industrial process heat will be reduced by $15 \%$ per unit of output. This reduction is applied to the level of crude oil imports to the region in. 1985. The oil to industrial process heat with no conservation, as shown in Table IV-1, is from the 1985 Reference Energy System (Figure IV-3). The oil savings is computed by reducing oil input to industrial process heat by $15 \%$ and dividing this result by the refining efficiency, 0.93 . Thus a $15 \%$ reduction in: oil requirements to industrial process heat reduces crude imports to the region by $9.4 \mathrm{x}$ $10^{12} \mathrm{Btu}$ (equivalent to about $2440 \mathrm{bbl/day}$ ). The cost savings are calculated by . assuming that the price of oil in 1985 will be $\$ 14.50 / \mathrm{bbl}$ or $\$ 2.50$ per million Btu. Then the dollar savings is

$9.4 \times 10^{12}$ Btu $\times \$ 2.50 / 10^{6}$ Btu $=\$ 23.5$ million

Table IV-1

IMPACT OF INDUSTRIAL OIL CONSERVATION, 1985

\begin{tabular}{lccc}
\hline & $\begin{array}{l}\text { Oil to Process Heat } \\
\text { With No Conservation }\end{array}$ & Oil Savings & $\begin{array}{l}\text { Oil to Process Heat With } \\
\text { Conservation }\end{array}$ \\
\hline TVA & 58.0 & 9.4 & 48.6
\end{tabular}




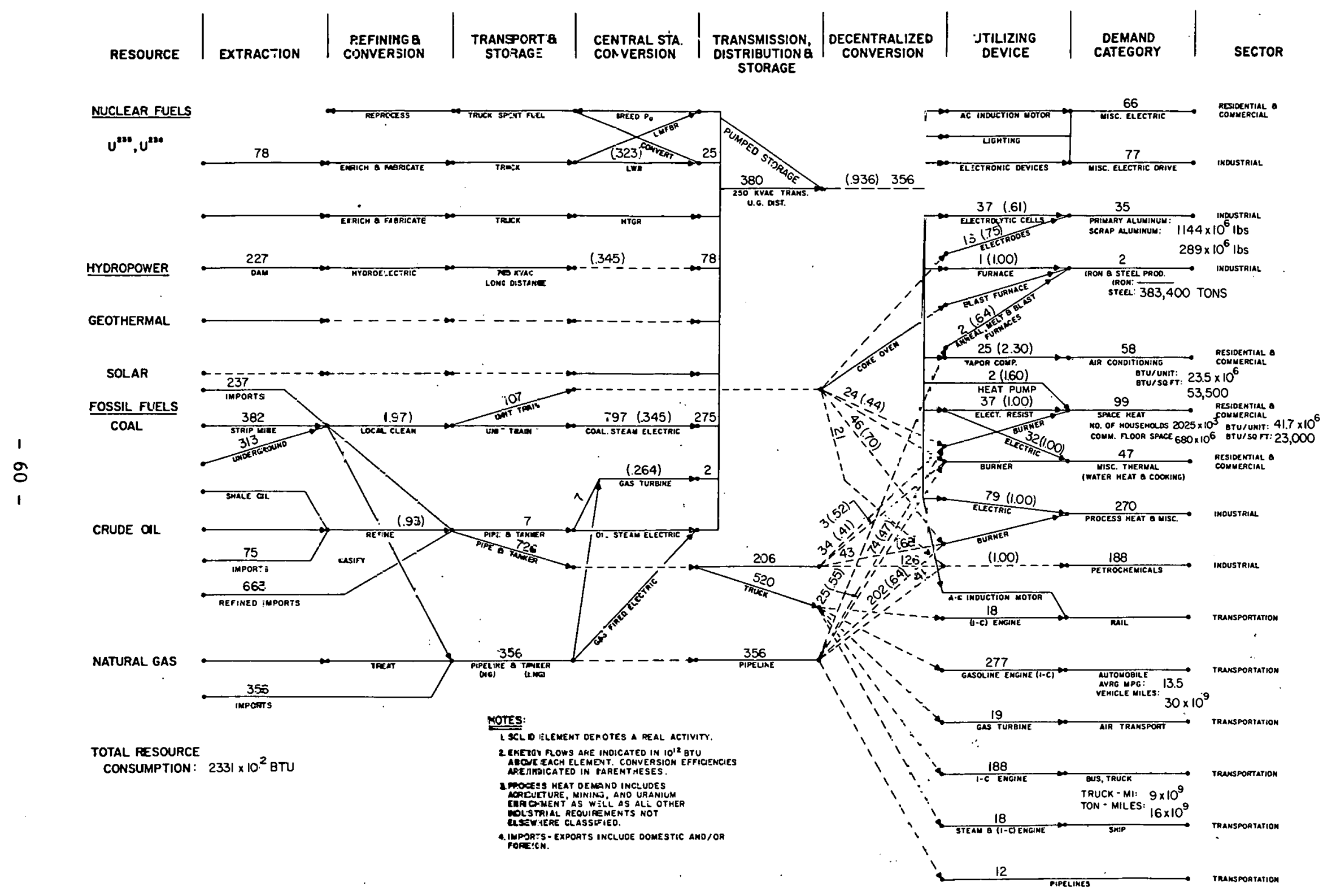

F1gu:e IV-1. TVA reference energy system, year $₫ 975$. 


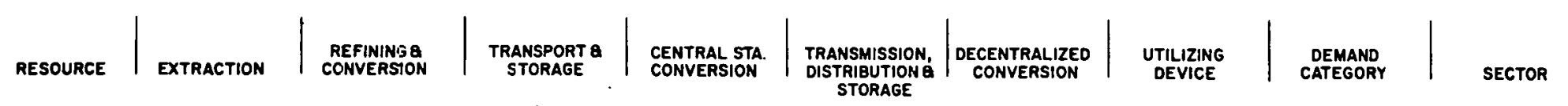

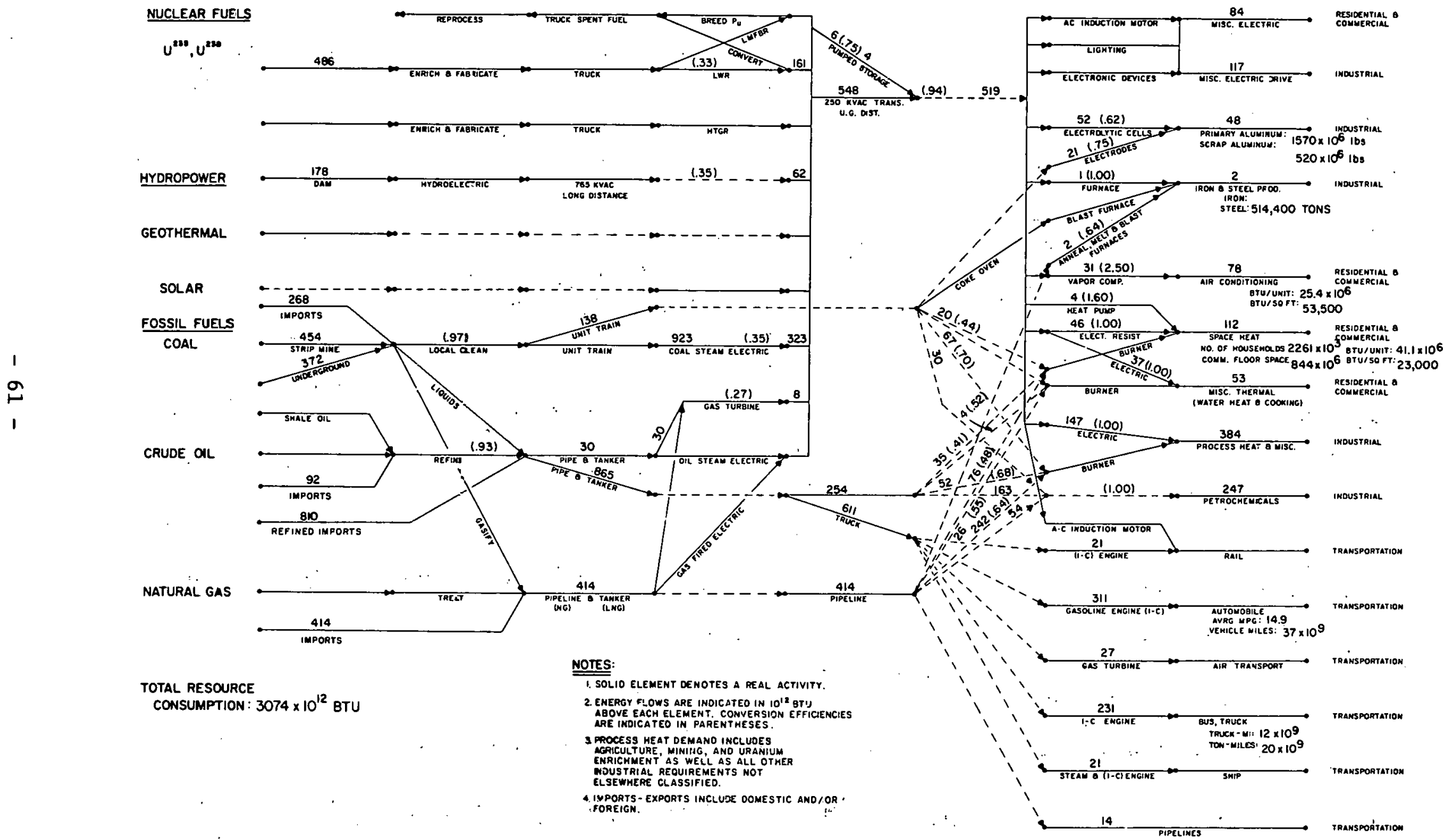

F1gure IV-2. TVA reference energy system, year 1980. 


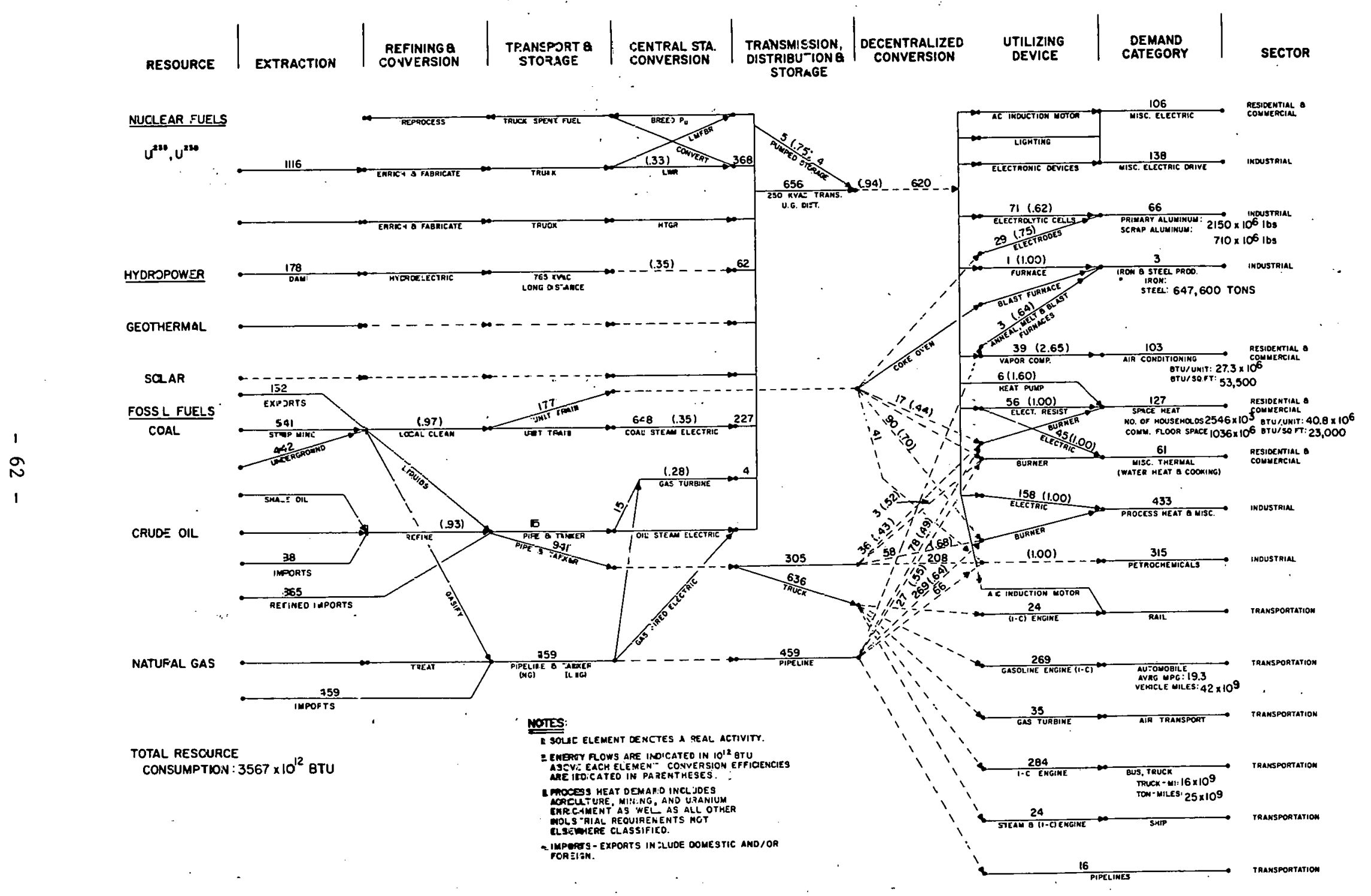

Figure IV-3. TVA reference energy system, year 1985. 


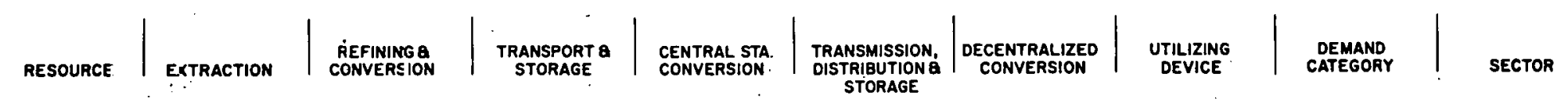

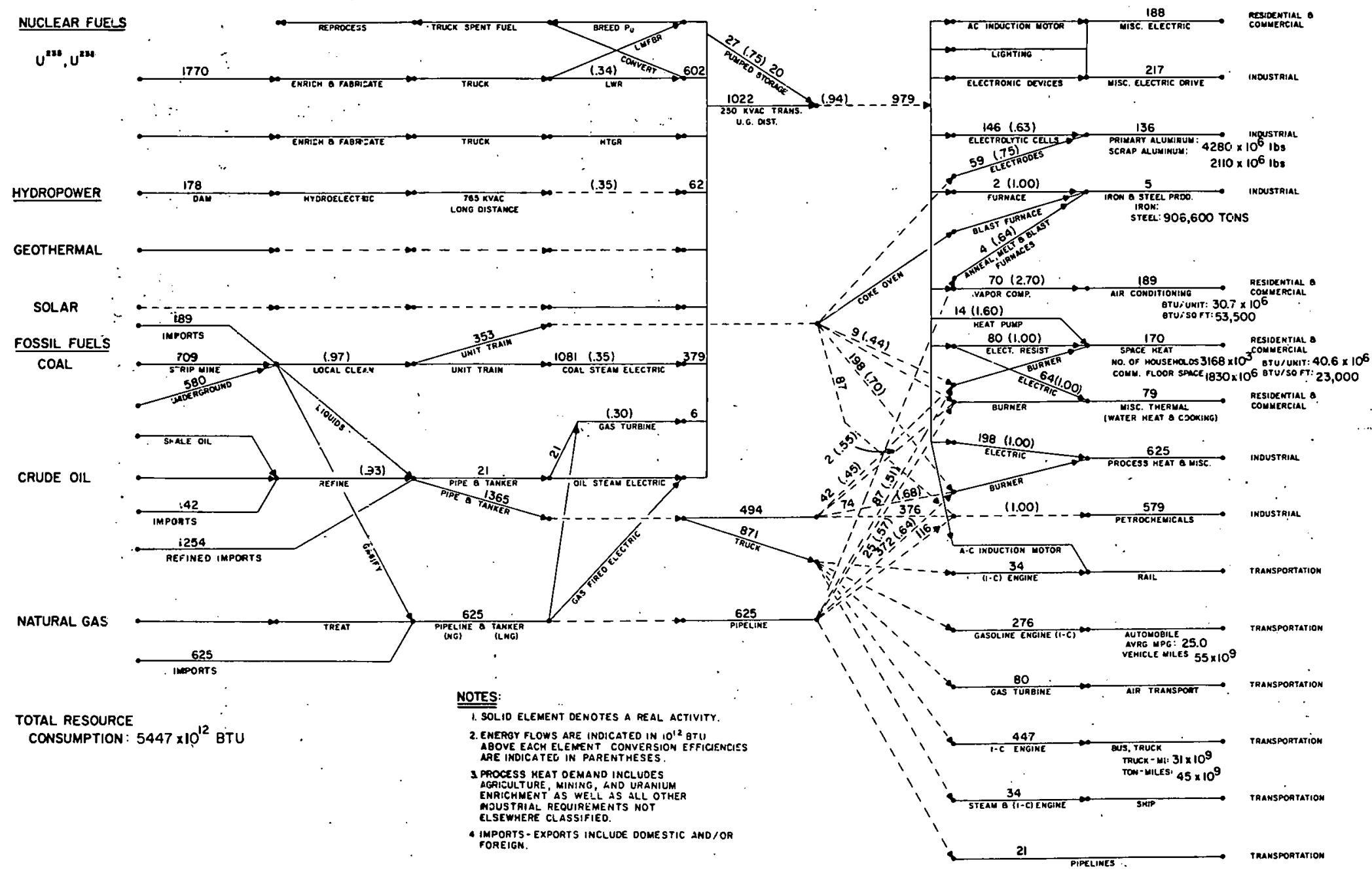

Figure IV-4. TVA reference energy system, year 2000. 


\section{REFERENCES}

1. Project Independence Task Force Report, Residential and Commercial Energy Use Patterns 1970-1990, Federal Energy Administration, Washington, D.C., November 1974.

2. Bureau of the Census, Census of Housing: 1970, Vol. 1--Housing Characteristics for States, Cities and Counties, Part 1--United States Summary, U.S. Department of Commerce, Washington, D.C., 1972.

3. Tansil, J., Residential Consumption of Electricity, 1950-1970, Oak Ridge National Laboratory, July 1973.

4. Bureau of Mines, Information Circular: Fuel and Energy Data, U.S. By States and Regions 1972, IC 8647, U.S. Department of Interior, Washington, D.C., 1974 .

5. Bureau of the Census, Statistical Abstracts of the U.S., 19/4, U.S. Vepartineil uf Commorce, Washingtnn, D.C., 1974 .

6. Stanford Research Institute, Patterns of Energy Consumption in the U.S., Washington, D.C., January 1972.

7. Associated Universities, Inc., Energy Modc1 Data Base, 1974, Brookhaven National Laboratory, Upton, N.Y.

8. Bureau of Mines, Minerals Yearbook 1974, Vol. I, U.S. Department of Interior, Washington, D.C., 1976 .

9. Bureau of the Census, Census of Manufacturers, 1972--Fuels and Electric Energy Consumed, U.S. Department of Commerce, Washington, D.C., 1973.

10. Federal Highway Administration, Highway Statistics 1975, Section I, U.S. Department of Transportation, Washington, D.C.

11. Bureau of Mines, Mineral Industry Surveys--Fuel 0il Sales, 1975, U.S. Department of Interior, Washington, D.C.

12. Edison Electric Institute, Statistical Yearbook of the Electric Utility Industry For 1975, New York, N.Y., October 1976.

13. Economic Research Service, U.S. Department of Agriculture, Encrgy and U,S. Agriculture: 1974 Data Base, Volume 2: Commodity Series of Energy Tables, developed in cooperation with the Federal Energy Administration, Washing cun, D.C., April $1 y / 1$.

14. American Gas Association, Gas Facts, 1972, Arlington, Virginia, 1973.

15. Arthur D. Little, Inc., Implications of Natural Gas Consumption Pattern for the. Implementation of End-Use Priority Programs, Report to the. Office of the General Council, General Motors Corportation, Cambridge, Massachusetts. 
16. Bureau of the Census, Census of Housing: 1970, Structural Characteristics of the Housing Inventory, U.S. Department of Commerce, Washington, D.C., 1973.

17. U.S. Departments of Commerce and Agriculture, OBERS Projections--1972 Regional Economic Activity in the U.S., Series E, Vol. 4 - States, U.S. Water Resources Council, Washington, D.C., April 1974.

18. The Conference Board, Energy Consumption in Manufacturing, A Report to the Energy Policy Project of the Ford Foundation, Cambridge, Massachusetts, 1974.

19. Ford Foundation, Energy Policy Project, A Time to Choose, Cambridge, Massachusetts, 1974.

20. Ninety-Fourth Congress, First Session, Energy Policy and Conservation Act, Conference Report No. 94-516, Washington, D.C., December 8, 1975.

21. Tennessee Valley Authority, 1976 Power Annual Report, Knoxville, Tennessee, 1976.

22. Personal Communication with Energy Research, Tennessee Valley Authority, Chat tanooga, Tennessee.

23. Data provided by the Tennessee Valley Authority, Chattanooga, Tennessee.

24. Gunwaldsen, D., Bhagat, N., Beller, M., A Study of Potential Coal Utilization 1985-2000, Brookhaven National Laboratory, BNL 50771, Upton, New York, December 1977.

25. Federal Energy Administration, National Energy Outlook, Washington, D.C., February 1976.

26. "26th Annual Electrical-Industry Forecast," Electrical World, Vol. 184, No. 6., September 15, 1975.

27. Associated Universities, Inc., Sourcebook for Energy Assessment, Brookhaven National Laboratory, BNL-50483, Upton, New York, December 1975.

28. Krohm, Gregory, et al., Candidate Scenarios for the National Coal Assessment, preliminary draft, under contract to the Administrator for Environment and Safety ERDA, September 1, 1976.

29. Institute for Energy Analysis, The IEA Energy Simulation Mode1--A Framework for Long-Range U.S. Energy Analysis, ORAIJ-125, Oak Ridge, Asociated Universities, Oak Ridge, Tennessee, January 1976.

30. Hermelee, A. L., Regional Reference Energy Systems, prepared by Brookhaven National Laboratory for the Electric Power Research Institute, EPRI EA-462, Palo Alto, California, June 1977.

31. Lee, J., Energy Supply and Demand in the Northeast United States, BNL-20427, Brookhaven National Laboratory, Uptun, New Yurk, September, 1975. 
32. Bureau of Mines, Information Circular: Historical Fuels and Energy Consumption Data, 1960-1972--United States by States and Census Districts East of the Mississippi, IC 8704, U.S. Department of Interior, Washington, D.C., 1976.

33. Bureau of Mines, Information Circular: Historical Fuels and Energy Consumption Data, 1960-1972--United States by States and Census Districts West of the Mississippi, IC 8705, Department of Interior, Washington, D.C., 1976.

34. Air Transport Association of America, Domestic Industry Passenger Demand Forecast, 1974-2000--Trunk and Regional Carriers, Executive Summary, June 1975.

35. Air Transport Association of America, International Air Travel, Industry Passenger Demand Forecast, United States--Related Traffic, 1976-2000, Executive Summary, May 1976.

36. Allentuck, J., et al., Some Aspects of the Future Energy Demand-Supply Situation in New York State. BNL-21540, Brookhaven National T,abnratory, Upton, Now York, April 1976.

37. American Iron and Steel Institute, Annual Statistical Report 1974, Washington, D.C., 1975.

38. Bureau of the Census, Census of Mineral Industries: 1972, Area Series, East South Central States, U.S. Department of Commerce, Washingtnn, n.r., 1975,

39. Jack Faucett Associates, Trucking Activity and Fuel Consumption-1973, 1980, 1985, and 2000, prepared for the Federal Energy Administration, Washington, D.C., July 1976 .

40. Behling, David, J., Analysis of Past and Expected Future Trends in U.S. Energy Consumption, 1947-2000, BNL-50725, Brookhaven National Laboratory, Upton, New York February 1977.

41. Pilati, D. A., Room Air-Conditioner Lifetime Cost Considerations: Annual Operating Hours and Efficiencies, Oak Ridge National Laboratory, October 1975.

42. Bureau of the Census, Annual Housing Survey: 1975, United States and Regions, General Housing Characteristics--Part A, U.S. Department of Commerce, Washington, D.C., April 1977.

43. Jack Faucett Associates, Update to the National Energy Accounts: Energy Flows in the U.S., 1973 and 1974, Volumes I-VII, Submitted to the Federa1 Energy

Administration, Washington, D.C., September 1977.

44. Bureau of the Census, Census of Transportation: 1972, Vol. II-Truck Inventory and Use Survey, U.S. Department of Commerce, Washington, D.C., 1974.

45. Central Intelligence Agency, Free World Oil Refineries, Washington, D.C., December 1975. 
46. Federal Power Commission, Typical Electric Bills 1975, Washington, D.C., 1975.

47. American Society of Heating, Refrigeration and Air Conditioning Engineers, ASHRAE Guide and Data Book, P. 514, 1969.

48. Bureau of Mines, "News Release--Annual U.S. Energy Use Up in 1976", Department of The Interior, Washington, D.C., March 14, 1977. 


\section{APPENDIX A \\ SUMMARY OF ENERGY DEMAND AND FUEL MIX}

Projections of energy demand and fuel mix are summarized in Tables A-1 through A-4 for the Tennessee Valley Authority for the years 1975, 1980, 1985, and 2000. In the tables, the electricity delivered to each end use is indicated and the resources to generate electrical energy are tabulated in the row entitled "Electric Utility." Losses incurred in the extraction of resources are accounted for in the rows entitled "Methane Production," "Coal Production;" and "Refinery Use." 
Table A-1

Summary of Energy Demand and Fuel M1x, 1975

Region: Tennessee Valley Authority

\begin{tabular}{|c|c|c|c|c|c|c|c|c|}
\hline - & Methane & oil & $\begin{array}{l}\text { Coal \& } \\
\text { Wood }\end{array}$ & $\underline{\text { LPG }}$ & Nuclear & Bydro & Electric & $\begin{array}{c}\text { Total } \\
\text { Direct Use }\end{array}$ \\
\hline \multicolumn{9}{|l|}{ RESIDENTIAL : } \\
\hline Space Heat & 57.94 & 10.64 & 21.45 & 17.38 & & & 35.53 & 142.94 \\
\hline Water Heat & 15.94 & & & 2.12 & & & 24.10 & 42.16 \\
\hline Air Cond. & & & & & & & 14.61 & 14.61 \\
\hline cooking & 3.27 & & .36 & .77 & & & 6.08 & 10.48 \\
\hline Appl. \& Light & 2.14 & & & & & & 28.07 & 30.21 \\
\hline SUBTOTAL & 79.29 & 10.64 & 21.81 & 20.27 & & & 108.39 & 240.40 \\
\hline COMMERCIAL : & & & & & & & . & \\
\hline Space Heat & 15.92 & 3.25 & 2.84 & 2.28 & & & 3.83 & 28.12 \\
\hline Water Heat & 1.32 & .30 & & .13 & & & 1.04 & 2.79 \\
\hline cooking & 2.63 & & & & & & .36 & 2.99 \\
\hline Air cond. & & & & & & & 10.48 & 10.48 \\
\hline Mis. Electric & & & & & & & 32.98 & 32.98 \\
\hline Outdoor Lighting & & & & & & & 2.96 & 2.96 \\
\hline SIBBTOTAL & 19.87 & 3.55 & 2.84 & 2.41 & & & 51.65 & 80.32 \\
\hline \multicolumn{9}{|l|}{ INDUSTRIAL : } \\
\hline Aluminum & 7.32 & & 15.62 & & & & 37.06 & 60.00 \\
\hline \multicolumn{9}{|l|}{ Iron } \\
\hline Steel & 1.68 & & & & & & .88 & 2.56 \\
\hline Process Heat & 183.91 & 34.37 & 44.75 & & & & & 263.03 \\
\hline Electric Drive & & & & & & . & 77.11 & 77.11 \\
\hline Feedatocka & 41.27 & 125.69 & 20.64 & & & & -- & 187.00 \\
\hline Uranium Enrich. & . & & & & & & 74.54 & 74.54 \\
\hline SUBTOTAL & 234.18 & 160.06 & 81.01 & & & & 189.59 & 664.84 \\
\hline TRANSPORTATION & & & & & & & & . \\
\hline Automobile & & 277.07 & & & & . & & 277.07 \\
\hline Truck \& Bus & & 187.52 & & & & & & 187.52 \\
\hline Rail \& Transit & & 18.36 & & & & . & & 18.36 \\
\hline Air & & 19.14 & & & & & & 19.14 \\
\hline Pipelines & 12.13 & & & & & & & 12.13 \\
\hline Ship & & 17.57 & & & & . & & 17.57 \\
\hline SUBTOTAL & 12.13 & 519.66 & & & & $:$ & & 531.79 \\
\hline ELEC. UTILITY & & 7.12 & 797.33 & & 78.49 & 227.03 & $(354.20)$ & $755.77^{c}$ \\
\hline \multicolumn{9}{|l|}{ Methane Prod. } \\
\hline coal Prod. & & & 27.96 & & & & & 27.96 \\
\hline Refinery Use & & 5.25 & & & & & . & 5.25 \\
\hline Agriculture & 3.54 & .91 & .02 & 2.99 & & & 2.31 & บ. 11 \\
\hline Mining & 7.66 & 5.01 & 1.07 & & & & 2.26 & 16.00 \\
\hline TOTAL RESOURCES & & & & . & & & & \\
\hline CONSUMED & 356.67 & 712.20 & 932.04 & 25.67 & 78.49 & 227.03 & & 2332.10 \\
\hline
\end{tabular}

aydroelectric output is converted to theoretical energy inputs based on the equivalent coal-steam electric heat rate.

${ }^{b}$ Gives energy consumed as electricity at 3412.8 Btu/KWH. For fuels consumed in producing electricity see row labeled "Electric Utility."

"Taken as total resources consumed by utilities less plertricity deliverod to crd uoc. 
Table A-2

Summary of Energy Demand and Fuel Mix, 1980

Region: Tennessee Valley Authority

\begin{tabular}{|c|c|c|c|c|c|c|c|c|}
\hline$\underline{1}$ & Methane & $\underline{0 i 1}$ & $\begin{array}{l}\text { Coal \& } \\
\text { Wood }\end{array}$ & $\underline{\text { LPG }}$ & Nuclear & Hydro ${ }^{a}$ & Electric & $\begin{array}{c}\text { Total } \\
\text { Direct Use }\end{array}$ \\
\hline RESIDENTIAL : & & & & & & & & $\therefore$ \\
\hline Space Heat & 58.94 & 9.22 & 17.03 & 19.22 & & & 43.52 & 147.93 \\
\hline Water Heat & 16.37 & & & 2.37 & & & 28.21 & .46 .95 \\
\hline Air Cond. & . & & & & & & 16.45 & 16.45 \\
\hline cooking & 3.01 & & .20 & .65 & & & 7.23 & 11.09 \\
\hline Appl. \& Light &.$\quad 2.19$ & & & & & & 34.57 & 36.76 \\
\hline SUBTOTAL & $\therefore 80: 51$ & 9.22 & 17.23 & 22.24 & & & 129.98 & 259.18 \\
\hline \multicolumn{9}{|l|}{ COMMERCIAL : } \\
\hline Space Heat & 16.59 & 4.03 & 3.08 & 2.82 & & & 6.34 & 32.86 \\
\hline Water Heat & 1.51 & .32 & & .16 & & & 1.43 & 3.42 \\
\hline Cooking & 2.73 & & & & & & .48 & 3.21 \\
\hline Air cond. & & & & & & & 14.63 & 14.63 \\
\hline Mis. Electric & & & & & & & 43.80 & . 43.80 \\
\hline outdoor lighting & & & & & & & 3.85 & 3.85 \\
\hline SUBTOTAL & 20.83 & 4.35 & 3.08 & 2.98 & $\because$ & & 70.53 & 101.77 \\
\hline 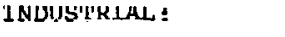 & & & & & & & & . \\
\hline Aluminum & 10.30 & & 21.25 & & 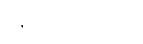 & & 52.20 & 83.75 \\
\hline Iron & & & & & & & & $\therefore$ \\
\hline steel. & 2.25 & & & & & & 1.18 & 3.43 \\
\hline Process Heat & 218.30 & 41.74 & 65.49 & & & & 4.37 & 329.90 \\
\hline Electric Drive & & & & & & & 116.74 & 116.74 \\
\hline Peedstocks & 54.27 & 162.82 & 29.60 & & : & . & & 246.69 \\
\hline Uranium Enrich. & & & & & & & 135.60 & 136.68 \\
\hline SUBTOTAL & 285.12 & 204.56 & 116.34 & & & . & 310.17 & 916.19 \\
\hline \multicolumn{9}{|l|}{ TRAHCFONTATION, } \\
\hline Automobile & & 310.95 & & & & & & 310.05 \\
\hline Truale \& Dus & & $2714 ?$ & & & & & & .231 .42 \\
\hline Rail \& Transit & & 21.27 & & & & & & 21.27 \\
\hline Air & & 26.92 & & & & & & 26.92 \\
\hline Pipelines & 14.09 & & & & & & & 14.09 \\
\hline ohip & & In kf & & & & & & 20.66 \\
\hline SUBTOTAL & 14.09 & 611.21 & & & & & & 625.31 \\
\hline $\begin{array}{l}\text { EIEC: UTILITY } \\
\text { Methane grod. }\end{array}$ & & 30.25 & 923.20 & & 485.67 & 178.21 & $(517.18)$ & $11.00 .15^{\mathrm{C}}$ \\
\hline coal. Prod. & & & 32.83 & & & & & 32.83 \\
\hline Refinery Use & '. & 6.41 & & . & & & & 6.41 \\
\hline Agriculture & 3.84 & 1.09 & & .3 .20 & & & 2.73 & $1 \quad 10.88$ \\
\hline Mining & 9.90 & 6.36 & 1.55 & & & & 3.71 & 21.52 \\
\hline $\begin{array}{l}\text { TOTAL RESOURCES } \\
\text { CONSUMED }\end{array}$ & 414.29 & 873.46 & 1094.23 & 28.48 & 485.67 & 178.21 & & 3074,34 \\
\hline
\end{tabular}

aHydroelectric output is converted to theoretical energy inputs based on' the equivalent coal-steam electric heat rate.

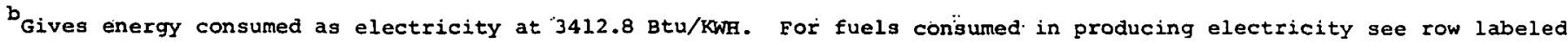
"Electric Utility."

craken as total resources consumed by utilities less electricity delivered to end use. 
Table A-3

Summary of Energy Demand and Fuèl Mix, 1985

Region: Tennessee Valley Authority

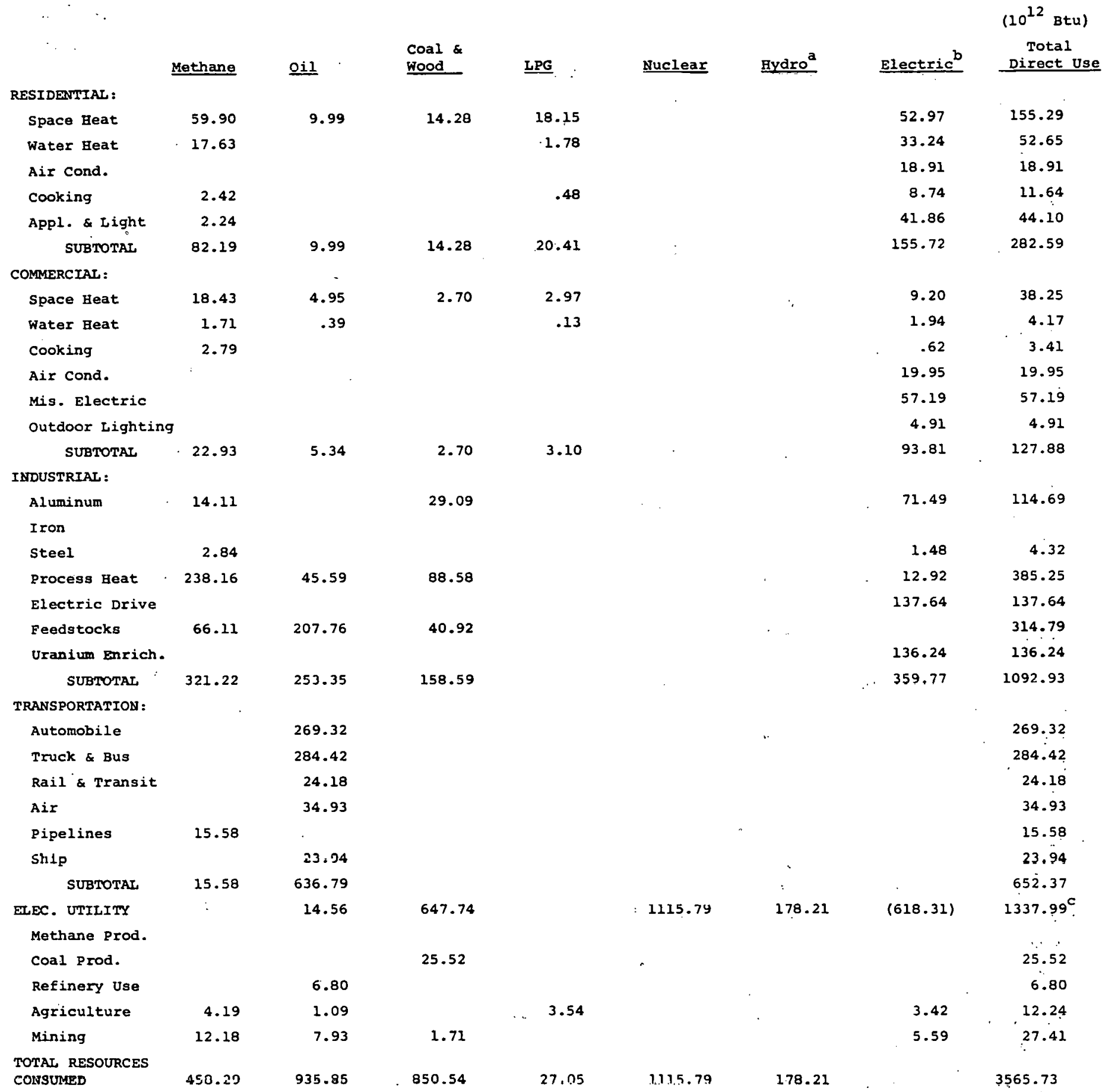

"Hydroelectric output is converted to theoretical energy inputs based on the equivalent coal-steam electric heat rate."

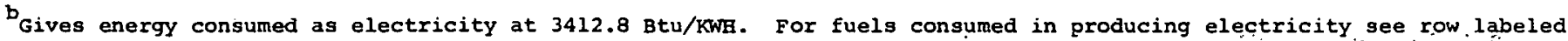
"Electric Utility."

CTaken as total resources consumed by utilities less electricity delivered to end use. 
Table A-4

Summary of Energy Demand and Fuel Mix, 2000

Region: Tennessee Valley, Authority.

\begin{tabular}{|c|c|c|c|c|c|c|c|c|}
\hline & Methane & Oi1 & $\begin{array}{l}\text { Coal \& } \\
\text { Wood }\end{array}$ & $\underline{\text { LPG }}$ & Nuclear & Bydro & Electric & $\begin{array}{c}\left(10^{12} \text { Btu }\right) \\
\text { Total } \\
\text { Direct Use }\end{array}$ \\
\hline \multicolumn{9}{|l|}{ RESIDEATIAI : } \\
\hline Space Heat & 62.63 & 11.66 & 6.63 & 17.69 & & & 73.10 & 171.71 \\
\hline Water Beat & 17.95 & & & 1.11 & & & 46.22 & 65.28 \\
\hline Air cond. & & & & & & & 30.79 & 30.79 \\
\hline cooking & & & & & & & 12.36 & 12.36 \\
\hline Appl. \& Light & 1.95 & & & & & & 63.01 & 64.96 \\
\hline SUBTOTAL & 82.53 & 11.66 & 6.63 & 18.80 & & & 225.48 & 345.20 \\
\hline \multicolumn{9}{|l|}{ COMGRCIAL : } \\
\hline Space Beat & 24.85 & 8.75 & 1.91 & 3.50 & & & 21.36 & 60.37 \\
\hline water itat & 2.13 & .38 & & .12 & & & 4.35 & 7.18 \\
\hline Cooking & 2.90 & & i & & & & 1.19 & 4.09 \\
\hline Air cond. & & & & & & & 39.16 & 39.16 \\
\hline Mis. Electric & & & & & & & 113.28 & 113.28 \\
\hline Outduor Lighting & & & & & & & 9.50 & 9.50 \\
\hline SUBTOTAL & 29.88 & 9.33 & 1.91 & 3.62 & & & 188.84 & 233.58 \\
\hline \multicolumn{9}{|l|}{ INLUS'I'KLAL： } \\
\hline Aluminum & 34.54 & & 58.95 & & & & 145.51 & 239.00 \\
\hline \multicolumn{9}{|l|}{ Iron } \\
\hline Steel & 3.97 & & & & & & 2.08 & 6.05 \\
\hline Process Heat & 310.38 & 54.77 & 195.10 & & & & 41.38 & 601.63 \\
\hline Electric Drive & & & & & & & 217.14 & 217.14 \\
\hline Feedstocks & 115.56 & 375.58 & 86.67 & & & & & 577.81 \\
\hline Oranium Enrich. & & & & & & & 136.61 & 136.61 \\
\hline SUBTOTAI & 464.45 & 430.35 & 340.72 & & & & 542.72 & 1778.24 \\
\hline TRATSPORTATIOM, & & & & & . & & & \\
\hline Automobilo & & 276.14 & & & & & & $275: 44$ \\
\hline Truor. a Dug & & A45.5? & - & & & & & 446.53 \\
\hline Rail \& Transit & & 34.03 & & & & & & 34.03 \\
\hline Air & & 79.51 & & & & & & 79.51 \\
\hline Pipelines & 21.26 & & & & & & & 21.26 \\
\hline Ship & & 34.47 & & & & & & 34.47 \\
\hline EUDTOTAL & 31.36 & 870.98 & & & & & & 093.21 \\
\hline ETEC. UTILITY & & 21.00 & 1080.66 & & 1770.24 & 178.21 & $(977.41)$ & $2072.70^{c}$ \\
\hline Methane Prod. & & & & & & & & \\
\hline Coal Prod. & & & 44.33 & & & & & 44.33 \\
\hline Refinery Use & & 9.92 & & & & & & 9.92 \\
\hline Agriculture & 5.92 & 1.50 & & 4.9 .3 & & & 6.41 & 18.76 \\
\hline Mining & 21.21 & 13.12 & 3.32 & & & & 13.96 & 51.61 \\
\hline $\begin{array}{l}\text { TOTAL RESOURCES } \\
\text { CONSUMED }\end{array}$ & 625.25 & 1367.86 & 1477.57 & 27.35 & 1770.24 & 178.21 & & 5446.48 \\
\hline
\end{tabular}

2Hydroelectric output is converted to theoretical energy inputs based on the equivalent coai-steam electric heat rate.

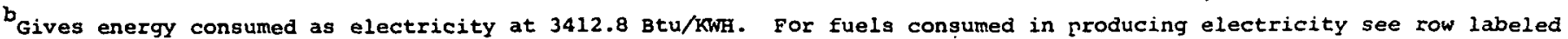
"Electric Utility."

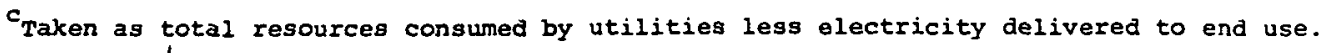


APPENDIX B

FUEL MIX TABLES

The projections of energy, demand and fuel mix for the reference years are developed on the worksheets included in this Appendix. The following parameters are specified in these "Fuel Mix Tables" for each demand category: Fuel Demand $\left(D_{i}\right)$; Total Fuel Demand (D), Relative Effectiveness $\left(e_{i}\right)$, Basic Energy Demand (E), Degree of Saturation ( $S)$, Unit Basic Energy Demand $\left(E_{u}\right)$, Fuel Fraction $\left(f_{i}\right)$, and Basis. These terms are defined below. In the base year the Fuel Demand, Relative Effectiveness, Basis, and degree of Saturation are initially specified with other variables being derived. The Basic Energy Demand is independent of the fuels employed to satisfy that demand and is forecast into the future from the projected Basis and any changes that may be postulated in Saturation and Unit Basic Energy Demand. By specifying the Fuel Fraction and Relative Effectiveness, the Fuel Demands are derived from the Basic Energy Demand for each future reference year, thus defining the fuel mix. The projection methodology is further outlined in Section II. The parameters discussed above and computed in the Fuel Mix Tables are defined as follows:

1. Fuel Demand, ${ }_{i}=$ the quantity of a fuel, $i$, actually consumed in a specific demand category, such as space heating, automotive transport, or aluminum production.

2. Total Fuel Demand, $D=$ the total fuel required to satisfy the requirements of a specific demand category. Electricity is considered as a fuel in this sense and $\mathrm{D}=\sum \mathrm{D}_{\mathrm{i}}$.

3. Relative Effectiveness, $\mathbf{e}_{\boldsymbol{i}}$ = the relative effectiveness with which fuel, $i$, is used in a demand category. This parameter depends on the utilization technology employed. See discussion in Section II.

4. Basic Energy Demand, $E$ = the amount of energy that would be required in a specific demand category, assuming a relative effectiveness, $e_{i}$, of $100 \%$ for each fuel employed. Thus, for a given demand category where quantities of fuels, $D_{i}$, are consuned with actual Relative Effectiveness, $e_{i}, E=\sum e_{i} D_{i}$ 
5. Degree of Saturation, $S$ = the fraction of the potential demand for a particular energy use actually being fulfilled at a given time. For example, if $95 \%$ of all households have refrigerators, and potentially all houses can have one refrigerator, $\mathrm{S}=0.95$.

6. Saturated Basic Energy Demand = the Basic Energy Demand that would exist in a category if there was $100 \%$ saturation, $=\mathrm{E} / \mathrm{S}$.

7. Unit Basic Energy Demand, $E_{u}=$ the Basic Energy Demand per unit (e.g., per household, per lb of Aluminum Produced, etc.).

8. Fuel Fraction, $f_{i}=$ fraction of the Saturated Basic Energy Demand that is satisfied by using the $i$ 'th fuel, $f_{i}=\frac{e_{i} D_{i}}{\text { E/S }}$ and $\sum_{i} f_{i}=S$ 
PROJECTED FUEL MIX

Sector: Residential

Region: TENNESSEE VALLEY AUTHORITY

Category: Space Heating

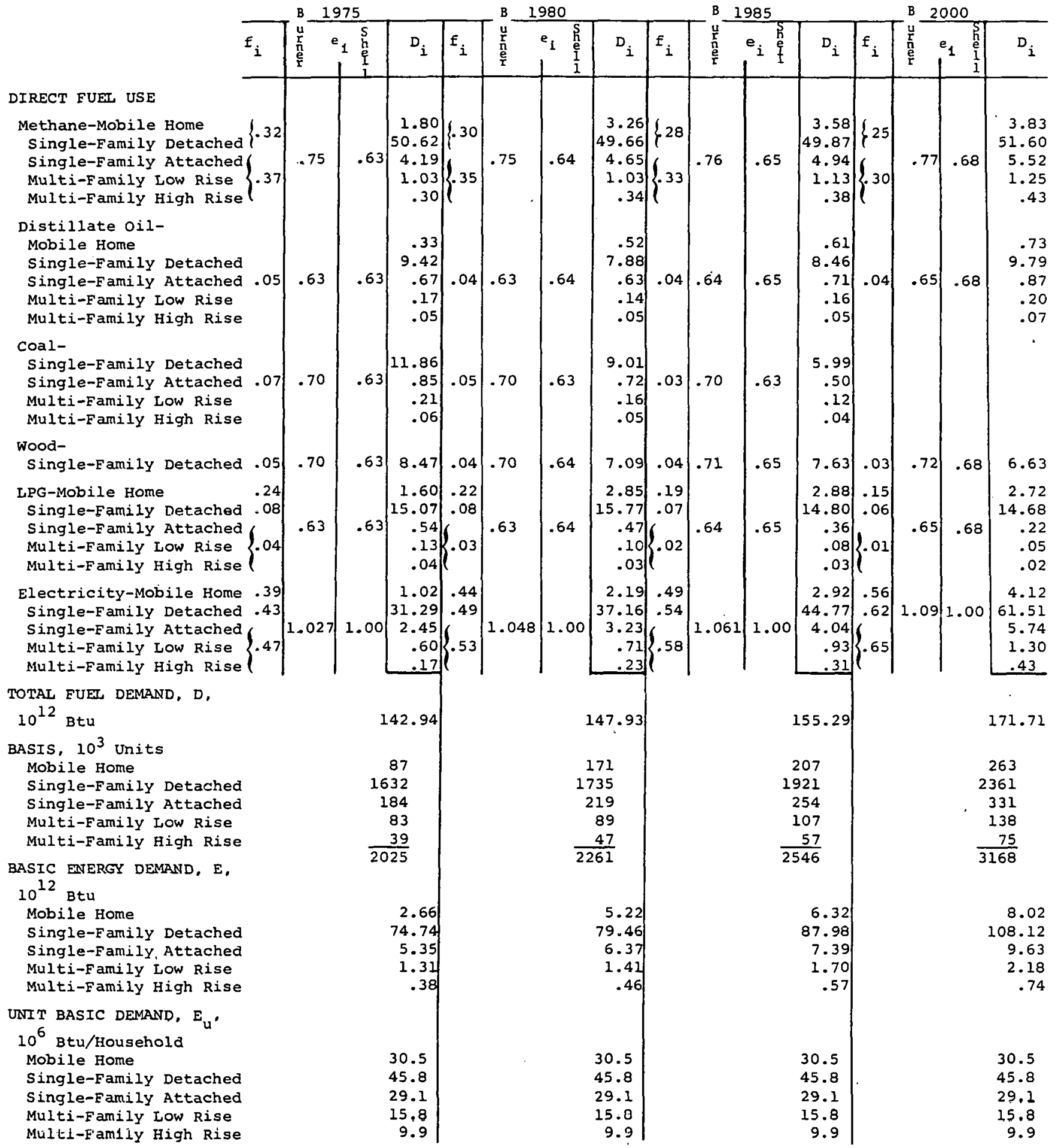


REFERENCE TECHNOLOGIES: Burner devices for fossil fuels, electric resistance heat, and heat pumps.

DATA SOURCES: $D_{i}$ (for 1975): Annual energy requirements per housing unit for five building types from Ref. (1) adjusted for average annual population weighted heating degree days in the TVA region.

$e_{i}: \quad$ Fossil fuel burner efficiencies from Ref. (6). No burner loss assumed for electric resistance heat. Seasonal performance factor for heat pumps, assumed to be 1.60 , is weighted in proportion to the number of heat pumps to obtain an average efficiency for all electric heating. The apparent relative shell effectiveness of an electrically heated home set at 1.00. Shell effectiveness of other buildings reflects reduced insulation and other building practices typical of conventional houssing units.

$f_{1}$ : Fuels for space heating as reported by TVA.

BASIS OF PROJECTIONS: qhe Dasle lemands derived for 1979 are escalated in proporelun Lu Llé number of households: Total number of households and number of electrically heated homes projected based on data reported by TVA. Space heating from fossil fuels projected to proportionally decrease with coal mecting less than $1 \%$ of demand in 2000. Housing units constructed after 1985 assumed to meet ASHRAE 90-75 standards. Retrofitting in one-half of all residential buildings constructed prior to 1975 such that they meet ASHRAE 90-75 standards by 2000. 


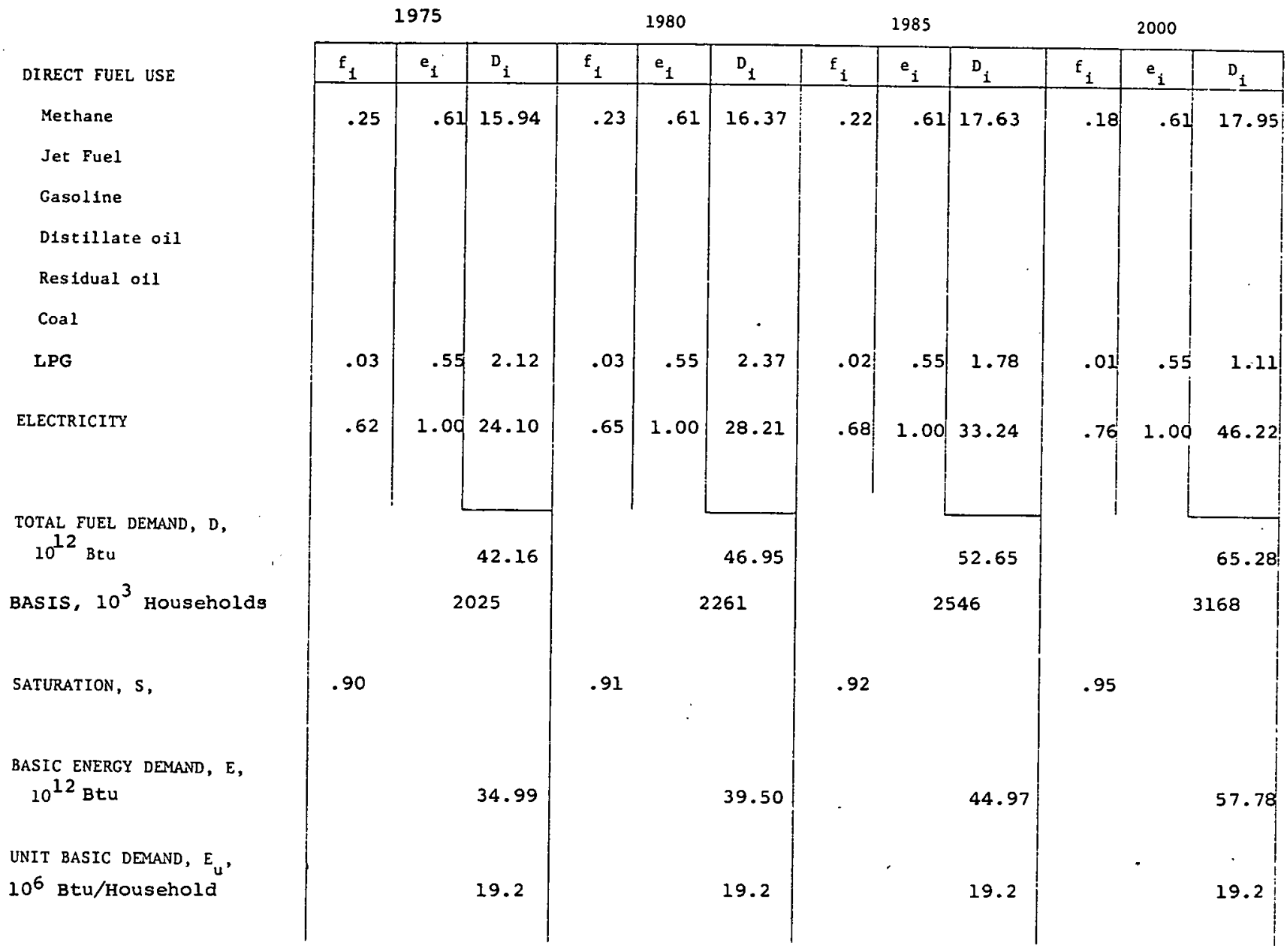

REFERENCE TECHNOLOGIES: Gas and oil burners, electric resistance heat.

DATA SOURCES: $D_{i}$ and $f_{i}$ (for 1975): Btu/Household requirements from Ref(1); fuels for water heating derived from Bureau of Census data (Ref 2).

$$
\text { ei: }
$$

BASIS OF PROJECTIONS :
These are apparent relative efficiencies derived from Btu/Household requirements assuming electric units have an apparent efficiency of 1.00 .

The basic demands derived for 1975 are escalated in proportion to the number of households projected for the reference years. The fuel mix is projected according to the changes forecast for space heat. 
DIRECT FUEL USE

Methane

Jet Fuel

Gasoline

Distillate oil

Kesidual oil

Coal

Other

ELECTRICITY , ROOM Central

TOTAL FUEL DEMAND, D, $10^{12}$ BtU

BASIS, $10^{3}$ Households

SATURATION, S, ROOM

Central

BASIC ENERGY DEMAND, E,

$10^{12} \mathrm{Btu}$. ROOm Central

UNIT RAST, DEMAND, Eu, $1 n^{6}$ R+1,/Hnisghola RoOm Central

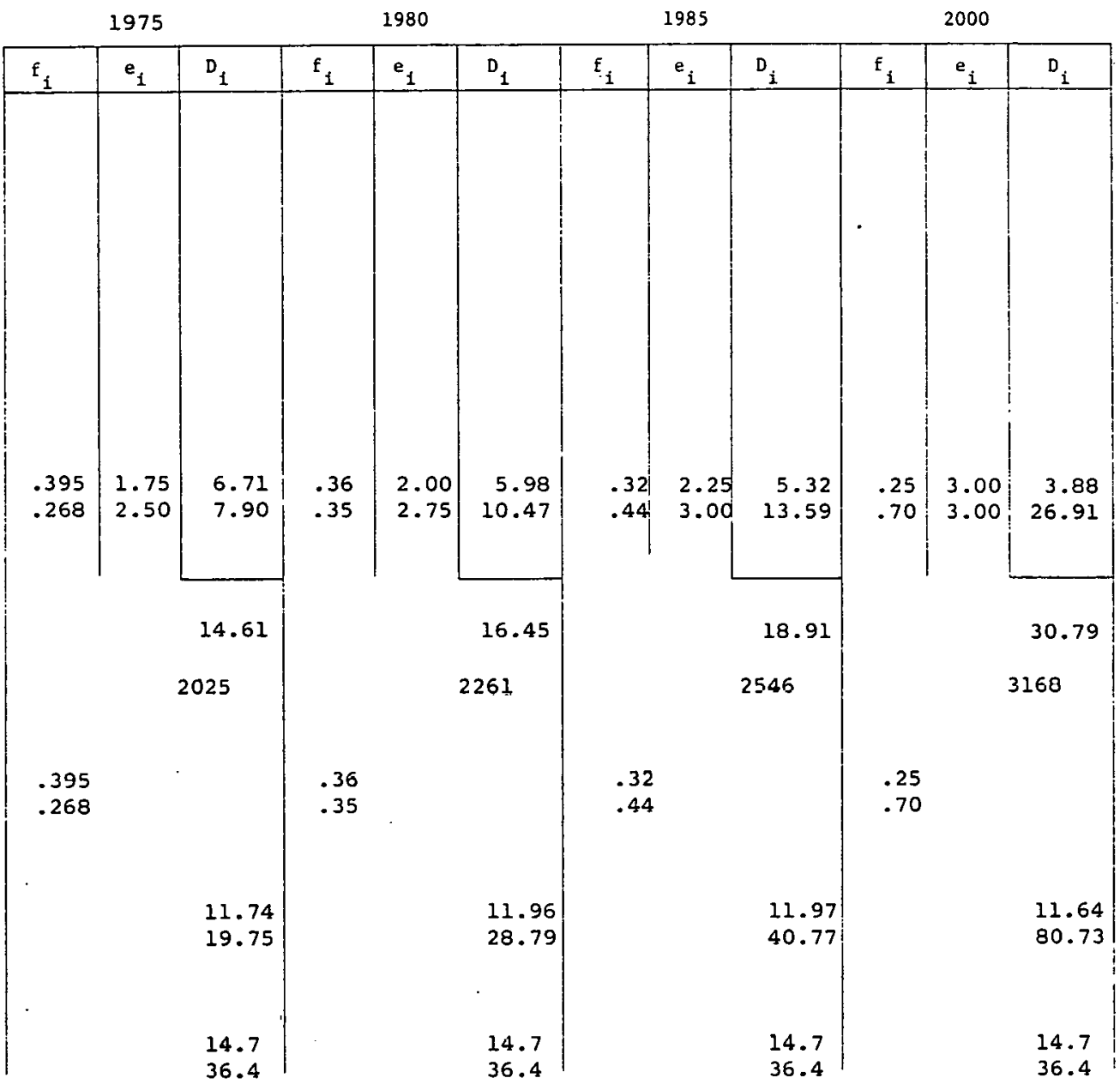

REFERENCE TECHNOLOGIES: Vapor compression cycle operating on electricity.

DATA SOURCE: $D_{1}$ and $f_{i}$ (for 1975):

Energy demand for room and central $\mathrm{A} / \mathrm{C}$ in the U.S. from a report by ORNL (Ref 3). Regionalized energy demand proportional to equivalent full load operating hours in the TVA service area (1200 hours as derived from Ref 41) relative to the U.S. (1000 hours from Ref 1) Market saturation of $\mathrm{A} / \mathrm{C}$ derived from Census of Housing and Annual Housing survey data (References 2 and 42 ).

$e_{1}:$

The effiniensy in thic domand eategory is the cuefflelent of performance for air conditioning equipment. The 1975 values for central units are taken from ASHRAE Guide and nat.a Rnnk, vmerjian society of Heating, Refrigeration, and Air conditioning Engineers, 1969, p. 514. The 1975 values for room $A / C$ are estimated from a report by ORNL (Ref 41). The snoffioient of porformance is increased in future reference years to reflect the use of the more efficient devioes that are on the market today.

BASIS OF PROJECTIONS :

The basic demands derived for 1975 are escalated in proportion to the market saturation and the number of households projected in the reference years. 
DIRECT FUEL USE

Methane

Jet Fuel

Gasoline

LPG

Residual oil

wood, coal

Other

ELECTRICITY

TOTAL FUEL DEMAND, D, $10^{12} \mathrm{BCU}$

BASIs, $10^{3}$ Households

SATURATION, S,

BASIC ENERGY DEMAND, E, $10^{12} \mathrm{Btu}$

UNIT BASIC DEMAND, $E_{u}$, $10^{6}$ Btu/Household

\begin{tabular}{|c|c|c|c|c|c|c|c|c|c|c|c|}
\hline \multicolumn{3}{|c|}{1975} & \multicolumn{3}{|c|}{1980} & \multicolumn{3}{|c|}{1985} & \multicolumn{3}{|c|}{2000} \\
\hline $\mathrm{f}_{1}$ & $e_{1}$ & $\mathrm{D}_{\mathbf{i}}$ & $\mathrm{f}_{1}$ & $e_{i}$ & $D_{1}$ & $\mathrm{~F}_{i}$ & $e_{i}$ & $D_{i}$ & $\mathrm{f}_{i}$ & $e_{i}$ & $\mathrm{D}_{1}$ \\
\hline .17 & .41 & 3.27 & .14 & .41 & 3.01 & .10 & .41 & 2.42 & & & . \\
\hline .04 & .41 & .77 & .03 & .41 & .65 & .02 & .41 & .48 & & & \\
\hline .02 & .44 & .36 & .01 & .44 & .20 & & & & & & \\
\hline .77 & 1.00 & 6.08 & .82 & 1.00 & 7.23 & .88 & 1.00 & 8.74 & 1.00 & 1.00 & 12.36 \\
\hline & & 10.48 & & & 11.09 & & & 11.64 & & & 12.36 \\
\hline & & 25 & & & 61 & & & 546 & & & 168 \\
\hline & & 7.89 & & & 8.82 & & & 9.93 & & & 12.36 \\
\hline & & 3.9 & & & 3.9 & & & 3.9 & & & 3.9 \\
\hline
\end{tabular}

REFERENCE TECHNOLOGIES: Burner devices for fossil fuels, electric resistance heat.

DATA SOURCES :

$D_{i}$ and $f_{i}$
$e_{i}:$

BASIS OF PROJECTIONS: (for 1975): Btu/Household requirements from Ref. (1). Fuel fraction derived from Census of Housing and Annual Housing Survey data (References 2 and 42).

Apparent relative efficiencies for methane and LPG are derived from Btu/Household requirements assuming oloctris units have an efficienry of 1.00. Apparent relative efficiency of wood and coal set equal to that in the residential space heating category.

The basic demand for 1975 is escalated in proportion to the number of households projected in the reference years. The fuel fraction is projected in proportion to the increasing market penetration of electric ranges and the corresponding decreasing use of methane, LPG, wood, and coal for cooking. The shift observed from 1970 to 1975 (Reforences 2 and 42) is assumed to continue such that by the year 2000 electric ranges have completely saturated the market. 


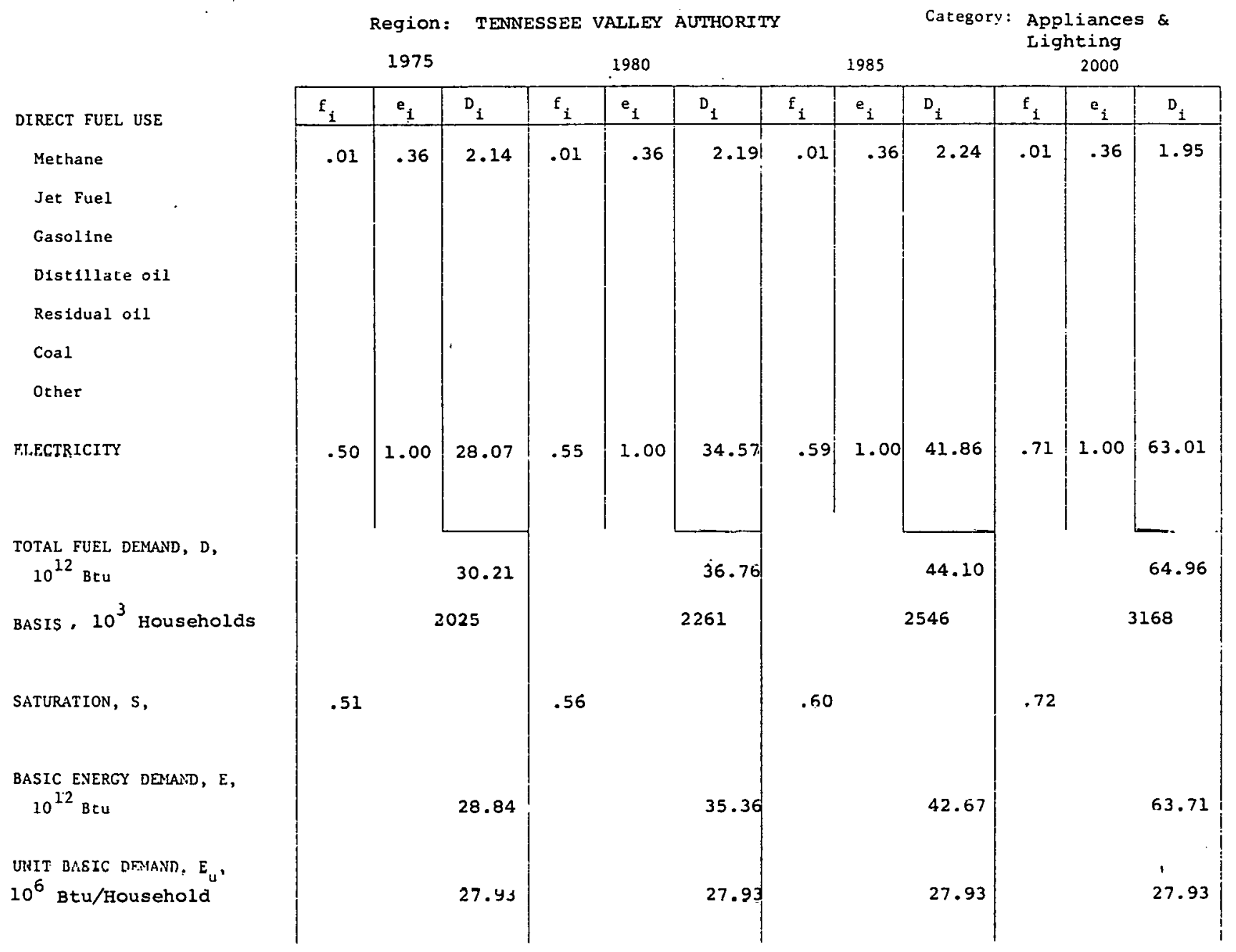

RPFFRENCE TECHNOLOGIES: Vapor compression cyele in refrigeration: AC 1nduction mulus in appliances; 1075 mix nf liqhting and of vacuum tube, transistor and integrated cirouits in electronic equipment.

DATA SOURCES: $D_{i}$ and $f_{i}$.

(for 1975):

Summarized in Table . Btu/household requirements from Ref. (1). The saturation factor is derived from 1970 census data (Ref. 2) escalated to 1975 .

$$
a_{1}
$$

Only non-elescll appliannes are qas clothes dryers. $e_{i}$ is an appaseit rolatlve effiaienry derived from Btij/nouselusld roquiraments assuming electric appliances have an apparmut efficionry of 1.00 .

BASIO OF BROJFCTIONS ;

The basic demands derived for 1975 aro escalated in proportion to the projected market perietration of appliances derived from Ref. (1). and tho number of households projected in the reference years. In 2000 new residential electrical devices not yet in use aro assumed to use as much energy as small appliances did in $1970\left(1.6 \times 10^{6} \mathrm{Btu} /\right.$ Household $)$. 
PROJECTED FUEL MIX

Region: TENNESSEE VALLEY AUTHORITY
Sector: commercial

Caregory: Space Heating

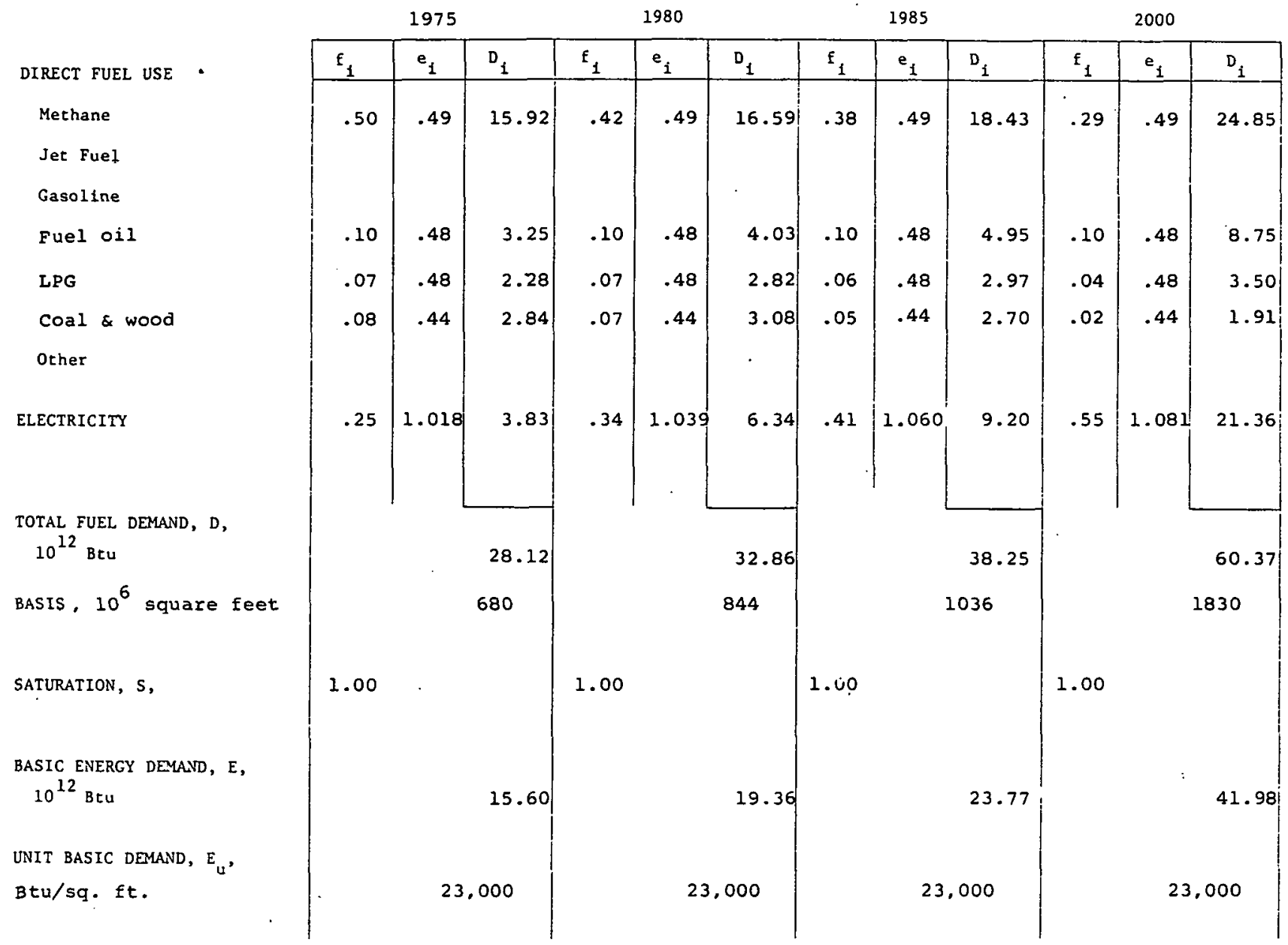

REFERENCE TECFNOLOGIES: Burner devices for fossil fuels, electric resistance heat, and heat pumps.

DATA SOURCES: $D_{i}$ and $f_{i}$ (for 1975): Annual heating requirements per square foot for five commercial building types from Ref. (1), adjusted for population weighted degree day data for the TVA region. Fuel mix estimated relative to residential space heating.

$e_{i}:$

Fossil fuel burner efficiencies from Ref. (6). No burner loss assumed for electric resistance heat. Seasonal performance factor for heat pumps, assumed to be 1.60 , is weighted in proportion to the number of heat pumps to obtain an average efficiency for all electric heating. Relative effectiveness, $e_{i}$, is the product of the burner efficiency and the apparent relative shell effectiveness. The apparent relative shell effectiveness of an electrically heated building set at 1.00 . Shell effectiveness of other buildings reflects reduced insulation and other practices typical of conventional buildings.

BASIS OF PROJECTIONS :

The basic energy demand for 1975 is escalated in proportion to projected commercial floor space. Commercial floor space is escalated in proportion to projected output in the commercial sector in the U.S. from the BNL inputsutput model assuming 33.29 GNp growth rale. Tutal U.S. oucput in the commercial sector is regionalized to the TVA service area based on projected regional earnings in the commercial sector. $75 \%$ of new construction is assumed to have electric heating. 
PROJECTED FUEL MIX

Region: TENNESSEE VALLEY AUTHORITY
Secror: Commercial

Category: water Heating

DIRECT FUEL USE

Methane

Jet Fuel

Gasoline

Fuel oil

LPG

Coal

Other

ELECTRICITY

TOTAI, FIJET. DEMAND, D, In 12 BetI

BAsIs, $10^{6}$ square feet

SATURATION, S,

BASIC ENERGY DEMAND, E, $10^{12} \mathrm{BCu}$

UNIT BASIC DEMAND, $E_{u}$, Btu/sq. ft.

1975

1980

1985

2000

\begin{tabular}{|c|c|c|c|c|c|c|c|c|c|c|c|}
\hline$f_{i}$ & $\mathbf{e}_{\mathbf{i}}$ & $D_{1}$ & $\mathrm{f}_{i}$ & $e_{i}$ & $D_{1}$ & $\mathrm{f}_{\mathbf{i}}$ & $e_{i}$ & $\mathrm{D}_{\mathbf{i}}$ & $\mathbf{f}_{\mathbf{i}}$ & $e_{1}$ & $\mathrm{D}_{\mathrm{i}}$ \\
\hline .40 & .70 & 1.32 & .37 & .70 & 1.51 & .34 & .70 & 1.71 & .24 & .70 & 2.13 \\
\hline .07 & .54 & .30 & .06 & .54 & .32 & .06 & .54 & .39 & .05 & .54 & .58 \\
\hline .03 & .54 & .13 & .03 & .54 & .16 & .02 & .54 & .13 & .01 & .54 & .12 \\
\hline .45 & 1.00 & 1.04 & .50 & 1.00 & 1.43 & .55 & 1.00 & 1.94 & .70 & 1.00 & 4.35 \\
\hline & & 2.79 & & & 3.42 & & & 4.17 & & & 7.18 \\
\hline & & 680 & & & 844 & & & 1036 & & & 1830 \\
\hline .95 & & & .96 & & & .97 & & & 1.00 & & \\
\hline & & 2.20 & & & 2.75 & & & 3.42 & & & 6.22 \\
\hline & & 3400 & & & 3400 & & & 3400 & & & $34 \cap 0$ \\
\hline
\end{tabular}

REFERENCE TECHNOLOGIES: Bumer devices for tossil fuels and eleclril iesistancc heat.

DATA SOURCES: $D_{i}$ and $f_{i}$ (for 1975): Annual hot water requirements peir square ruut ful flve luilaing

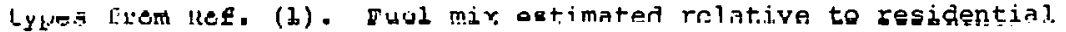
water heating.

$$
e_{i}:
$$

The relative efficiencies are held in the same ratio as is given in Ref. (6), p. 18 .

BASIS OF PROJECTIONS

The basic energy demand for 1975 is escalated in proportion to projccted commercial floor space. Changes in the fuel $\mathrm{mix}$ are projected relative to residential hut water heating. 
PROJECTED FUEL MIX

Region: TENNESSEE VALLEY AUTHORITY
Sector : Commercial

Category: cooking
DIRECT FUEL USE

Methane

Jet Fuel

Gasoline

Distillate o1l

Residual o1I

Coal

ocher

ELECTRICITY

TOTAL FUEL DEMAND, D, $10^{12} \mathrm{Btu}$

BASIS, $10^{6}$ meals

SATURATION, S,

BASIC ENERGY DEMAND, E, $10^{12} \mathrm{Btu}$

UNIT BASIC DEMAND, $E_{u}$, Btu/meal
19751980

1985

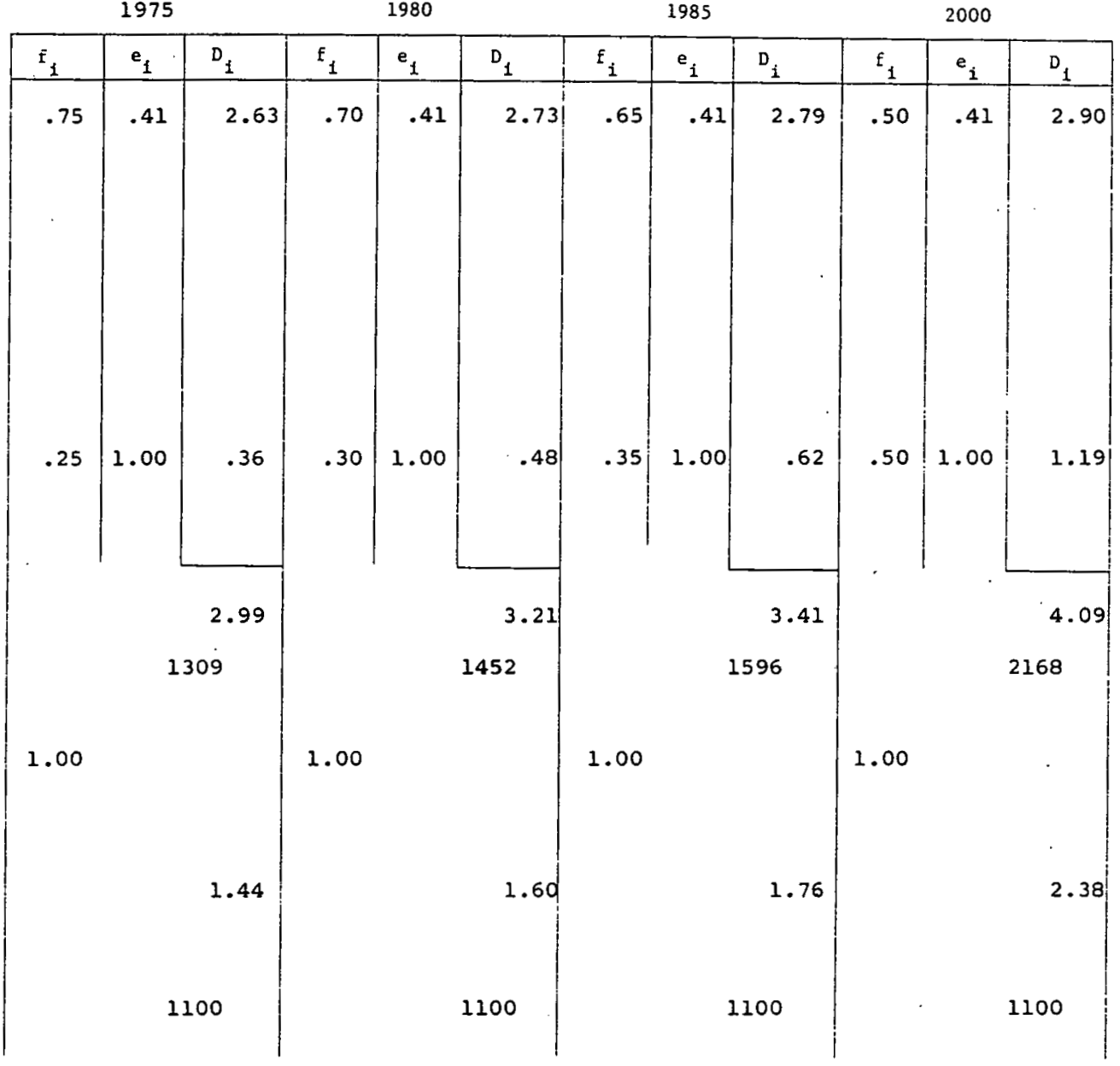

REF ERENCE TECHNOLOGIES :

DATA SOURCES :

$$
D_{i} \text { and } f_{i}
$$

Gas burner device and electric resistance heat.

Assume energy required to cook a meal' is $75 \%$ that of the residential sector and twenty percent of all meals are in commercial establishments.

Taken as equal to the apparent relative efficiencies in the residential cooking category.

The basic energy demand is escalated in proportion to the number of meals served. The number of meals served"is projected as a function of growth in population and the increasing proportion of meals eaten in commercial. establishments, projected to increase from $20 \%$ in 1975 to $25 \%$ in 2000. 
Region: TENNESSEE VALLEY AUTHORITY

\begin{tabular}{|c|c|c|c|c|c|c|c|c|c|c|c|c|}
\hline \multirow{3}{*}{$\begin{array}{l}\text { DIRECT FUEL USE } \\
\text { Methane }\end{array}$} & \multicolumn{3}{|c|}{1975} & \multicolumn{3}{|c|}{1980} & \multicolumn{3}{|c|}{1985} & \multicolumn{3}{|c|}{2000} \\
\hline & $\mathrm{f}_{1}$ & $e_{i}$ & $D_{1}$ & $f_{i}$ & $e_{1}$ & $D_{1}$ & $\mathrm{~F}_{i}$ & $e_{i}$ & $D_{i}$ & ${ }^{E_{1}}$ & $e_{i}$ & $D_{1}$ \\
\hline & & & & & & & & & & & & \\
\hline Jet Fue1 & & & & & & & & & & & & \\
\hline Gasoline & & & & & & & & & & & & \\
\hline Distillate ofl & & & & & & & & & & & & \\
\hline Residua1 ofl & & & & & & & & & & & & \\
\hline coal & & & & & & & & & & & & \\
\hline other & & & & & & & & & & & & \\
\hline ELECTRICITY & .72 & 2.50 & 10.18 & .81 & 3.50 & 11.63 & .00 & 2.50 & 19.05 & 1.00 & 2.50 & 39.10 \\
\hline $\begin{array}{l}\text { TOTAL FUEL DEMAND, D, } \\
10^{12} \text { Btu }\end{array}$ & & & 10.48 & & & 14.63 & & & 19.95 & & & 39.16 \\
\hline BASIS, $10^{6}$ square feet & & & 680 & & & 844 & & & 1036 & & & 1830 \\
\hline SATURATION, $s$, & .72 & & & .81 & & & .90 & & & 1.00 & & \\
\hline $\begin{array}{l}\text { BASIC ENERGY DEMAND, E, } \\
10^{12} \mathrm{Bru}\end{array}$ & & & 26.20 & & & 36.57 & & & 49.88 & & & 97.91 \\
\hline $10^{3} \mathrm{Btu} / \mathrm{sq}$. ft. & & & 53.5 & & & 53.5 & & & 53.5 & & & $53.3^{\circ}$ \\
\hline
\end{tabular}

REFERENCE TECHNOLOGIES: Vapor compression cycle.

DATA SOUTRCES: $\bar{D}_{i}$ and $f_{i}$ (for 1975): Annual energy requirements per square foot per building type
from Ref. (1). Regionalized to the TVA service area based on from Ref. (1). Regionalized to the TVA service area based on
equivalent Full load operating hours (1200) in the region from Ref. (41). Market penetration of $\mathrm{A} / \mathrm{C}$ is BNL estimate.

$$
e_{i}:
$$

BASIS OF PROJECTIONS:

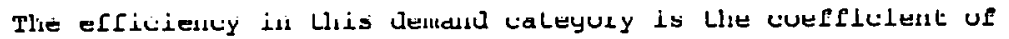
performance for air conditioning equipment.

The basic demands derived for 1975 are escalated in proportion to the market saturation and the number of households projected in the reference years. 
PROJECTED FUEL MIX
Region: TENNESSEE VALLEY AUTHORITY

ector: Commercial

Category: Lighting, Appliances \& Refrigeration 2000

DIRECT FUEL USE

Methane

Jet Fuel

Gasoline

Dietillate ofl

Residual o11

Coal

Other

ELECTRICITY

TOTAL FUEL DENAND, D, $10^{12} \mathrm{Btu}$

BAsIs, $10^{6}$ square feet

SATURATION, S,

BASIC ENERGY DEMAND, E, $10^{12}$ Btu

UNIT BASIC DEMAND, $E_{u}$,

Btu/sq. ft.

1975

1980 1985

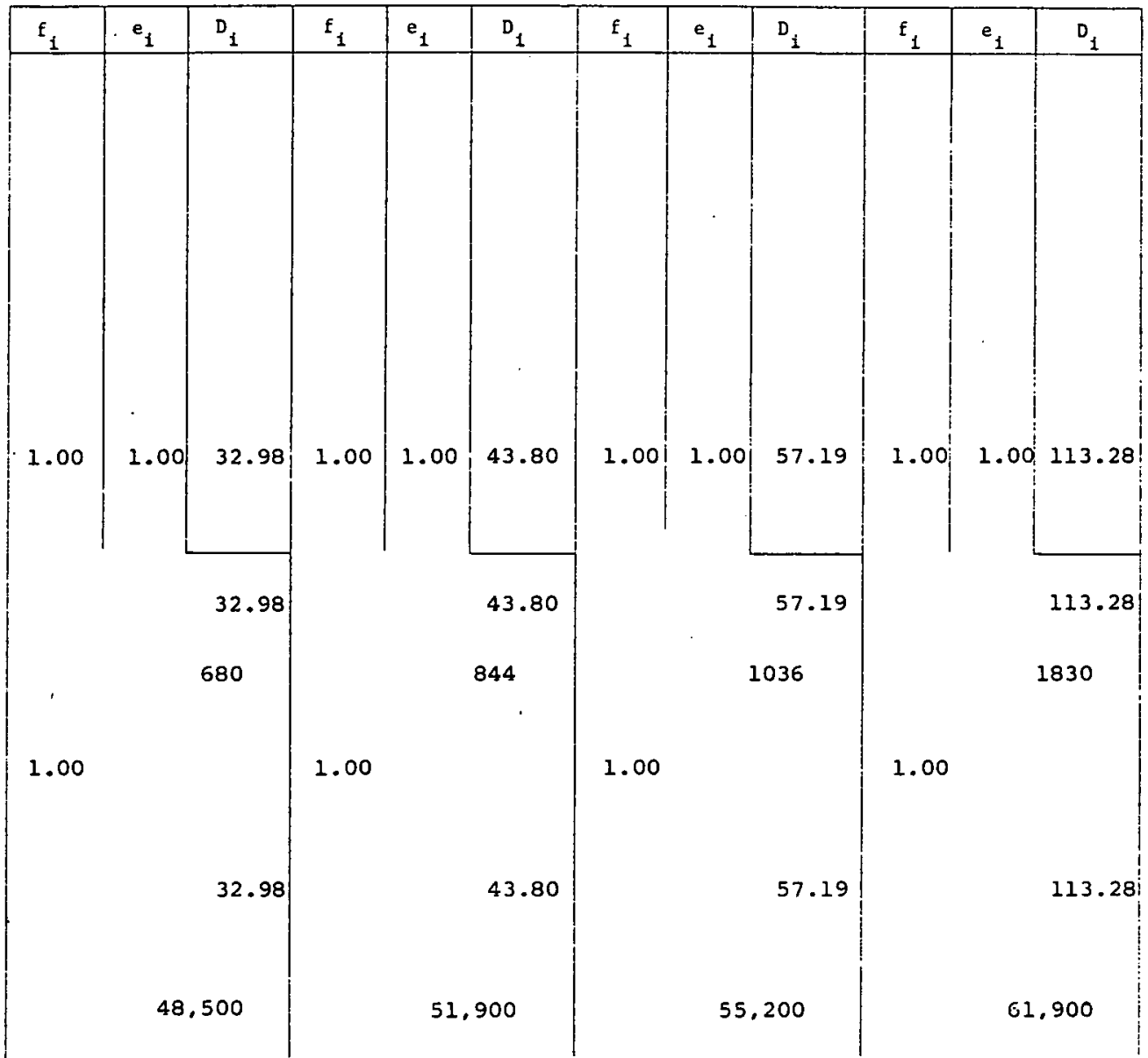

REFERENCE TECHNOLOGIES: Electric energy and vapor compression cycle.

DATA SOURCES: $D_{i}$ and $f_{i}$

$e_{i}:$

BASIS OF PROJECTIONS (for 1975): Annual energy requirements per square foot per building type for lighting, appliances, refrigeration, auxiliary space conditioning equipment, and computers from Ref. (1).

Taken as one since there is only one energy source employed.

The basic energy demand for 1975 is osalated ln proportion to projected commeilial flōor space and changes in the unit basic energy demand. Energy requirements for computers and refrigerating equipment increase by a factor of 1.5 by 1985 and 2.0 by 2000 . 
DIRECT FUEL USE

Methane

Jet Fuel

Gasoltne

Distillate oil

Residual of

Coal

other

ELECTRICITY

TOTAL FUEL DEMAND, D, $10^{12}$ B.tu

1975

1980 1985 2000

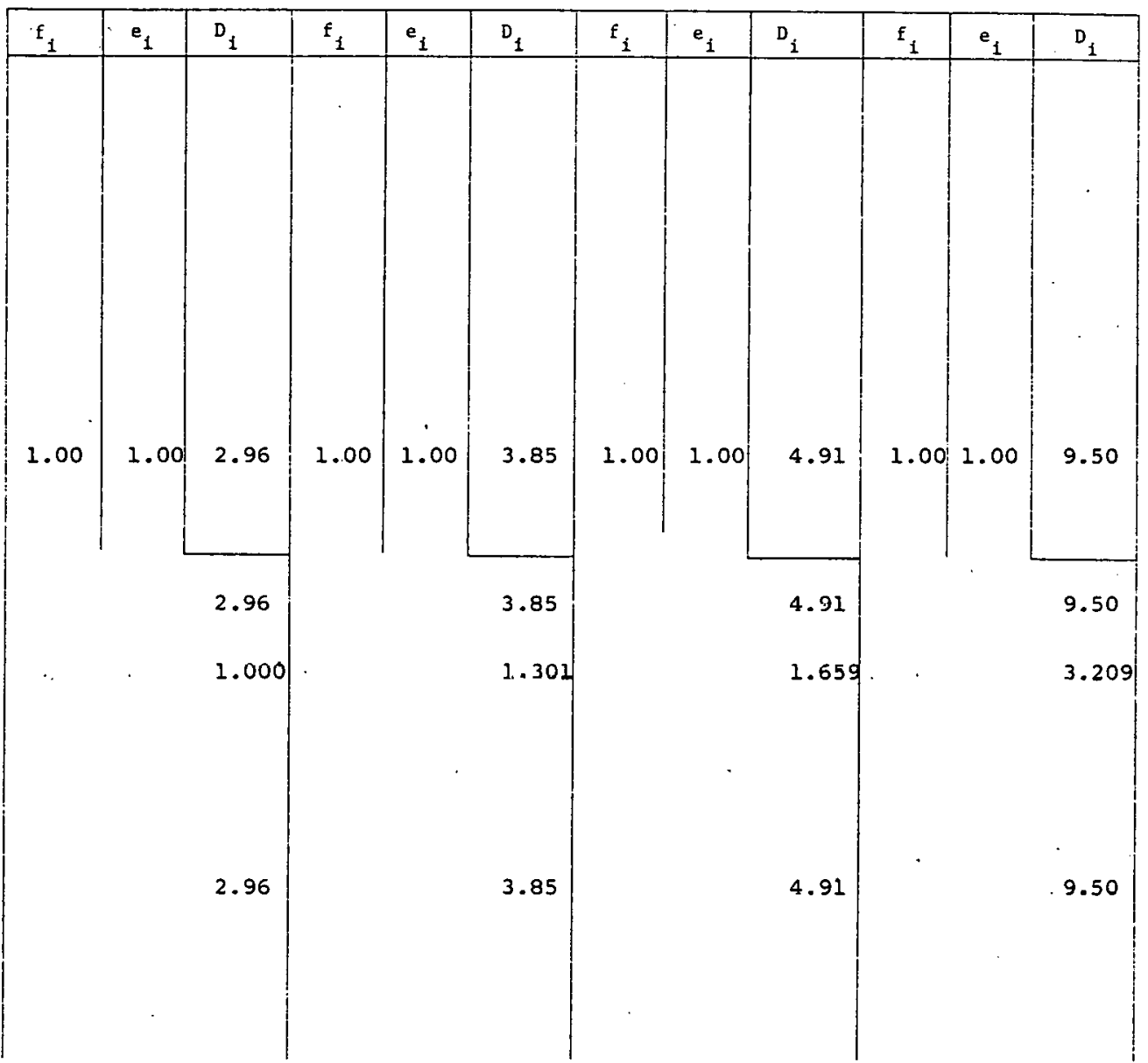

BASIC ENERGY DEMAND, E, $10^{12}$ BCU

WUIT BASIC DFMAND, $E_{u}$,

BASIS; Multiple of 1975

SATURATION, S,

REFERENCE TECHNULÜGTJ: InopndeAcent laup

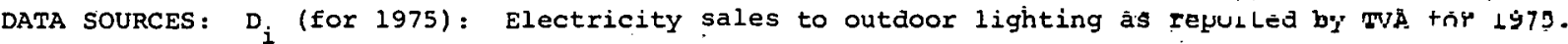
$e_{i}$ and $f_{i}$ : Taken as unity since there is only one energy source employed.

BASIS OF PROJECTIONS: Electricity sales to outdoor lighting as projected by TVA for 1980 and 1985 . Electricity sales to outdoor lighting. in the year 2000 is a BNL estimate. 


\section{Region: TENNESSEE VALLEY AUTHORITY}

DIRECT FUEL USE

Methane

Jet Fuel

Gaooline

Distillate o1l

Residual o1l

Coal

IPG

ELECTRICITY

TOTAL FUEL DEMAND, D, $10^{12} \mathrm{Btu}$

BASIS, Multiple of 1975

SATURATION, S,

BASIC ENERGY DEMAND, E, $10^{12} \mathrm{BCu}$

UNIT BASIC DERLAND, $E_{u}$,

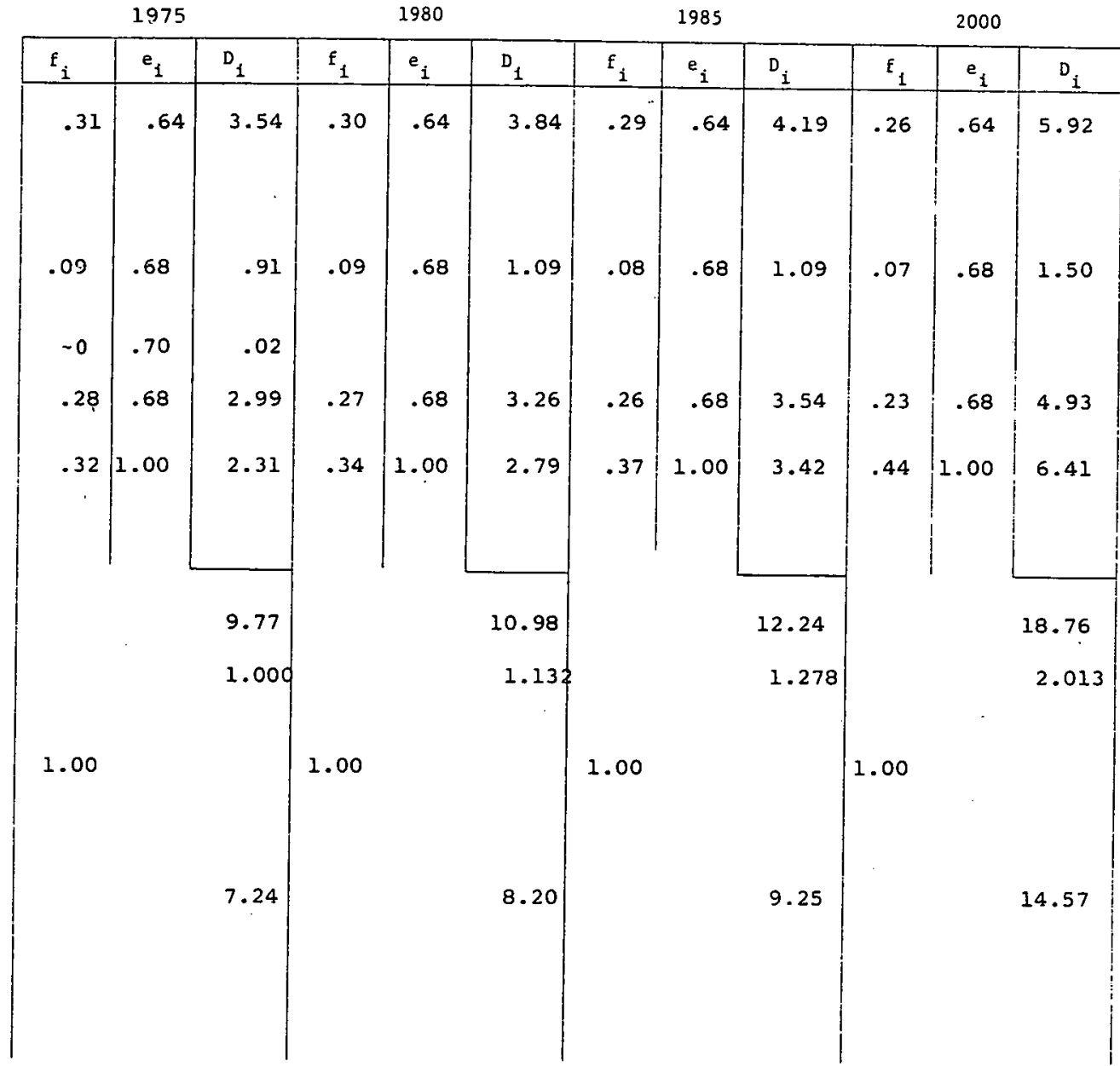

REFERENCE TECHNOLOGIES: Burner devices for fossil fuels, electric resistance heat, and a/c induction motors and pumps.

DATA SOURCES: $D_{i}$ and $f_{i}$ (for 1975): Demand for energy and fuel mix in the $U . S$. from the National Energy Accounts (Ref. 43). Regionalized based on farm acreage in the TVA service area relative to total U.S. acreage.

$e_{i}:$

BASIS OF PROJECTIONS:
Relative efficiencies set equal to those used for industrial process heat.

The baoie enesyy demand derived for 1975 is escalated in proportion to projected agricultural output in the U.S. from the BNL input-output model assuming a $3.2 \%$ GNP growth rate. U.S. ayrlcultural output is regionalized to the TVA. service area based on projected regional earnings in agriculture. 
Region: TENNESSEE VALLEY AUTHORITY

\begin{tabular}{|c|c|c|c|c|c|c|c|c|c|c|c|c|}
\hline \multirow[b]{2}{*}{ DIRECT FUEL USE } & \multicolumn{3}{|c|}{1975} & \multicolumn{3}{|c|}{1980} & \multicolumn{3}{|c|}{1985} & \multicolumn{3}{|c|}{2000} \\
\hline & $\mathrm{f}_{1}$ & $e_{1}$ & $D_{1}$ & $\mathrm{f}_{1}$ & $e_{i}$ & $\mathrm{D}_{1}$ & $f_{i}$ & $e_{i}$ & $D_{i}$ & $f_{1}$ & $e_{i}$ & $\mathrm{D}_{1}$ \\
\hline Methane & .43 & .64 & 7.66 & .41 & .64 & 9.90 & .39 & .64 & 12.18 & .35 & .64 & 21.21 \\
\hline $\begin{array}{l}\text { Jet Fuel } \\
\text { Gasoline }\end{array}$ & & & & & & & & & & & & \\
\hline Distillate ofl & .21 & .68 & 3.59 & .20 & .68 & 4.54 & .19 & .68 & 5.58 & .16 & .68 & 9.13 \\
\hline Residual oll & .09 & .68 & 1.42 & .08 & .68 & 1.82 & .08 & .68 & 2.35 & .07 & .68 & 3.99 \\
\hline Coal & .07 & .70 & 1.07 & .07 & .70 & 1.55 & .06 & .70 & 1.71 & .06 & .70 & 3.32 \\
\hline other & & & & & & & & & & & & \\
\hline ELECIAICIII & .30 & 1.00 & 2.26 & .24 & 1.00 & 3.71 & .28 & 1.00 & 5.59 & .36 & 1.00 & 13.96 \\
\hline $\begin{array}{l}\text { TOTAL FUEL DEMAND, D, } \\
10^{12} \mathrm{BEU}\end{array}$ & & & 16.00 & & & 21.52 & & & 27.41 & & & 51.61 \\
\hline BASIS, Multiple of 1975 & & & 1.000 & & & . 1.365 & & & 1.765 & & & 3.427 \\
\hline SATURATION, S, & 1.00 & & & 1.00 & & & 1.00 & & & 1.00 & & \\
\hline $\begin{array}{l}\text { BASIC ENERGY DEMAND, E, } \\
10^{12} \mathrm{Bt}, 1\end{array}$ & & & 11.32 & & & 15.45 & & & 19.98 & & & 38.79 \\
\hline UNIT BASIC DEMAND, $E_{\mathrm{u}}$, & & & & & & & & & & & & \\
\hline
\end{tabular}

BRTFRFNCE TFCHNOLOGIES: Burner devices tor fussil fuclg, olectric lesistango họt, and a/C Induction mntors.

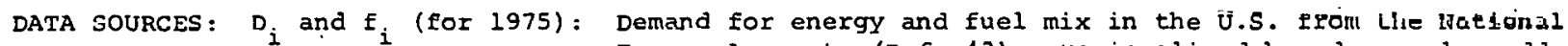
Energy Accounts (Ref. 43). Kegionalizcd based on value added in mining for the TVA service area relative to value added in mining for the U.S.

P.: Relative efficiencies set equal to those used for industrial prititso heat.

BASLS OF EROJEGTINAT

The basic energy demand derived for 1975 is escalated in proporclui to projected output from lluesal indugtries in the U.S.. estimated using the BNL input-oucpul ilodel assuming a $3.2 \%$ GNP growth rate. MInelal induotries oltput is regionalized to the TVA service area based ui projoctor regional earnings in mining. 


\begin{tabular}{|c|c|c|c|c|c|c|c|c|c|c|c|c|}
\hline \multirow[b]{2}{*}{ DIRECT FUEL USE } & \multicolumn{3}{|c|}{1975} & \multicolumn{3}{|c|}{1980} & \multicolumn{3}{|c|}{1985} & \multicolumn{3}{|c|}{2000} \\
\hline & $f_{i}$ & $e_{1}$ & $\mathrm{D}_{i}$ & $\mathrm{~F}_{1}$ & $e_{1}$ & $D_{1}$ & $f_{i}$ & $\mathrm{e}_{\mathbf{i}}$ & $\mathrm{D}_{i}$ & $\mathrm{f}_{i}$ & $e_{i}$ & $D_{i}$ \\
\hline Methane & .12 & .64 & 7.32 & .12 & .64 & 10.30 & .12 & .64 & 14.11 & .14 & .64 & 34.54 \\
\hline Jet Fuel & & & & & & & & & & & & \\
\hline Gasoline & & & & & & & & & & & & \\
\hline Dist1llate ofl & & & & & & & & & . & & & \\
\hline Residual ofl & & & & & & & & & & & & \\
\hline $\begin{array}{l}\text { coal - For carbon } \\
\text { Electrodes } \\
\text { Other }\end{array}$ & .30 & .75 & 15.62 & 0.29 & 0.75 & 21.25 & 0.29 & 0.75 & 29.09 & .28 & .75 & 58.95 \\
\hline $\begin{array}{c}\text { ELECTRICITY - Electrolysi } \$ \\
\text { Drive }\end{array}$ & $\begin{array}{l}.40 \\
.18\end{array}$ & $\begin{array}{l}.52 \\
1.0\end{array}$ & $\begin{array}{r}30.03 \\
7.03\end{array}$ & $\begin{array}{l}0.39 \\
0.20\end{array}$ & $\begin{array}{l}0.52 \\
1.0\end{array}$ & $\begin{array}{l}41.21 \\
10.99\end{array}$ & $\begin{array}{l}.39 \\
.20\end{array}$ & $\begin{array}{l}.52 \\
1.0\end{array}$ & $\begin{array}{l}56.44 \\
15.05\end{array}$ & $\begin{array}{l}.37 \\
.21\end{array}$ & $\begin{array}{l}.52 \\
1.0\end{array}$ & $\begin{array}{l}112.35 \\
33.16\end{array}$ \\
\hline $\begin{array}{l}\text { TOTAL FUEL DEMAND, } D \text {, } \\
10^{12} \text { BEU }\end{array}$ & & & 60.00 & & & 83.75 & . & & 114.69 & & & 239.00 \\
\hline $\begin{aligned} \text { Basis, } & 10^{9} \mathrm{lbs} . \text { Primary Ad } \\
& 10^{9} \mathrm{lbs} \text {. Scrap } \\
& 10^{9} \mathrm{lbs} \text {. Total }\end{aligned}$ & & & $\begin{array}{l}1.144 \\
0.289 \\
1.433\end{array}$ & & & $\begin{array}{l}1.57 \\
0.52 \\
2.09\end{array}$ & & & $\begin{array}{l}2.15 \\
0.71 \\
2.86\end{array}$ & & & $\begin{array}{l}4.28 \\
2.11 \\
6.39\end{array}$ \\
\hline SATURATION, s, & & & & & & & & & & & & \\
\hline $\begin{array}{l}\text { BASIC ENERGY DEMAND, E, } \\
10^{12} \mathrm{Btu}\end{array}$ & & & 39.05 & & & 54.95 & & & 75.25 & & & 157.90 \\
\hline $\begin{array}{l}\text { UNIT BASIC DEMAND, } E_{u} \text {, } \\
\text { Btu/lb. }\end{array}$ & & 27 . & 100 & & 26 , & 00 & & & 000 & & & 000 \\
\hline
\end{tabular}

REFERENCE TECHNOLOGIES: Electrolytic smelting, carbon cathodes and pot linings.

DATA SOURCES: $D_{i}$ and $F_{i}$ (for 1975):

$$
e_{i}:
$$

BASIS OF PROJECTIONS:
Energy totals for methane, coal, and electricity are BNL estimates for smelting and other primary and secondary processes plus foundry operations. Production level based on capacity data (Ref. 8).

The efficiency for methane use is taken from Ref. (6) for process steam production. The electrolytic efficiency is based on a minimum theoretical requirement of 27.3 million Btu per ton. Oxidation of carben al lite allude is accounted for in the losses to coal.

The total 1975 U.S. production from the Bureau of Mines is escalated at $5.6 \%$ per year to 1985 and $4.9 \%$ thereafter. The 19751985 rate is from Ref. (18); the 1985-2000 rate is cased on the 2000 total U.S. production forecast in Ref. (19). TVA production is adjusted, relative to U.S. production, by the ratio of TVA to J.S. earnings in manufacturing in the projected year divided by the TVA to U.S. earnings in 1970 (Ref. 17). Scrap represents 25\% of the total through 1985 and is increased to $33 \%$ thereafter. 
DIRECT FUEL USE

Methane

Jet Fuel

Gasoline

Distillate oil

Residual ofl

Coal

Other

ELECTRICITY

Electric Furnace

TOTAL FUEL DEMAND, D, $10^{12}$ Btu

BASLS, $10^{3}$ short tons

SATURATION, S,

BASIC ENERGY DEMAND, E, $10^{12}$ Btu

UHIT BASIC DEMAND, F $10^{3} \mathrm{Btu} /$ ton

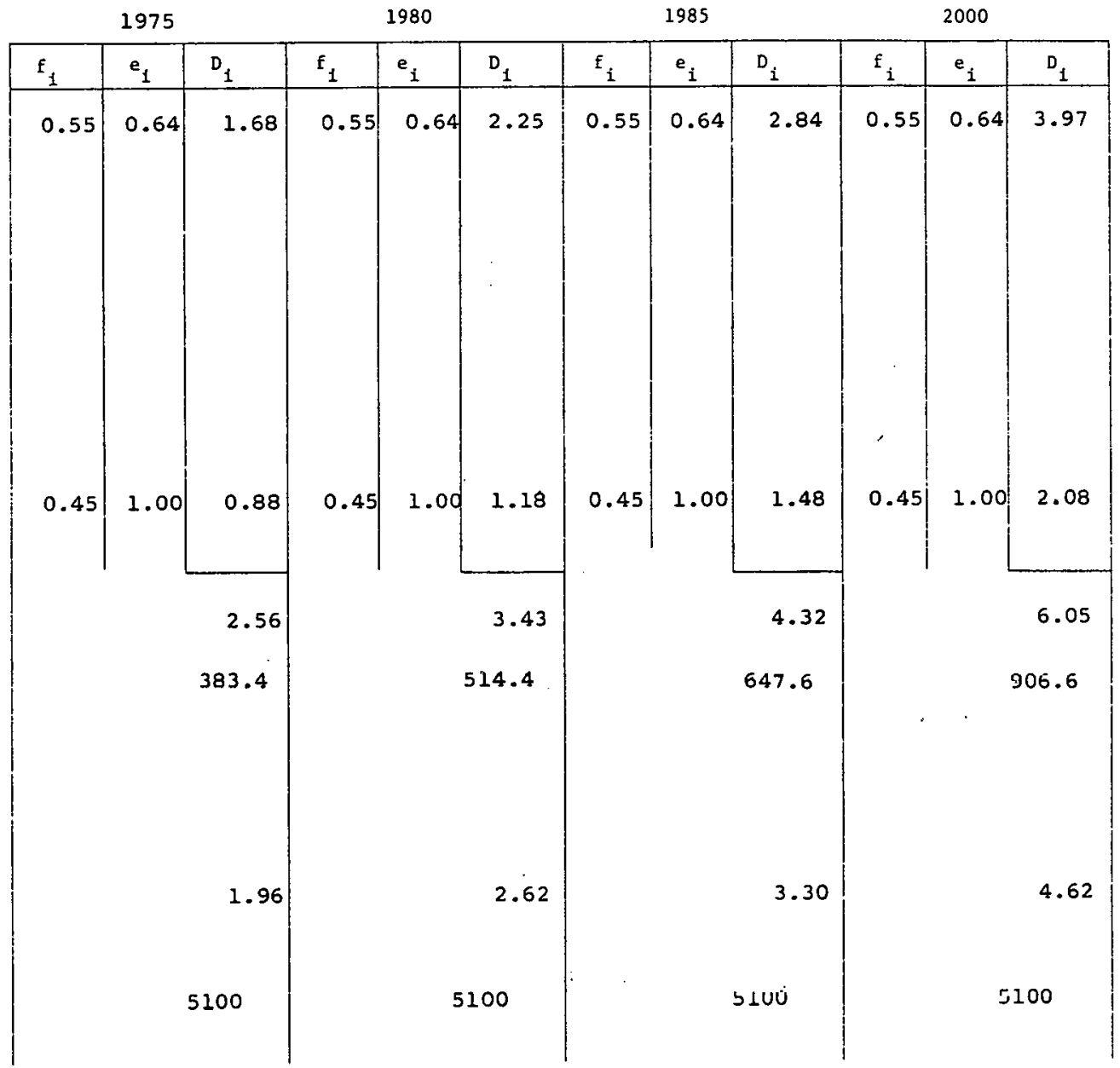

REFERENCE TECHNOLOGIES: Electric furnace.

DATA SOURCES: $D_{j}$ and $f_{i}$ (for 1975):

Energy requirements tor the electidc furnace from Rof. (6) and aul AUI cotimatol. Drontirtinn level from survey of plants in IVA region and AUI estimates.

$$
e_{i}:
$$

Reference (6), p. 18 .

BASIS OF PROJECTIONS:

Production is escalated in proportion to AUI steel projections for the U.S.. adjusted by the ratio of TVA to U.S. earrings in primary matals in the projected year divided by the IVA to U.s. earningo in 1970 (Ref. 17). 
2000

DIRECT FUEL USE

Methane

Jet Fuel

Gasol1ne

Fuel oil

Coal

Other

ELECTRICITY

TOTAL FUEL DEMAND, D, $10^{12}$ Btu

BASIS, Multiple of 1975

SATURATION, S,

BASIC ENERGY DEMAND, E, $10^{12} \mathrm{Btu}$

UNIT BASIC DEMAND, $E_{u}$,

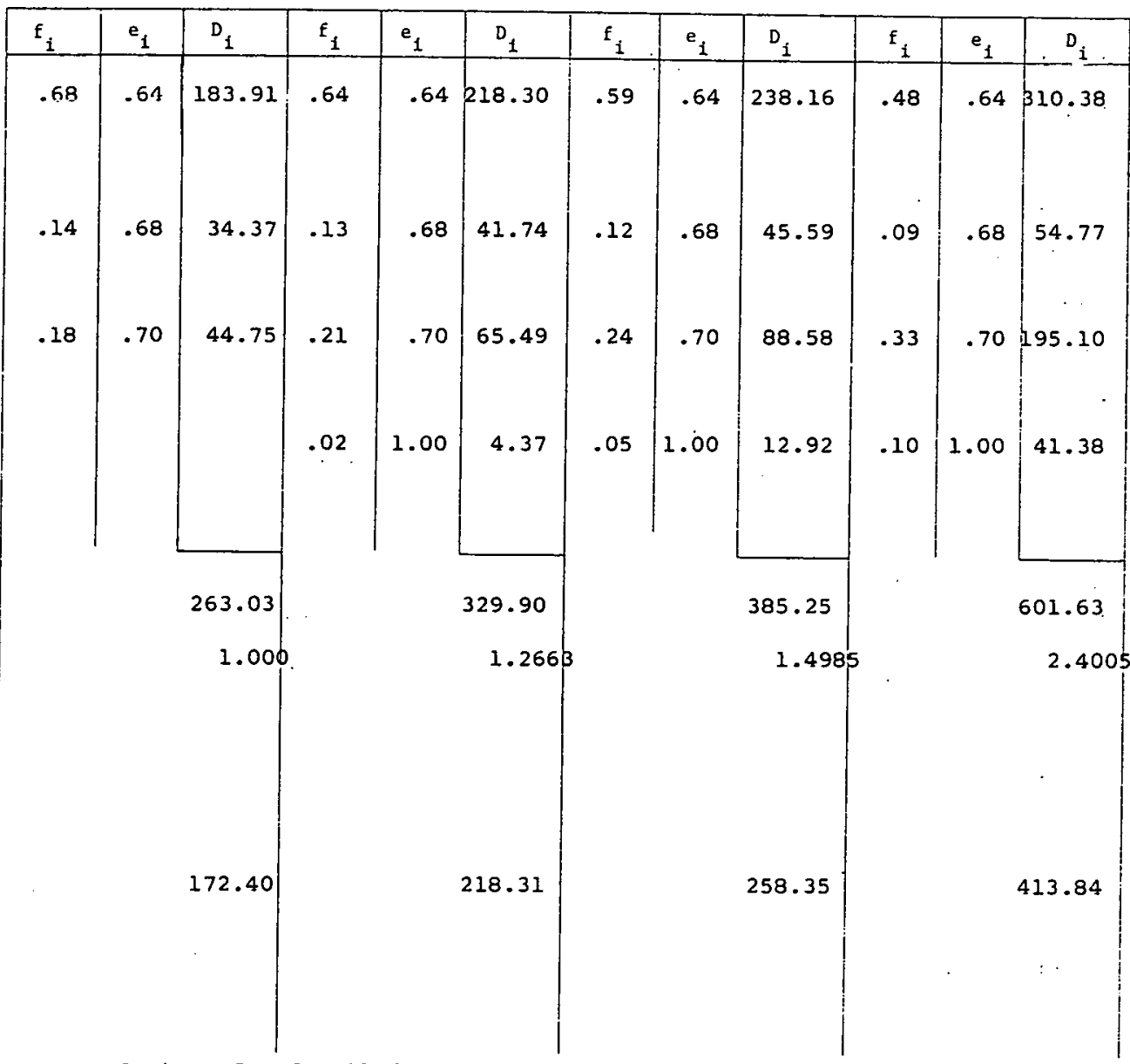

REF ERENCE TECHNOLOGIES: Burner devices for fossil fuels, electric.

DATA SOURCES: $\mathrm{D}_{i}$ (for 1975): Industrial process Heat demand represents the balance of. unaccounted fuels to the industrial sector. Energy demand in the industrial sector is computed as the product of

$\left[\frac{\text { ENERGY DEMAND BY INDUSTRY }}{\text { S VALUE ADDED }}\right]_{\text {ESC }} \mathrm{X} \cdot \quad$ [VALUE ADDED] $]_{\text {TVA }}$

where elielyy per dollar value added in the East south central census region (ESC) is assumed to approximate that in the TVA region. TVA fuel fractions are asgumed to be the same as Tennessee.

$e_{i}: \quad$ Ref. (6), p. 18 .

$f_{i}:$

Apparent fractions based on 1975 data.

BASIS OF PROJECTIONS :

A $2.6 \%$ growth rate from 1975 to 2000 in the U.S. is based on two assumptions: 1) The average GNP growth rate in real dollars will be $3.2 \%$ between 1975 and 2000 ; 2) The ratio of energy consumed by indistrir to ors w 111 continue declining at the liale ulserved historically between 1960 and 1975 . The $2.6 \%$ national growth rate is increased to $4.8 \%$ from 1975 to $1980,3.4 \%$ from 1980 to 1985 . and $3.2 \%$ thereafter for the TVA region. This is uased on the ratio of TVA to U.S. manufacturing earnings in the projected year divided by the TVA to U.S. earnings in 1970 (Ref. 17).. 
DIRECT FUEL USE

Methane

Jet Fuel

Gasoline

Distillate ofl

Residual ofl

Coal

Other

ELECTRISITY

TOTAL FUEL DEMAND, D, $10^{12} \mathrm{BCu}$

BASIS, Multiple of 1975

SATIIRATION, S,

BASIC ENERGY DEMAND, E, $10^{12} \mathrm{BCU}$

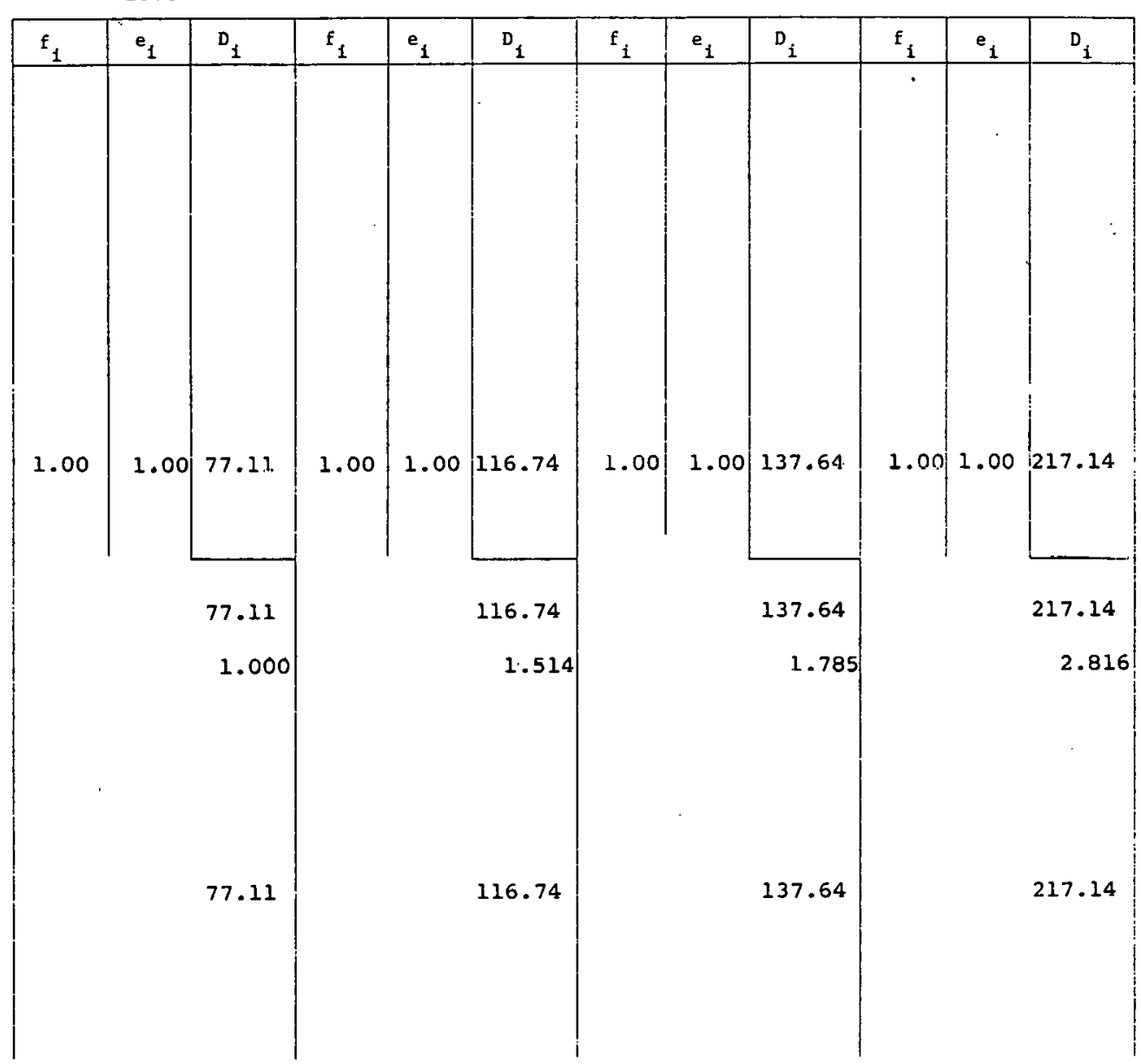

REFERENCE TECHNOLOGIES: AC inäuction motor.

DATA SOURCES: $D_{i}$ (for 1975): Adjusted to pluvlde the balapre nf unaccounted electric demand as reported by TVA.

$e_{i}$ and $f_{i}: \quad$ Taken as unity since there is unly one cnergy source employed.

BASIS OF PROJECTIONS: Elertricity sales projected to 1985 as reported by TVA. sales to distributors projerted at $5.5 \%$ from 1985 to 2000 . Sales direct to industry from 1985 to 2000 as reported by TVA. 
PROJECTED FUEL MIX

Region: TENNESSEE VALLEY AUTHORITY

DIRECT FUEL USE

Methane

Jet Fuel

Gasoline

Distillate oil

Residual ofl

Coal

other

ELECTRICITY

TOTAL FUEL DEMAND, $D$, $10^{12}$ Btu

BASIS. Multiple of 1975

SATURATION, S,

BASIC ENERGY DEMAND, E, $10^{12}$ Btu

UNIT BASIC DEMAND, $\varepsilon_{u}$,

1980 1985

Caregory: Petrochemical Feedstocks, Asphalt, \& Road Oil 2000

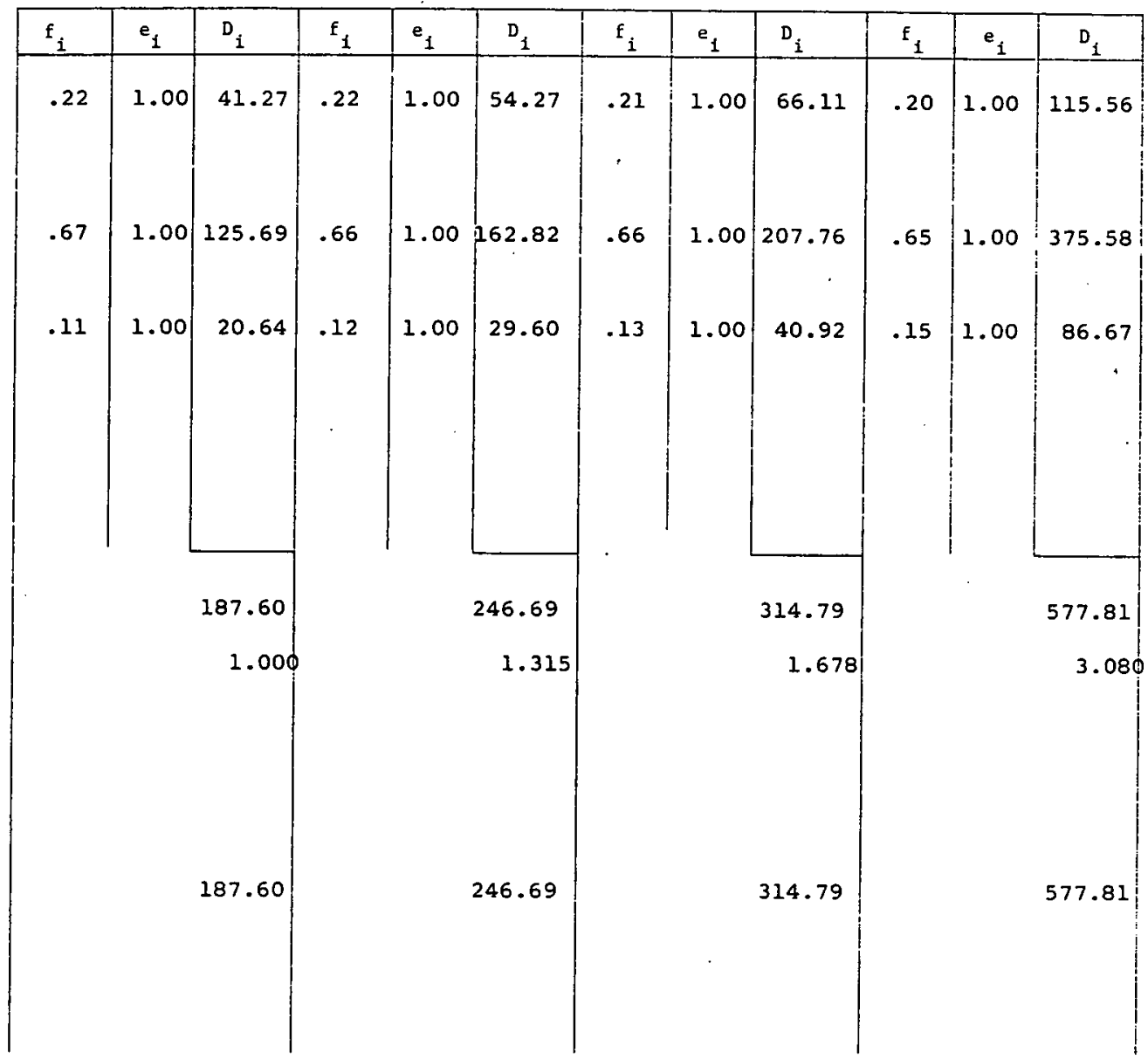

REFERENCE TECHNOLOGIES: Undefined.

DATA SOURCES: $D_{i}$ (for 1975): Regional energy demand is proportional to regional value added relative to U.S. value added in SIC 28 .

$$
\begin{aligned}
& e_{i}: \\
& f_{i}:
\end{aligned}
$$

These are taken as unity since the resources are used for their material input rather then their energy content.

Apparent fractions from the East South Central Census Region (Ref. 30).

BASIS OF PROJECTIONS:

The basic energy demand derived for 1975 is escalated in proportion to projected U.S. output in SIC 28 from the BNL input-output model assuming a 3.28 GNP growth rate (Ref. 40 ). U.S. output in SIC 28 is regionalized to the TVA service area based on projected regional earnings in chemicals and allied products. 


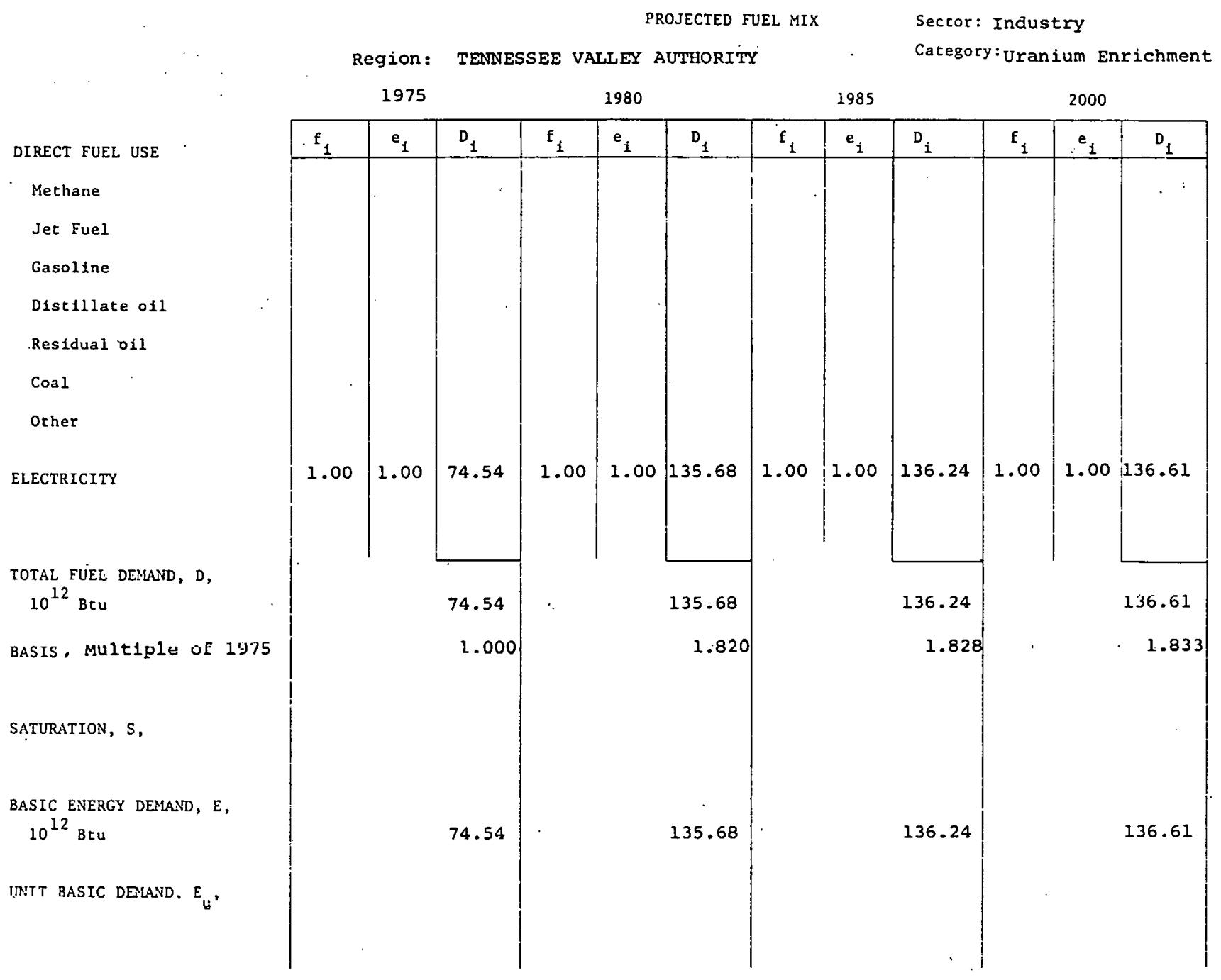

REFEREPCE TECHDOLOGIES: Gaseous diffusion.

DATA soURchs: $D_{i}$ (for 1975): Electricity sạles data as reported by TVA.

$e_{i}$ and $f_{i}$ : Taken as unity since there is only one energy source employed.

BASIS OF PROJECTIONS: Electricity sales projections ás repurted uY TVA. 


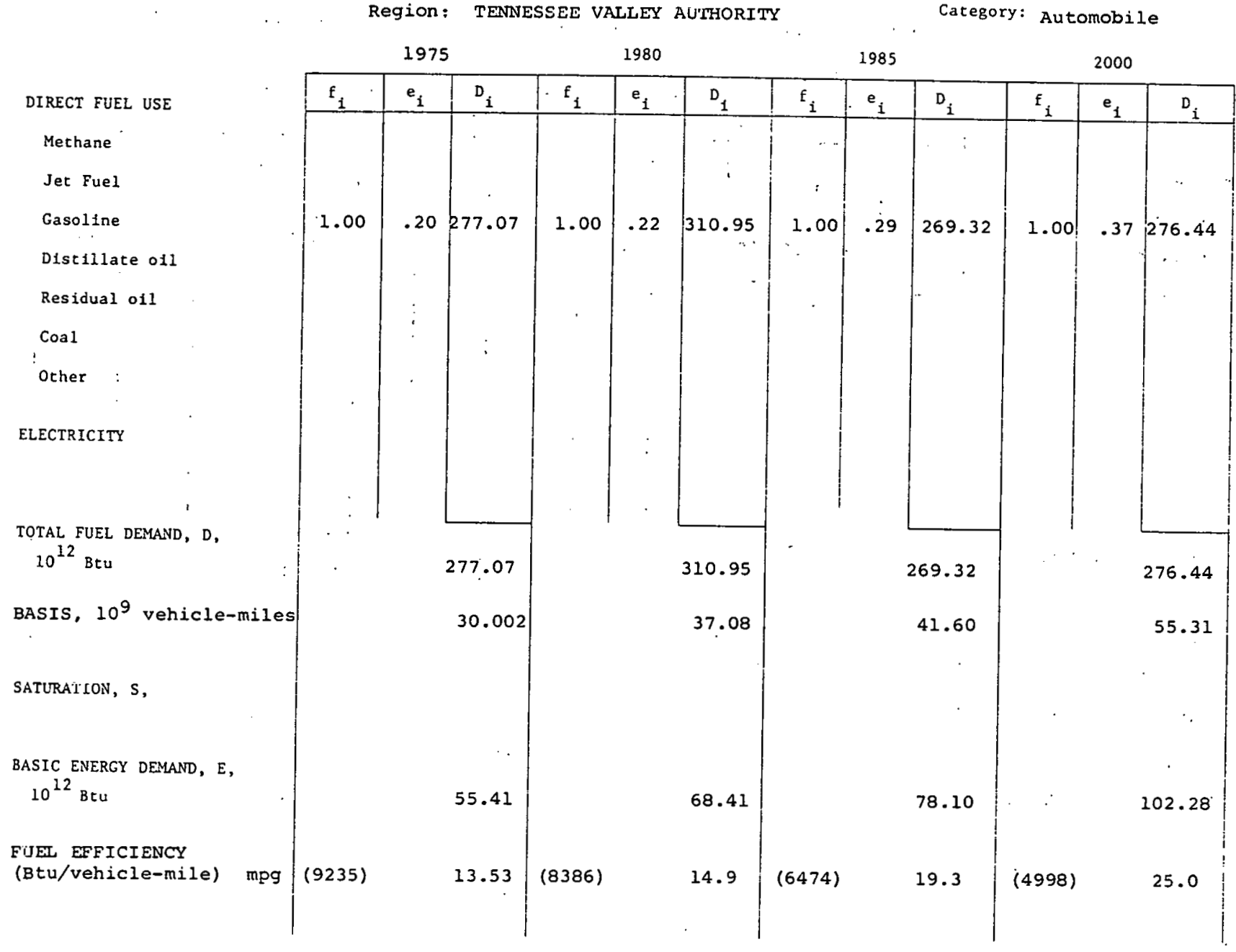

REFERENCE TECHNOLOGIES: Internal combustion engine.

DATA SOURCES: $D_{i}$ and $E_{i}$ (for 1975): Reference 10 .

$e_{i}$ : $\quad$ Estimated at $20 \%$ for 1975 .

BASIS OF PROJECTIONS:

Fuel efficiency of new model cars reduced by $10 \%$ from that mandated by the Energy Policy and Conservation Act (Ref. 20), Flept econom: delived from age distribution of vehicles (Ref. 19), vehicle-miles per model year, and fuel economy per model year. Vehicle-miles per year assumed to remain at the 1975 level of $10,800 \mathrm{milcs} / \mathrm{vehiele}$ ( $\mathrm{H}$ HW estimate corrected for reregistered and scrapped vehicles). The ratio of vehicles to driving age population is projected to increase in proportion to growth in the U.S. fleet, from .61 in 1975 to .85 in 2000 . . 


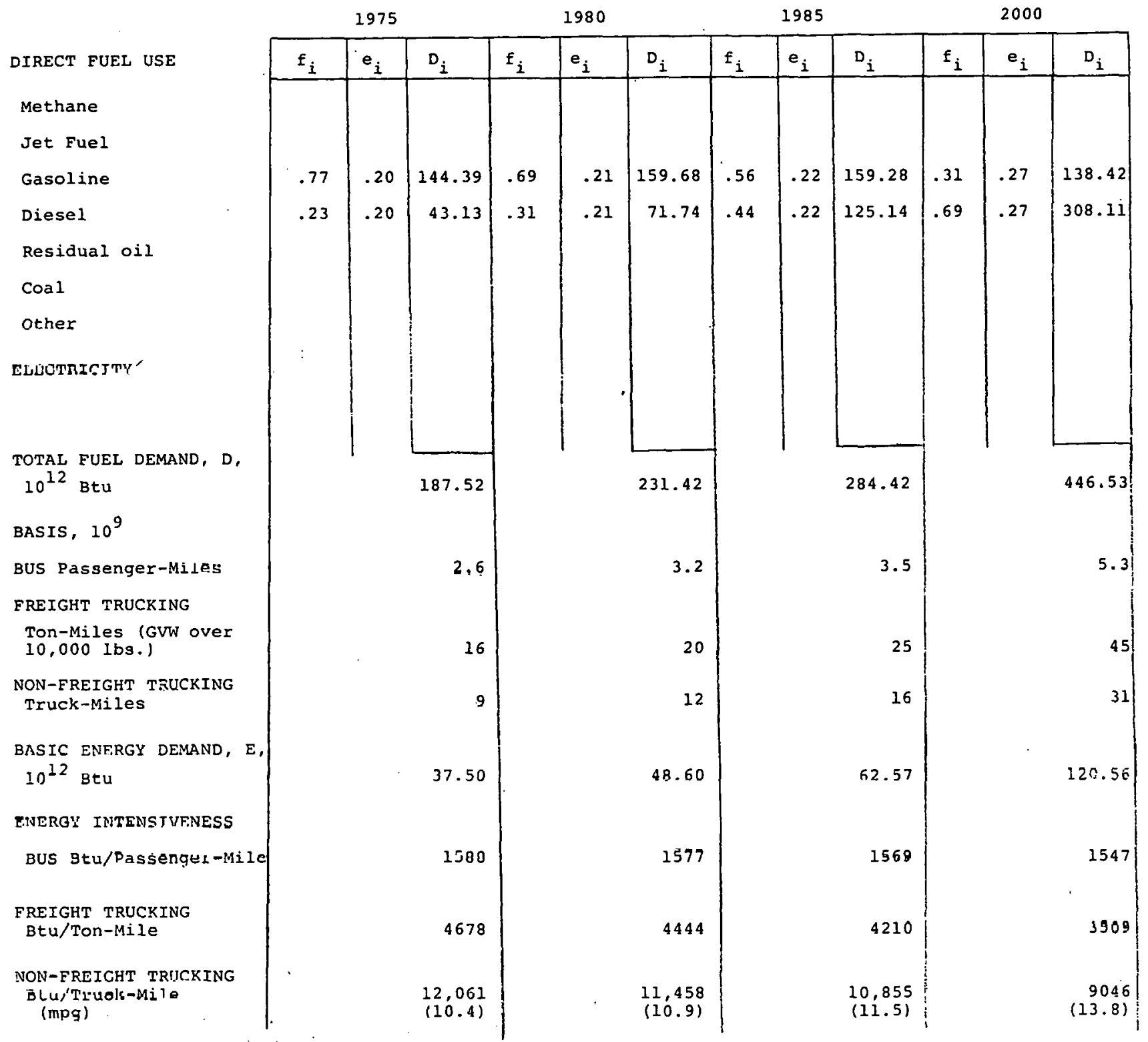

KEFEREISCD TDGHIOARTFS: Internal combustion engine.

DATA SOURCES: $D_{i}$ and $f_{i}$ (for 1975):

$e_{i}:$

Number of trucks per state from FHWA (Ref. 10); number of trucks Per state within TVA region proportional to TVA population per state. Miles per truck held at 1373 levels. Ton-miles per truck And pcroont of gascline versus diesel trucks derived from r'EA data (Ref. 39). Percent uf truoke by wright olass pxtrapolated from 1967 and 1972 Census of Transportation data (Ref. 44 ). Bus passenger-miles proportional to population.

Miles per gallon for non-freight trucking, BNL estimate. Btu/tonmile from Ref. 39 .

BASIS OF PROJECTIONS: Freight trucking ton-miles escaldiel at the same rate as GNP, 3.28 , adjusted by total regional earnings. Non-freight trucking truck-miles escalated at 6.18 from 1975 to $1980 ; 5$. 38 from 1980 to 1985 , and 4.68 from 1985 to 2000 . These regional growth rates were derived from national projections (Ref. 39) adjusted by total regional earnings. The energy intensiveness of freight trucking, Btu/ton-mile, and non-freight trucking, Btu/truck-mile, are reduced by 258 over the reference years. 


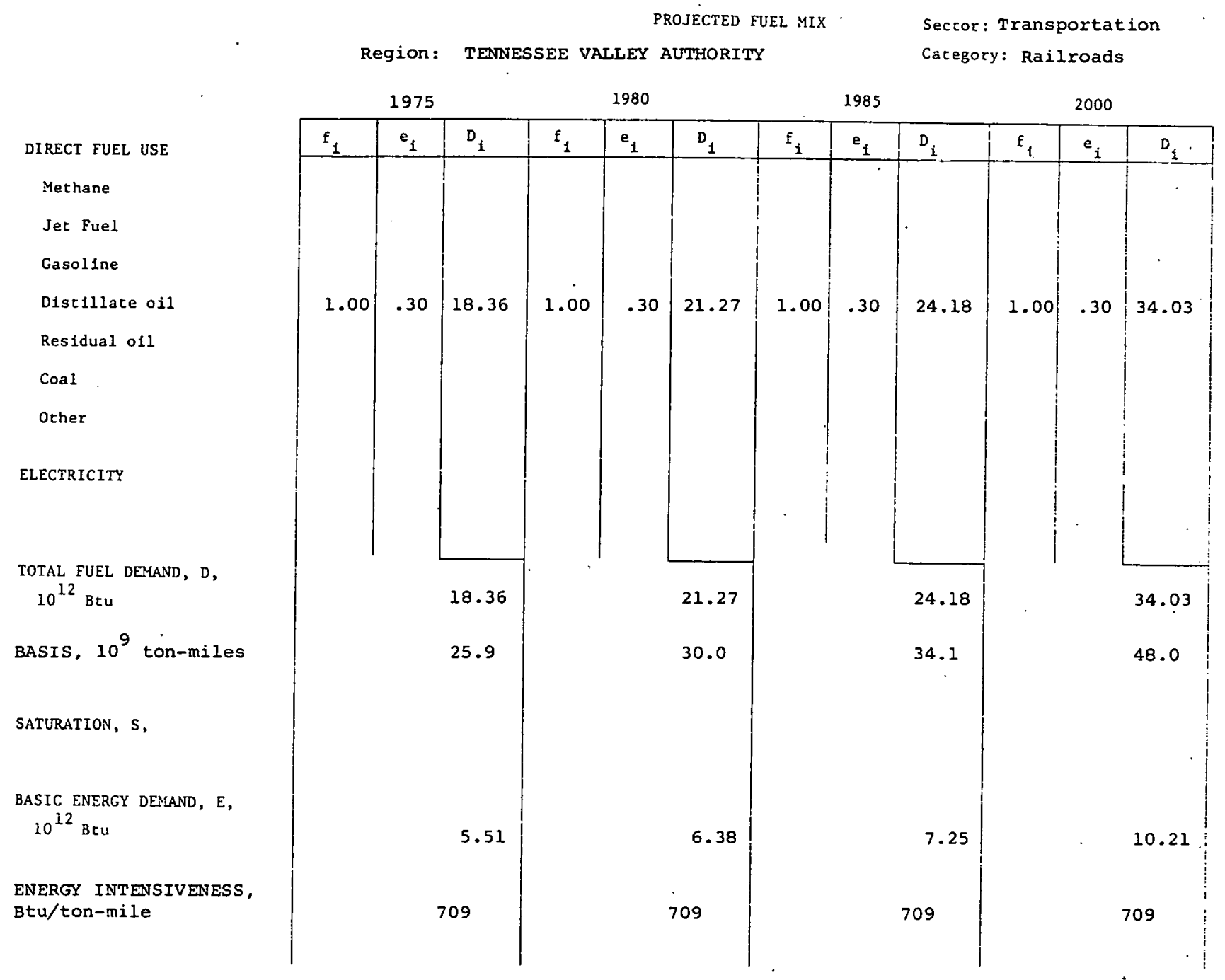

REFERENCE TECHNOLOGIES: Diesel engine.

DATA SOURCES: $D_{i}$ (for 1975): Diesel fuel consumption derived from Bureau of Mines data (Ref. 11). $e_{i}$ : $\quad$ Estimated at $30 \%$.

BASIS OF PROJECTIONS: Diesel fuel escalated at the U.S. growth rate (2\%) arjustcd by Lie ratıo of TVA to U.S. total earnixys in the projected year divided by the TVA to U.S. total earnings in 1970 (Reference 17 and BNL estimates). 
DIRECT FUEL USE

Mechane

Jet Fuel

Gasoline

Distillate oil

Residual oll

Coal

other

ELLUIAIEIT'

TOTAL FUEL DEMAND, D, $10^{12}$ Btu

BASIS $10^{9}$, passenger-

SATURATION, $S$,

BASIC ENERGY DEMAND, E, $10^{12} \mathrm{BCu}$

ENERGY INTENSIV ENTES9, Btu/passenger-mile

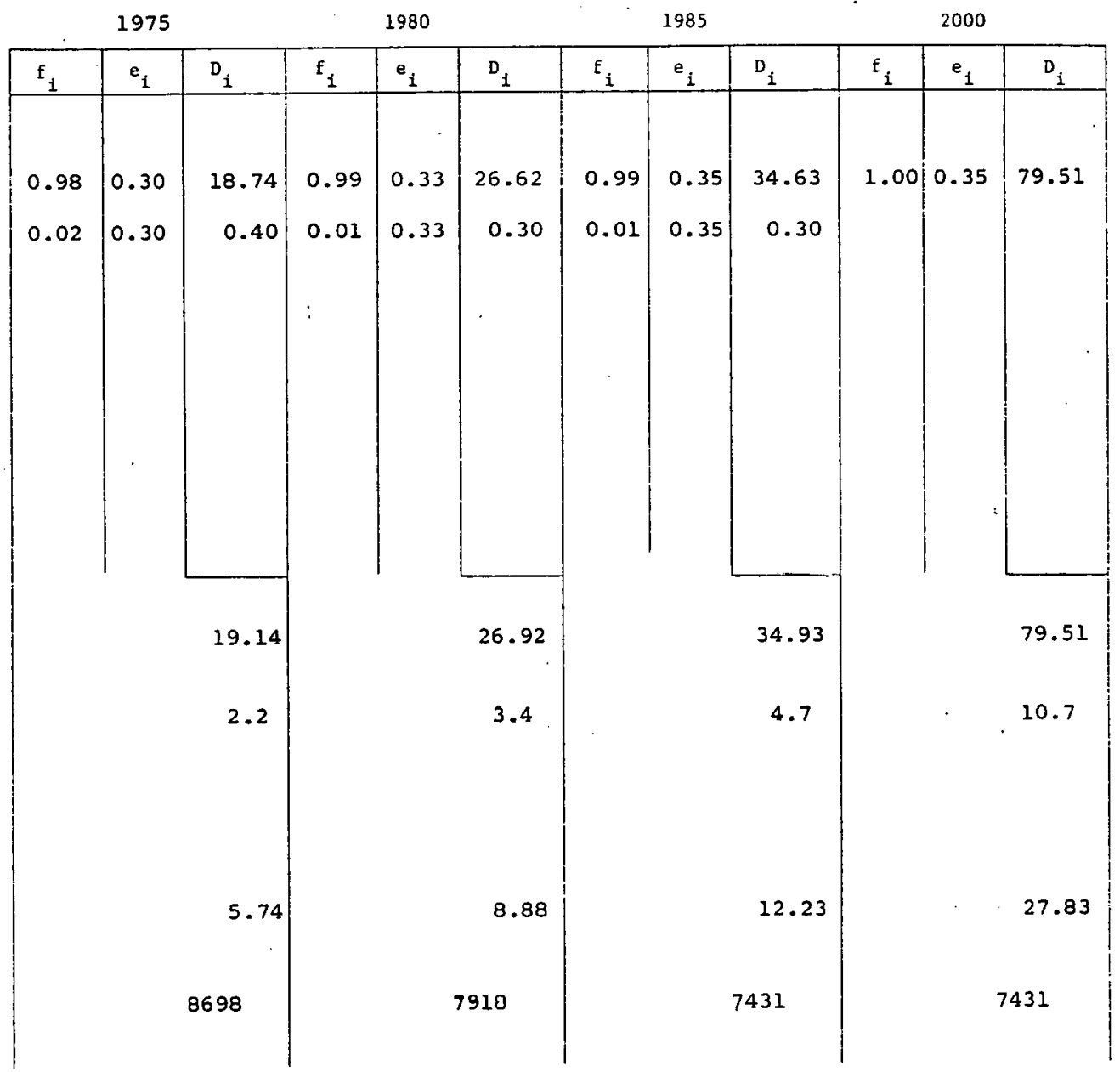

RES FRFNCF, TEÇHNOLOGIES: Aireraft gas turbines (Lurbofan). DATA SOURCES: $D_{i}$ (for 1975): Jet fuel consumptlul in Tonnoseop determined from Bureau of Mines data.
Aviation gasoline consumption in Tennessee from Ret. (1U'). Oet. fual and aviation gasoline consumption in TVA region (excluding Tennessee) determined from a survey of commercial airports.

$$
{ }^{\theta_{i}}{ }_{i}:
$$

BASIS OF PROTECTIONS:
Estimated efriciencies for aircraft gas tụrbines.

Apparont fraction based on $14 \%$ dala.

U.S. domestic and intemational passenger-miles from ATAA (kef. 34 and 35 ) adjusted to includc general aviation. TVA air passenger-miles proportional to C.S. air passenger-mile projections, adjusted upwarl by the ratio of TVA to U.S. total earnings projections (Ref. 17) normalized to 1970 . 
P.ROJECTED FUEL MIX

Region: TENNESSEE VALLEY AUTHORITY
Sector: Transportation

Category: Ships

DIRECT FUEL USE

Methane

Jet Fue.]

Gasoline

Distillate oil

Residual ofl

Coal

Other

ELECTRICITY

TOTAL FUEL DEMAND, D, $10^{12} \mathrm{BCu}$

BASIS, $10^{9}$ Ton-Miles

SATURATION, S,

BASIC ENERGY DEMAND, E, $10^{12}$ Btu

ENERGY INTENSIVENESS Btu/Ton-Mile

1975

1980

1985

2000

\begin{tabular}{|c|c|c|c|c|c|c|c|c|c|c|c|}
\hline & & \\
\hline $\mathbf{f}_{\mathbf{i}}$ & $e_{i}$ & $D_{1}$ & $\mathrm{f}_{1}$ & $e_{1}$ & $\mathrm{D}_{1}$ & $f_{i}$ & $\mathrm{e}_{i}$ & $\mathrm{D}_{\mathrm{i}}$ & $f_{i}$ & $e_{i}$ & $D_{i}$ \\
\hline 1 & & & - & & & , & . & & . & & \\
\hline .18 & .20 & 3.23 & .20 & .20 & 4.04 & .21 & .20 & 5.06 & .23 & .20 & 7.88 \\
\hline .82 & .20 & 14.34 & .80 & .20 & 16.62 & .79 & .20 & 18.88 & .77 & .20 & 26.59 \\
\hline & & 17.57 & & & 20.66 & $\cdot \cdot$ & & 23.94 & & & 34.47 \\
\hline & & 25.3 & & & 29.3 & & & 33.3 & & & 46.9 \\
\hline & & & : & & & & & : & . & & \\
\hline & & 3.51 & & & 4.13 & & & 4.79 & & & 6.89 \\
\hline & & 567 & & & 567 & & & 567 & & & 567 \\
\hline
\end{tabular}

REFERENCE TECHNOLOGIES: Steam and internal combustion engines. DATA SOURCES: $D_{i}$ (for 1975): Fuel oil consumption derived from Bureau of Mines data (Ref. 11).
Gasoline consumption from FHWA data (Ref. 10).

$$
e_{i}:
$$

BASIS OF PROJECTIONS
Estimated at $20 \%$.

Appazont Eraction based on 1975 data.

Gasoline escalated at $4.6 \%$ through 1985 bascd on historical data and reduced to $3 \%$ thereafter. Fuel oil escalated at the U.S. growth rate (2\%) adjusted by the ratio of TVA to U.S. total earnings, in the projected year divided by the TVA to U.S. total earnings in 1970 (Ref. 17 and 23). 


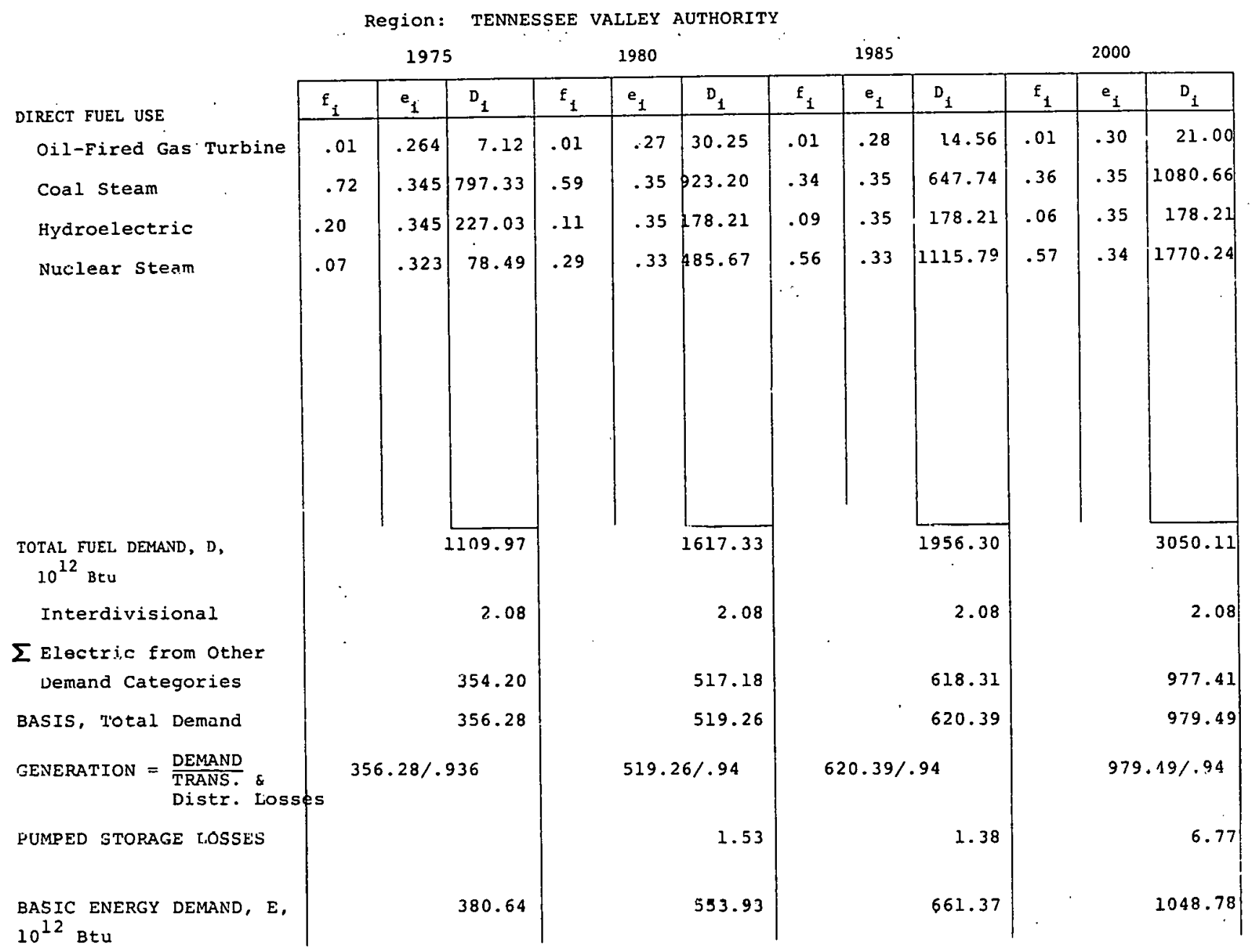

RELEREMG TFKHNOLOGIES: Coal is consumed in steam electric plants with no topping cycle. Oil is consumec in gas turbine peakluy units. Nurlear fuel is consumed in light water reactors.

DATA SOURCES: $D_{i}$ for (1975) The basic energy demand for electricity is obtained from the summation of electrical demands in all other demand categories adjusted to include transmission, distribution, and pumped storage losses. Total demand include purchases and sales to other utilities and interchange power deliveries and receipts.

$E_{i}$ : Oil-fired gas turbine held in proportion to hata as reported by TVA. Hydro and nuclear steam as reported by TVA. Coal-steam meets romalnder of loar in 1979.

Coal steam-electric, oll fired gzs-turhine and nuclear steam plants convertcd at ąn average heat rate of $9880 \mathrm{Btu} / \mathrm{KWh}$, l2ybu Btu/kWh and $10570 \mathrm{Btu} /$ $\mathrm{KWh}$, respectively; as reported by TVA in the 1976 Power Annual Report. Hydrawlitirio outnit is converted to theoretical energy inputs bayed on the equivalent coal-steam electrlic heat ratw

BASIS OF PROJECTIONS :

The basic energy demand for electricity is obtained from the summation of electric demands in all other demand categories adjusted to include transmission, distribution, and pumped storage losses. The fraction of the basic energy demand satisfied by gas turhine units is held in proportion to data projected by TVA. Hydro and pumped storage as projected by TVA. In 1980, LWR as projected Ly TVA; coal-ateam meets remainder of projected load. In 1985, nuclear capacity reduced from TVA projectlons by $1250 \mathrm{MW}$; coal-steam meets remainder of projected load. In 2000, nuclear capacity reduced from TVA projections by $5000 \mathrm{MW}$; coal-steam meets remainder of projected load. 